\section{OAK RIDGE} NATIONAL LABORATORY

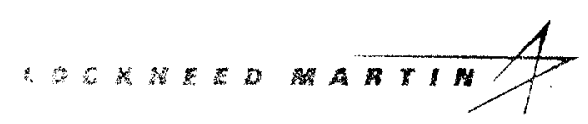

\section{LIFE CYCle ANAlysis FOR D\&D DECISION MAKING:}

DISPOSITION OF HANFORD RAILCARS

\author{
Katherine L. Yuracko \\ Michael I. Morris \\ Terry L. Hatmaker
}





\title{
LIFE CYCLE ANALYSIS FOR D\&D DECISION MAKING: DISPOSITION OF HANFORD RAILCARS
}

\author{
Katherine L. Yuracko \\ Michael I. Morris \\ Terry L. Hatmaker
}

November 1999

\author{
Prepared for the \\ Deactivation and Decommissioning Focus Area \\ of the \\ U.S. Department of Energy \\ Orfice of Environmental Management \\ Office of Science and Technology
}

Prepared by the

Center for Life Cycle Analysis

Oak Ridge National Laboratory

Oak Ridge, Tennessee 37831 managed by

Lockheed Martin Energy Research Corp.

for the U.S. Department of Energy

under contract DE- $\Lambda$ C05-96OR22464 
$\Rightarrow$

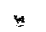




\section{CONTENTS}

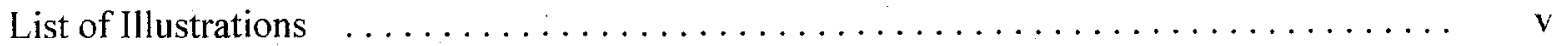

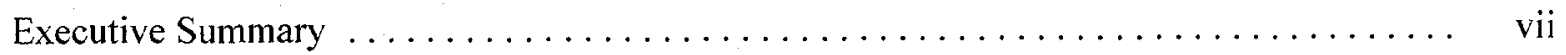

List of Abbreviations and Acronyms $\ldots \ldots \ldots \ldots \ldots \ldots \ldots \ldots \ldots \ldots \ldots \ldots \ldots \ldots \ldots$

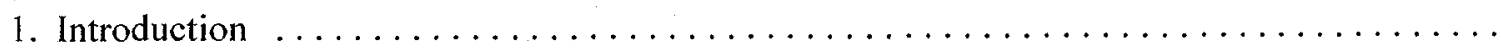
1

2. The Life Cycle Analysis Process $\ldots \ldots \ldots \ldots \ldots \ldots \ldots \ldots \ldots \ldots \ldots \ldots \ldots \ldots \ldots$

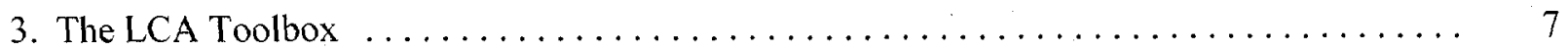

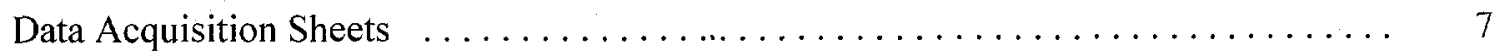

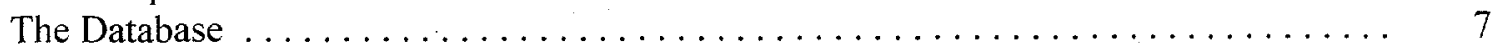

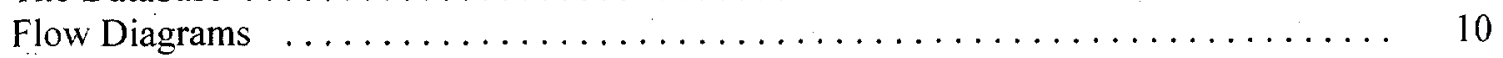

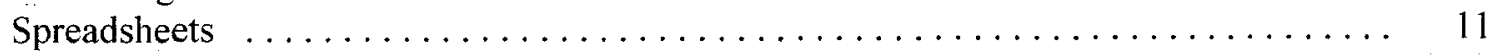

Cost Spreadsheets and Uncertainty and Sensitivity Analysis .............. 11

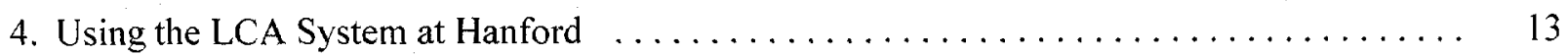

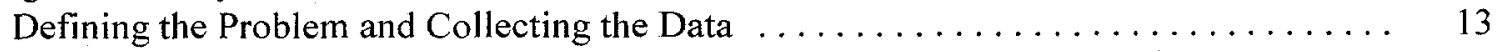

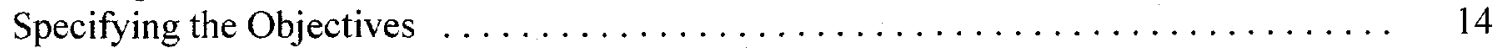

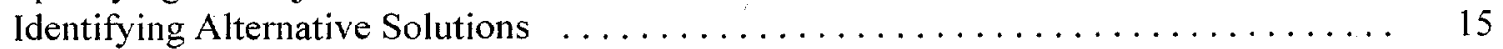

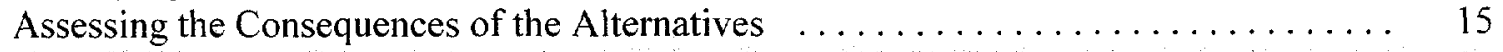

Results of the Analysis $\ldots \ldots \ldots \ldots \ldots \ldots \ldots \ldots \ldots \ldots \ldots \ldots \ldots \ldots \ldots \ldots \ldots \ldots \ldots \ldots \ldots, 22$

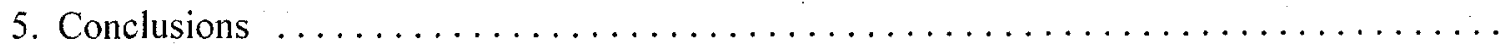
27

Appendices

A. Photographs of Railcars Analyzed at Hanford $\ldots \ldots \ldots \ldots \ldots \ldots \ldots \ldots \ldots \ldots \ldots \ldots$

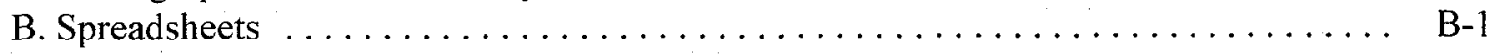

C. Uncertainty Analysis $\ldots \ldots \ldots \ldots \ldots \ldots \ldots \ldots \ldots \ldots \ldots \ldots \ldots \ldots \ldots \ldots \ldots \ldots \ldots \ldots$ 
-

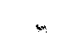




\section{ILLUSTRATIONS}

Figures

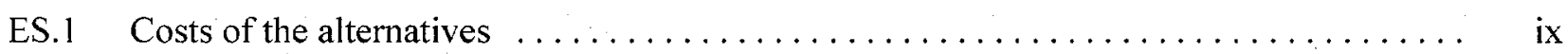

ES.2 Material flow diagram for the preferred alternative $\ldots \ldots \ldots \ldots \ldots \ldots \ldots \ldots \ldots$ ix

ES.3 Expected cost savings from providing the cars to the CRO relative to baseline disposal .. $\quad \mathrm{x}$

ES.4 Providing railcars to the CRO provides cost savings and other benefits, but at some

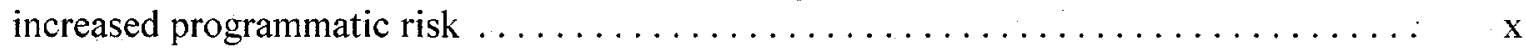

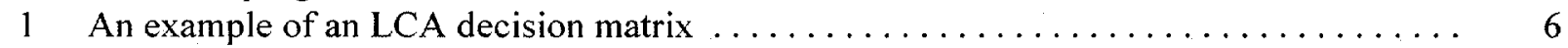

2 A screenshot of the ORNL LCA database $\ldots \ldots \ldots \ldots \ldots \ldots \ldots \ldots \ldots \ldots \ldots$

3 A screenshot of typical source material incorporated into the LCA database . . . . . . . 9

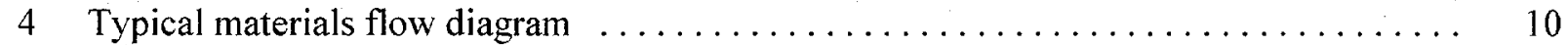

5 A frequency chart representing all possible outcomes for a disposal alternative $\ldots \ldots \ldots 12$

6 A frequency chart representing the cost savings from recycling relative to disposal $\ldots . . \quad 12$

$7 \quad$ One of the Hanford locomotives scheduled for disposition $\ldots \ldots \ldots \ldots \ldots \ldots \ldots \ldots \ldots$

8 Material flow diagrams for options 1A and 1B: disposal $\ldots \ldots \ldots \ldots \ldots \ldots \ldots \ldots$

9 Material flow diagram for option 2: off-site decontamination and release

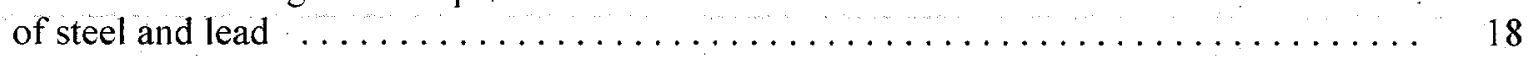

10 Material flow diagram for option 3: CRO on-site decontamination and sale of railcars, with off-site processing of remaining railcars for.sale as scrap or melt for shield blocks .. $\quad 19$

11 Material flow diagram for option 4: CRO on-site decontamination and sale of railcars,

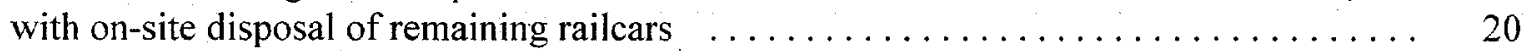

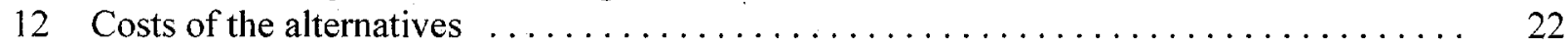

13 Sensitivity analysis for comparison of option 3 with option $1 \mathrm{~A} \ldots \ldots \ldots \ldots \ldots \ldots .23$

14 Sensitivity analysis for comparison of option 3 with option $1 \mathrm{~B} \ldots \ldots \ldots \ldots \ldots \ldots 23$

15 Expected cost savings from providing the cars to the CRO relative to baseline disposal .. 24

16 Expected cost savings from providing the cars to the CRO relative to baseline disposal .. 24

17 Expected volumes of waste prevented by providing the railcars to the CRO relative to

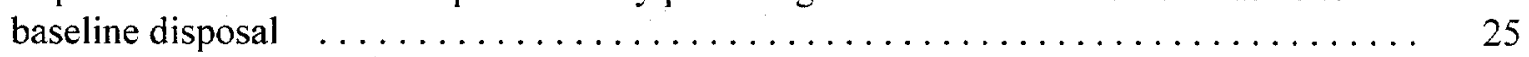

18 Providing railcars to the CRO provides cost savings and other benefits, but at some

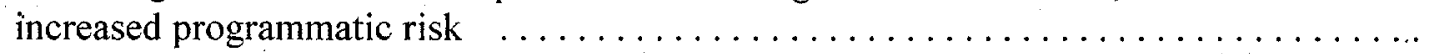

\section{Tables}

1 Expected waste generated under each alternative $\ldots \ldots \ldots \ldots \ldots \ldots \ldots \ldots \ldots$

2 Summary of health, environmental, programmatic, and institutional impacts

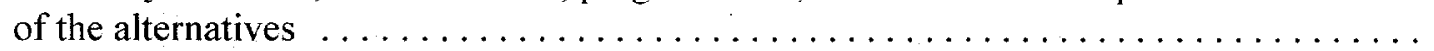

\section{Sidebars}

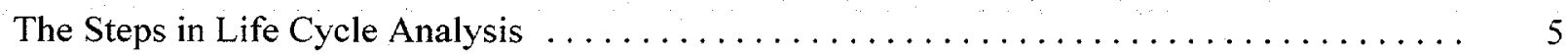

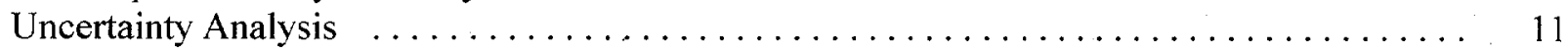

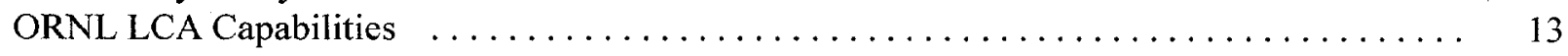




\section{EXECUTIVE SUMMARY}

This report summarizes a joint venture between the U.S. Department of Energy (DOE) Deactivation and Decommissioning Focus Area and the Oak Ridge Operations Assets Utilization (AU) Facilities and Materials Reuse Division (FMRD) in its role as the DOE National Center of Excellence for Metals Recycle (NMR), to better address problems in the DOE complex. This task was initially developed to meet a request from the Richland Operations Office (RL) to AU FMRD for assistance in analyzing equipment reuse and metals recycling opportunities at $\mathrm{RL}$, utilizing expertise and experience related to life cycle analysis (LCA), technology, and planning.

Oak Ridge National Laboratory (ORNL) has developed an LCA system to assist DOE in identifying and analyzing opportunities for equipment and materials reuse and recycle. This report presents the use of the LCA system to identify and analyze methods for disposition of surplus railcars at the Hanford site. Alternative possible disposition pathways were evaluated for their financial, health and safety, environmental, programmatic, and institutional impacts; and a preferred disposition pathway was identified.

The Hanford railcars evaluated in this case study fall into eight classes:

1-2. flat $\mathrm{BN}$ and flat $\mathrm{PX}$ - standard railroad flatcars;

3. well $10 \mathrm{~B}-$ a drop-center railcar that has a steel box containing three lead fuel casks and that was used to haul fuel;

4. cask $10 \mathrm{~B}-\mathrm{a}$ flatcar that has a steel box containing one large lead fuel cask and that was used to haul fuel;

5. tank $10 \mathrm{H}$ - a carbon steel tank car, used to haul radioactive liquid;

6. tank 10A - a double-walled stainless steel tank car, used to haul radioactive liquid;

7. car trucks - sets of wheels, with each car having two sets; and

8. locomotives-two locomotives.

This analysis developed and evaluated five disposition alternatives for each of the eight classes of railcars:

- Option 1: Disposal

- Option 1A (Baseline Approach) - In this alternative the primary components of the railcars, steel and lead, would be separated, processed, packaged, and buried on-site at the low-level waste (LLW) and mixed waste (MW) disposal facilities, respectively.

- Option $1 B$ - In this alternative the cask and well cars would be disposed of intact at the on-site MW disposal facility. All other cars would be disposed of in the LLW disposal facility.

- Option 2: Off-site decontamination and release of steel and lead - In this alternative the cars would be transported to a Nuclear Regulatory Commission (NRC)-licensed facility, cut up, and decontaminated as appropriate. A large percentage of the steel and all of the lead would then be sold as scrap metal, with a smaller percentage of the steel melted for shield block.

- Option 3: Community Reuse Organization (CRO) decontamination and sale of railcars where cost-effective, with processing of the remaining railcars as described in option 2 - In this 
alternative the cars would be provided to a CRO. The CRO (or its qualified agent) would decontaminate the cars and sell them for reuse where feasible. Cars that could not be costeffectively decontaminated for reuse would be sent to an NRC-licensed facility for processing as described in option 2.

- Option 4: CRO decontamination and sale of railcars where cost-effective, with disposal of the remaining railcars as described in option $1 \mathrm{~A}$ - In this alternative the cars would be provided to a CRO. The CRO (or its qualified agent) would decontaminate the cars and sell them for reuse where feasible. Cars that could not be cost-effectively decontaminated for reuse would be buried on-site as described in disposal option $1 \mathrm{~A}$.

The results of the cost analysis, summarized in Fig. ES.1, show that the most cost-effective option is option 3: providing the railcars to the CRO for decontamination and sale where feasible. Railcars that are too contaminated for sale would be transported to an NRC-licensed facility, cut up, and decontaminated. A large percentage of the steel and all of the lead would then be sold as scrap metal, with a smaller percentage of the steel melted for shield block. This process for dispositioning the railcars is depicted in Fig. ES.2.

Because of the large uncertainties in the underlying variables, uncertainty and sensitivity analyses were performed to provide a truer picture of project costs. Rather than rely on single-point estimates, we replaced the uncertain variables in our cost model with a range of possible values. Each value in the range has a probability of occurrence. A simulation is then run, simulating thousands of potential outcomes by running thousands of trials. The result is a frequency chart that represents all of the possible outcomes (see Fig. ES.3). Using this frequency chart, decision makers can determine not only the range of possible outcomes but also the likelihood of occurrence.

To implement this, reasonable ranges and probability distributions were determined for all input parameters. The greatest emphasis was placed on those variables revealed, through sensitivity analysis, to have the greatest influence on the results. Sensitivity analysis reveals that two factors drive the results: the number of cars decontaminated and sold by the CRO; and the cost of LLW disposal. Therefore, we evaluated the worst case, that the CRO is not able to decontaminate for reuse any of the cars and must send all of them to a vendor for processing. We varied the disposal cost over a range from $\$ 15$ to $\$ 35 / \mathrm{ft}^{3}$. Other parameters were varied in similar manner. Based on this uncertainty analysis, option 3, CRO with off-site vendor processing, is expected to save between $\$ 2.6$ and $\$ 4.6$ million relative to disposal option $1 \mathrm{~A}$ (at an $80 \%$ confidence level).

In addition to the cost analysis, the alternatives were evaluated for the waste quantity generated, and their environmental, health and safety, programmatic, and institutional impacts. For example, relative to the baseline disposal option $1 \mathrm{~A}$, option 3 is expected to prevent disposal of between 1770 and 1950 tons of waste (at an $80 \%$ confidence level). The complete analysis is summarized in Fig. ES.4. Alternatives involving the CRO were considered to have higher programmatic risk than the other alternatives, primarily because of the first-of-a-kind nature of the venture. However, DOE believes the increased programmatic risk is more than offset by the expected cost savings and institutional benefits resulting from providing the railcars to the CRO. Overall, option 3, providing the railcars to the $\mathrm{CRO}$, is considered the preferred method for disposition of the railcars. 


\begin{tabular}{|c|c|c|c|c|c|c|c|c|c|}
\hline Alternative: & $\begin{array}{l}\text { Flat } \\
\text { BN } \\
\end{array}$ & $\begin{array}{l}\text { Flat } \\
\mathrm{PX}\end{array}$ & $\begin{array}{l}\text { Well } \\
10 \mathrm{~B} \\
\end{array}$ & $\begin{array}{c}\text { Cask } \\
10 \mathrm{~B} \\
\end{array}$ & $\begin{array}{c}\text { Tank } \\
10 \mathrm{H} \\
\end{array}$ & $\begin{array}{c}\text { Tank } \\
10 \mathrm{~A} \\
\end{array}$ & $\begin{array}{c}\text { Car } \\
\text { Trucks }\end{array}$ & Locomotive & Total \\
\hline Disposal: Separate LLW and MW & $\$ 311,000$ & $\$ 311.000$ & $\$ 5.638,000$ & $\$ 1,975,000$ & $\$ 474,000$ & $\$ 494,000$ & $\$ 987.000$ & $\$ 667.000$ & $\$ 10,857,000$ \\
\hline $\begin{array}{l}\text { Disposal: Well \& cask cars disposed as MW } \\
\text { remaining cars disposed as LLW }\end{array}$ & $\$ 311,000$ & $\$ 311,000$ & $\$ 12,893,000$ & $\$ 4,514,000$ & $\$ 474,000$ & $\$ 494,000$ & $\$ 987,000$ & $\$ 667,000$ & $\$ 20,652,000$ \\
\hline Off-Site Vendor Processing & $\$ 413.000$ & $\$ 292,000$ & $\$ 4.012 .000$ & $\$ 1,465.000$ & $\$ 278,000$ & $\$ 278,000$ & $\$ 2,267,000$ & $\$ 880,000$ & $\$ 9,885,000$ \\
\hline CRO \& Off-Site Vendor Processing & $\$ 143,000$ & $\$ 143,000$ & $\$ 4,105,000$ & $\$ 1,498,000$ & $\$ 124,000$ & $\$ 126,000$ & $\$ 646,000$ & $\$ 192,000$ & $\$ 6,976,000$ \\
\hline CRO \& On-Site Disposal & $\$ 164,000$ & $\$ 164,000$ & $\$ 5,638,000$ & $\$ 1,975,000$ & $\$ 141,000$ & $\$ 156,000$ & $\$ 702.000$ & $\$ 271,000$ & $\$ 9,209,000$ \\
\hline
\end{tabular}

Note: Totals do not include cost of construction of a facility for characterization of the railcars (est. cost $\$ 1.53 \mathrm{M}$, regardless of alternative)

Fig. ES.1. Costs of the alternatives. The most cost-effective method for disposition of the railcars is Community Reuse Organization (CRO) decontamination and sale of railcars where cost-effective, with processing of the remaining railcars by an off-site vendor for sale as scrap or melt for shield block.

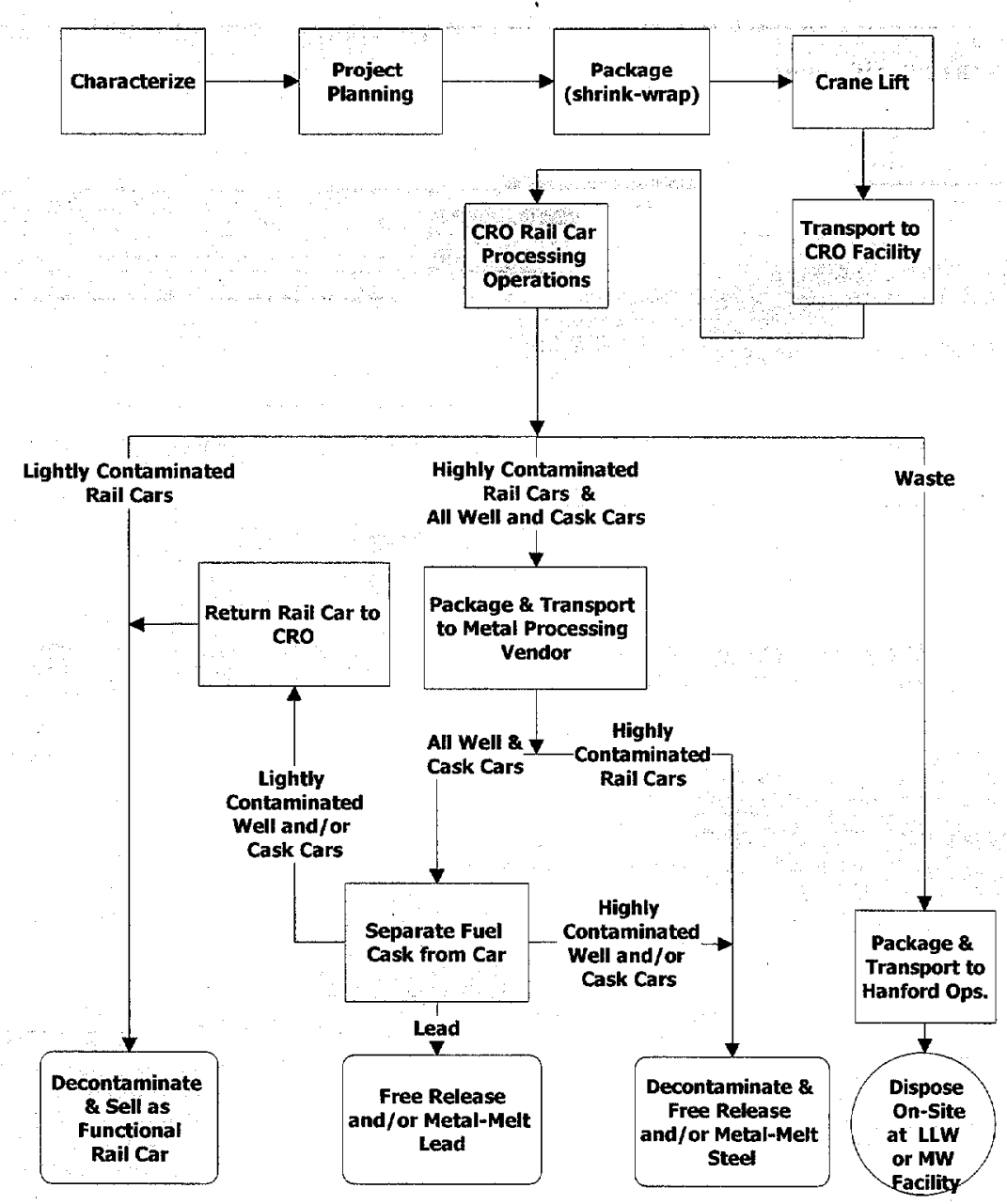

Fig. ES.2. Material flow diagram for the preferred alternative: CRO decontamination and sale of railcars where cost-effective, with processing of the remaining railcars by an off-site vendor for sale as scrap or melt for shield block. 


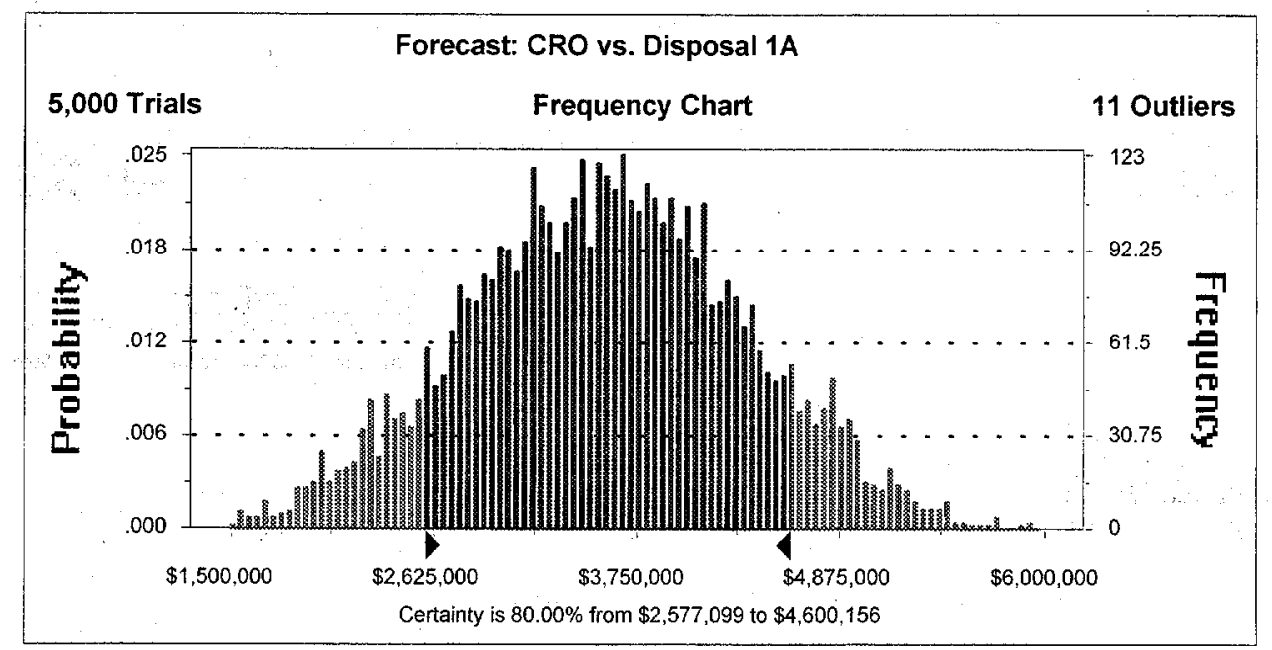

Fig. ES.3. Expected cost savings from providing the railcars to the CRO (option 3) relative to baseline disposal (option 1A) range from $\$ 2.6$ million to $\$ 4.6$ million (at an $80 \%$ confidence level).

\begin{tabular}{|c|c|c|c|c|c|c|}
\hline 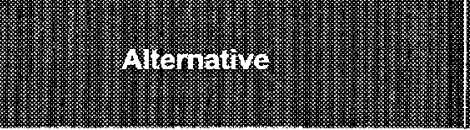 & 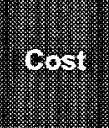 & 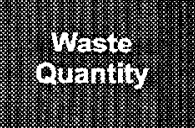 & 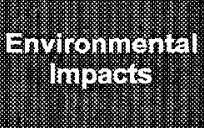 & arion & 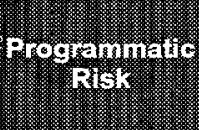 & $\log (\cos )$ \\
\hline $\begin{array}{l}\text { Disposal: Separate Low-Level } \\
\text { and Mixed Waste (Baseline) }\end{array}$ & $\$ 10.9 \mathrm{M}$ & $\begin{array}{r}4,700 \mathrm{ft}^{3} \mathrm{MW} \\
130,000 \mathrm{ft}^{3} \text { LLW }\end{array}$ & & & & \\
\hline $\begin{array}{l}\text { Disposal: Well \& Cask Cars Disposed } \\
\text { as MW, All Other Cars Disposed as LLW }\end{array}$ & $\$ 20.7 \mathrm{M}$ & $\begin{array}{l}78,000 \mathrm{ft}^{3} \mathrm{MW} \\
59,000 \mathrm{ft}^{3} \mathrm{LLW}\end{array}$ & & & & \\
\hline $\begin{array}{l}\text { Off-Site Vendor Processing, } \\
\text { Release as Scrap or Shieid Block }\end{array}$ & $\$ 9.9 \mathrm{M}$ & $\begin{array}{c}240 \mathrm{ft}^{3} \mathrm{MW} \\
6,600 \mathrm{ft}^{3} \mathrm{LLW}\end{array}$ & & & & \\
\hline $\begin{array}{l}\text { Community Reuse Organization } \\
\text { Sale for Reuse, with Off-Site Vendor } \\
\text { Processing of Remaining Railcars }\end{array}$ & $\$ 7.0 \mathrm{M}$ & $\begin{array}{c}240 \mathrm{ft}^{3} \mathrm{MW} \\
13,000 \mathrm{ft}^{3} \mathrm{LLW}\end{array}$ & & & & \\
\hline $\begin{array}{l}\text { Community Reuse Organization } \\
\text { Sale for Reuse, with Disposal } \\
\text { of Remaining Railcars }\end{array}$ & $\$ 9.2 \mathrm{M}$ & $\begin{array}{c}4,700 \mathrm{ft}^{3} \mathrm{MW} \\
79,000 \mathrm{ft}^{3} \text { LLW }\end{array}$ & & & & \\
\hline
\end{tabular}

Key: Relative to baseline approach, atternative produced:

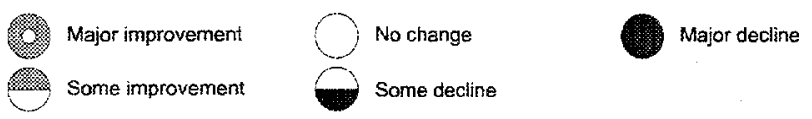

Fig. ES.4. Providing the railcars to the CRO provides cost savings and other benefits, but at some increased programmatic risk. 
Although this study focused specifically on railcars, the method developed and demonstrated in this case study can aid decontamination and decommissioning (D\&D) projects complex-widc. The kcy elements developed and demonstrated herein are as follows:

- Development of a database of information to support $D \& D$ decision-making. To construct the database, we assembled and validated cost information that currently resides in multiple sources of printed material. We built a database to make the assembled data available in real time to multiple users. Documented source material is scanned and made part of the database, so that future users will have immediate access to source material. Use of such a database can greatly streamline future analyses.

- Demonstration of the life cycle analysis process, including problem definition, definition of performance measures, process analysis and alternative identification. alternative evaluation, and visualization of results. Material flow diagrams, cost analysis spreadsheets, and methods used for value-of-information analysis and sensitivity and uncertainty analysis are all presented here. These same methods can be applied for D\&D decision-making complex-wide.

- Demonstration that detailed material flow diagrams are essential to the accuracy of the results. The material flow diagrams developed for this report were the result of numerous iterations with a variety of subject matter experts at the Hanford site as well as with vendors and other parties. The final results of the analysis of these detailed material flow diagrams are significantly different from the initial back-of-the-envelope calculations. The approach taken here-assembling a team of subject matter experts from a wide variety of disciplines and developing detailed material flow diagrams - is highly recommended in order to have confidence in the results.

- New methods for analyzing and presenting the results of life cycle analysis that will help decision-makers make better-informed, more accurate, and more defensible decisions. Traditional cost estimates have been based on single-point estimates. A spreadsheet model was developed that calculated the expected cost of the project. However, this type of presentation, by neglecting the uncertainties involved, does not present a true picture and may lead to poor decisions. This report demonstrates how to improve the analysis of project costs by taking into consideration the uncertainty in the underlying variables. By presenting a more realistic picture of the costs of any proposal, this approach will help D\&D managers move to the next level of decision-making confidence. 


\section{ABBREVIATIONS AND ACRONYMS}

$\begin{array}{ll}\text { AU } & \text { Assets Utilization (ORO) } \\ \text { CRO } & \text { Community Reuse Organization } \\ \text { D\&D } & \text { decontamination and decommissioning } \\ \text { DOE } & \text { U.S. Department of Energy } \\ \text { FMRD } & \text { Facilities and Materials Reuse Division (ORO) } \\ \text { LCA } & \text { life cycle analysis } \\ \text { LLW } & \text { low-level waste } \\ \text { MW } & \text { mixed waste } \\ \text { NMR } & \text { National Center of Excellence for Metals Recycle (DOE) } \\ \text { NRC } & \text { Nuclear Regulatory Commission } \\ \text { ORNL } & \text { Oak Ridge National Laboratory } \\ \text { ORO } & \text { Oak Ridge Operations (DOE) } \\ \text { RL } & \text { Richland (Washington) Operations Office (DOE) } \\ \text { WAC } & \text { waste acceptance criteria }\end{array}$




\section{INTRODUCTION}

Like many other U.S. Department of Energy (DOE) sites, the Hanford Site in Richland, Washington, has a legacy of surplus contaminated materials and equipment. And as is the case elsewhere, DOE program managers must make decisions about what to do with these capital assets. Simply ignoring them is not an option because many of them are contaminated with radiological and chemical hazards. Thus, DOE must consider the option of disposing of these assets as part of its environmental remediation responsibilities. However, many of these materials and pieces of equipment may have value to parties other than DOE-they can be used, for example, as scrap metal (either as-is or after decontamination) or even, in the case of equipment, refurbished and reused by other government programs or by private-sector buyers. Thus, for many capital assets, program managers must consider and decide between the basic alternatives of disposal, recycling, and reuse.

To help address this issue across the DOE sites, in 1997 DOE established the National Center of Excellence for Metals Recycle (NMR), a DOE complex-wide source of information for recycle and reuse of scrap and surplus materials. As current inventories of scrap and surplus materials continue to rise, environmentally safe and cost-efficient solutions are needed. The NMR program is designed to assist project managers in assessing recycling opportunities and provides expertise and tools to facilitate the entire recycling process.

As part of this effort, NMR has developed a set of tools to help project managers recycle materials. A central component of the "toolbox" is life cycle analysis (LCA) to support decision making on whether and how best to recycle surplus materials. An LCA includes all of the impacts (both positive and negative) that result from a course of action over the entire period of time affected by the action. Oak Ridge National Laboratory (ORNL), led by its Center for Life Cycle Analysis, has developed an LCA system for NMR. This system is a systematic and comprehensive process and set of tools for identifying, assessing, and comparing material disposition alternatives and for selecting and documenting a preferred alternative.

The LCA system consists of a user-friendly, cost-effective, and analytically sound decision-aiding process and a complementary suite of tools to handle data administration, assessment, and multiplecriteria decision analysis. The system also includes visualizations that aid communication and help make decision making transparent. Originally developed for use at the Oak Ridge East Tennessee Technology Park, the LCA approach has been refined through application at Ohio Operations Office sites and is now being deployed at sites throughout the DOE complex to help make better decisions, resulting in lower cost to the taxpayer and improved environmental quality.

This report presents the use of the LCA system developed at ORNL to assist the DOE Hanford Equipment Disposition Program in making decisions regarding the disposition of eight types of surplus railcars. The LCA identifies railcars with high potential for cost-effective recycling and evaluates alternative possible mechanisms for accomplishing that recycling. We will examine, first, how the LCA process works in its application to equipment disposition and decontamination and decommissioning (D\&D) problems in general, then look briefly at the LCA system's "toolbox," and finally, see how the process was applied in analyzing disposition of railcars at Hanford. 
" 


\section{The Life Cycle Analysis Process}

ORNL's Center for Life Cycle Analysis has developed an LCA system that provides a systematic, comprehensive, cost-effective decision-aiding process and a complementary suite of tools that has been proven to help DOE make better decisions. The LCA system is a powerful decision support methodology that is especially valuable in D\&D decision making because it provides a systematic, comprehensive approach that can aid the full range of D\&D decision making contexts.

We define LCA as the process of identifying and assessing all categories of benefits and costs that result from a course of action over the entire period of time affected by the action and doing so in a manner that promotes sound decision making. Benefits and costs for options are considered on three levels. The first is a financial level-i.e. the direct financial costs and benefits of the options being considered to address a particular issue or goal. Iowever, if the process stopped at this level, not all costs and benefits of the options would be considered, and poor decisions could result. At the second level, in addition to the direct financial impacts of the alternatives, the quantifiable external effects are considered. These external effects include environmental, public health and worker safety, indirect economic, and socio-institutional impacts. In some cases these external impacts can be quantified and reduced to dollar values. Methodologies such as contingent valuation and conjoint analysis can, in some cases, be used to place a dollar value on avoiding environmental damages. Indirect economic impacts can be assessed by, for example, input/output models; and health and worker safety issues can be evaluated using a variety of methodologies. In some cases, however, we have no appropriate way to place a dollar value on these external impacts. Nevertheless, those impacts may be very important to the decision maker and the communities that will be impacted by DOE's decision. Thus, a third level of analysis is often required to make an informed decision. This third level will consider all direct financial costs and benefits, all quantifiable external costs and benefits, and nonquantifiable effects and considerations. For example, socio-institutional impacts often are nonquantifiable, but may be crucial to successful DOE decisions.

The ORNL approach to LCA differs from other approaches by taking into consideration all the factors important to decision makers (e.g., life cycle cost, health and safety, the environment, programmatic impacts) over the entire life cycle. Historically, decisions were based primarily on meeting near-term objectives, and there is evidence that in some cases DOE failed to realize potential cost savings, environmental benefits, and health and safety improvements. By considering all costs and benefits, regardless of which organization pays those costs or realizes those benefits, LCA can reveal superior decisions for the Department.

The LCA process considers the total costs and benefits of proposals - financial, health and safety, environmental, and programmatic - regardless of which organization realizes those costs and benefits. Consideration of the various impacts associated with a decision need not in all cases be extensive or excessively burdensome; it should be commensurate with the potential benefits of an indepth analysis and consistent with the resources available for assessing the alternatives. However, the fundamental process of considering each of the alternatives on each of their relevant attributes will ensure that all factors important to the decision have been considered and the likelihood of unintended consequences will be reduced. Only by considering all impacts of decisions over the total life-cycle, can managers be confident that thcy arc determining the wisest choice for DOE. 
DOE program managers do not have the time and the resources to conduct exhaustive data collection and assessment efforts to evaluate all potential alternatives over all potential decision critcria related to the disposition of facilities and capital assets. They need a practical and streamlined yet analytically structured approach to this class of decision problems. Specifically, the decision-aiding approach itself needs to meet these criteria:

- Cost-effectiveness. Data needed for the LCA system must be straightforward to collect, and the collection efforts must not require undue time and money. The process must be systematic and easily implemented.

- Comprehensiveness of decision factors. The LCA system needs to encompass a range of decision factors to allow decision makers to understand the complex context of their decisions.

- Defensible results. The outputs of the system must be rigorous and replicable.

- Standardization. The approach must be standardized so that cross-site and cross-program comparisons are possible.

- Robust. The approach must be applicable to D\&D, pollution prevention, and asset recovery across the DOE complex.

The Center for Life Cycle Analysis has developed an LCA approach that meets these criteria.

The ORNL LCA approach has its foundations in the field of decision analysis. Simply stated, the goals of decision analysis are to help people understand the problems they face, construct decision alternatives (options) to solve the problems, specify criteria (attributes) over which to evaluate decision alternatives, and make trade-offs among decision alternatives and criteria to arrive at reasonable and defensible decisions. The LCA approach considers each of the alternatives on each of the relevant attributes in order to ensure that all effects are considered when making decisions and to reduce the likelihood of unintended and unforeseen consequences.

The process itself involves five steps:

1. defining the problem,

2. specifying criteria on which to evaluate possible solutions,

3. identifying the alternative possible solutions,

4. evaluating the alternatives on the basis of the criteria that have been established, and

5. making the decision.

These steps are elaborated in the sidebar. In each of these steps, stakeholders may be directly involved or their concerns may be considered. Although presented here as a linear process, the process is in fact iterative. For example, we typically perform a quick initial investigation, and this will suggest new, improved decision alternatives for evaluation.

Many factors influence D\&D, pollution prevention, and asset recovery decisions. Five decision criteria which have been seen as important in many similar situations are

1. life cycle cost,

2. environmental impacts,

3. public and worker health and safety impacts,

4. pollution or waste prevented, and

5. programmatic and/or institutional impacts. 
THE STEPS IN LIFE CYCLE ANALYSIS

1. Defining the Problem - LCA begins by assembling a project team. Its members then work together to clearly state the problem that needs solution. This step focuses on (1) ensuring that we are addressing the real problem, not merely a symptom; (2) specifying the scope of the study and the inventory to be addressed; and (3) getting all those involved in the decision making process familiar with the issue and involved in the process from the beginning. In the case of highly participative decision making, many more people will be involved in helping confront the issue than were involved in identifying the issue. Thus, many people may need to be introduced to the issue under consideration.

2. Specifying Criteria for Evaluating Possible Solutions - The second step involves specifying criteria by which to evaluate the decision alternatives. The criteria should be developed by the project team appropriate to the problem being considered. But to standardize D\&D decision making and to make the process systematic and easily implemented, it helps to have a core set of criteria that are always considered in D\&D decision-making. ORNL has developed a core set of six criteria: life cycle cost, pollution or waste generated, environmental impacts, health and safety impacts, programmatic impacts, and institutional impacts.

3. Constructing the Alternative Possible Solutions - For better-known issues, the alternatives may already be well known and defined. In other cases, alternatives considered in other but similar situations may be borrowed for consideration. At times, the D\&D problem may be unique and so complex that a structured brainstorming process may be required to generate alternatives. The set of alternatives should include alternatives that are reversible, are multipronged (i.e., entail a portfolio of actions to improve learning potential and to guard against unexpected events), and are a synthesis of actions over time. In situations of great uncertainty, alternatives employing an incremental strategy should be included: small steps, monitoring, reassessment, additional small steps, etc.

4. Evaluating the Alternatives - In the fourth step analytical methods are used to evaluate how well each alternative satisfies each evaluation criterion. To begin, a detailed material flow diagram is drawn for each alternative. The flow diagram includes every step in the life cycle, regardless of the organization involved or the time at which it occurs. Only after every step in the life cycle has been identified can we be confident of making a fair comparison of the financial, environmental, health and safety, and other impacts of the alternatives.

Uncertainty analysis is performed to take into consideration the uncertainty in the underlying variables and provide a truer picture for decision makers. Frequency charts describe the range of possible outcomes and the likelihood of occurrence. Sensitivity analysis and value-of-information analysis are used to determine where additional investigation is warranted-i.e., does the potential benefit of additional investigation justify the cost of obtaining the information? An iterative process is used in which decision alternatives are revised as preliminary analysis suggests new, better alternatives.

5. Making the Decision - Often, after participants have gone through the preceding steps, with iterations to develop improved alternatives, the decision becomes clear. Arriving at reasonable and defensible decisions, however, may be challenging in situations where none of the decision alternatives is dominant. If no alternative is best on every criterion, it may be possible to mount a logical argument in support of one of the alternatives. Or it may be possible to eliminate alternatives that do not meet minimum criteria thresholds. After one or more alternatives have been eliminated, it may be clear which of the remaining alternatives is preferred.

In situations where it is difficult to identify a preferred alternative, the alternatives can be ranked using multi-attribute decision analysis, in which the results of the LCA are combined with weighting factors to produce an aggregate score for each alternative. The weighting factors reflect judgments regarding the relative value of making improvements according to one criterion (e.g., life cycle cost) relative to making improvements according to another criterion (e.g., programmatic impacts). Ideally, the weighting factors are defined through a consensual process that includes stakeholders.

Analyses are also performed as part of this step to identify conditions under which the rank order of the alternatives would change. Finally, LCA uses a variety of visualization techniques to synthesize all the information and communicate the results. 
Ideally, all possible alternatives are evaluated against these decision criteria. The results are then summarized in a decision matrix similar to the one shown in Fig. 1. This is an LCA decision-aiding framework that provides a proven structure to organize data pertinent to the decision. The rows of the matrix list the decision alternatives and the columns, the decision criteria. The cells of the matrix hold the assessments of how well a particular alternative meets a particular criterion. On the basis of the evaluation, the "optimum" alternative is then identified.

\section{Hypothetical Analysis of Asset Utilization Proposal}

\begin{tabular}{|c|c|c|c|c|c|}
\hline Nenraycs & $\begin{array}{l}\text { Whe cycts } \\
\text { Cost }\end{array}$ & Emioninghal & 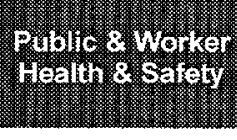 & Warto rroventeo & Programinatio \\
\hline Baseline Process & $\$ 1 \mathrm{M}$ & & & & \\
\hline Proposed Process & $\$ 0.5 \mathrm{M}$ & & & (3) & \\
\hline
\end{tabular}

Key: Relative to baseline approach, alternative produced:

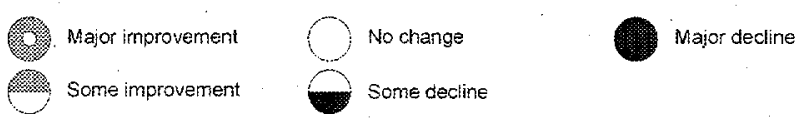

Fig. 1. An example of an LCA decision matrix.

The real world complicates the implementation of this simple model in many ways. Often, time and money constraints limit the amount of data that can be collected for input into a decision analysis, the number of alternatives that can be considered, and the sophistication of the models used to evaluate alternatives over decision criteria. Policy issues surrounding decision contexts often influence how (and maybe even whether) the results of decision analyses are ultimately used.

The approach presented here addresses these major problems. First, the approach is as streamlined as possible. Only the minimum amount of information needed to make reasonable and defensible decisions is collected. Standard spreadsheet tools are used to support quantitative analyses. Other decision inputs are based on the judgments of experts, decision makers, and relevant stakeholders. Second, the approach makes as transparent as possible the values people place on various evaluation criteria. This fosters involvement of multiple stakeholders and communication of their values to other stakeholders. Given that public participation is becoming more important in all aspects of public environmental decision making, this is an especially important aspect of this approach. 


\section{THE LCA TOOLBOX}

The LCA system as developed by ORNL includes numerous tools that provide a wide variety of methods for evaluating costs and benefits of alternative problem solutions. For example, ORNL has developed tools to help model processes, estimate human health and ecological risks, estimate costs, and represent uncertainties.

The primary tools used in the evaluation of material disposition at the Hanford site were

- data acquisition sheets developed to obtain data about buildings, capital equipment, and recoverable assets such as metals;

- a database containing the information acquired in the data acquisition sheets, as well as information from ORNL cost and health and safety databases;

- flow diagrams for each of the possible solutions; and

- customized spreadsheets to calculate all the cost elements defined in the flow diagrams and software allowing uncertainty and sensitivity analyses.

\section{Data Acquisition Sheets}

The purpose of the data acquisition sheets is to ensure that all information that might be relevant to the ultimate decision about an unused asset (e.g., a building or a piece of capital equipment) is collected, or at least, that there is an attempt to collect it. Three types of sheets have been developed: a building assessment checklist, a capital equipment asset checklist, and a building status sheet. These sheets are intended to be generic and usable by all DOE sites for all types of buildings and assets. The development of questions in the sheets has been guided by strong a priori beliefs as to the general nature of the decision alternatives and the evaluation criteria. However, there are numerous variations of each basic decision alternative that the collected data should support.

The information collected for these sheets comes from a variety of site documents (e.g., project baseline summaries, end-use plans, waste management plans, safety analysis reports), as well as from site walk-throughs or walk-arounds, and interviews with site personnel.

\section{The Database}

A crucial tool in the analysis process is the database. As part of this work, the Center for Life Cycle Analysis at ORNL developed a database of information to support D\&D decision-making. To construct the database, we assembled and validated cost information that currently resides in multiple sources of printed materials. We built a database to make the assembled data available in real time to multiple users. Documented source material is scanned and made part of the database, so that future users have immediate access to source material. The goal is to have a source of validated data that can be used to evaluate projects within DOE and support decisions regarding D\&D, asset recovery, and pollution prevention. Figures 2 and 3 show screenshots of the ORNL LCA database and of source material in the database. 


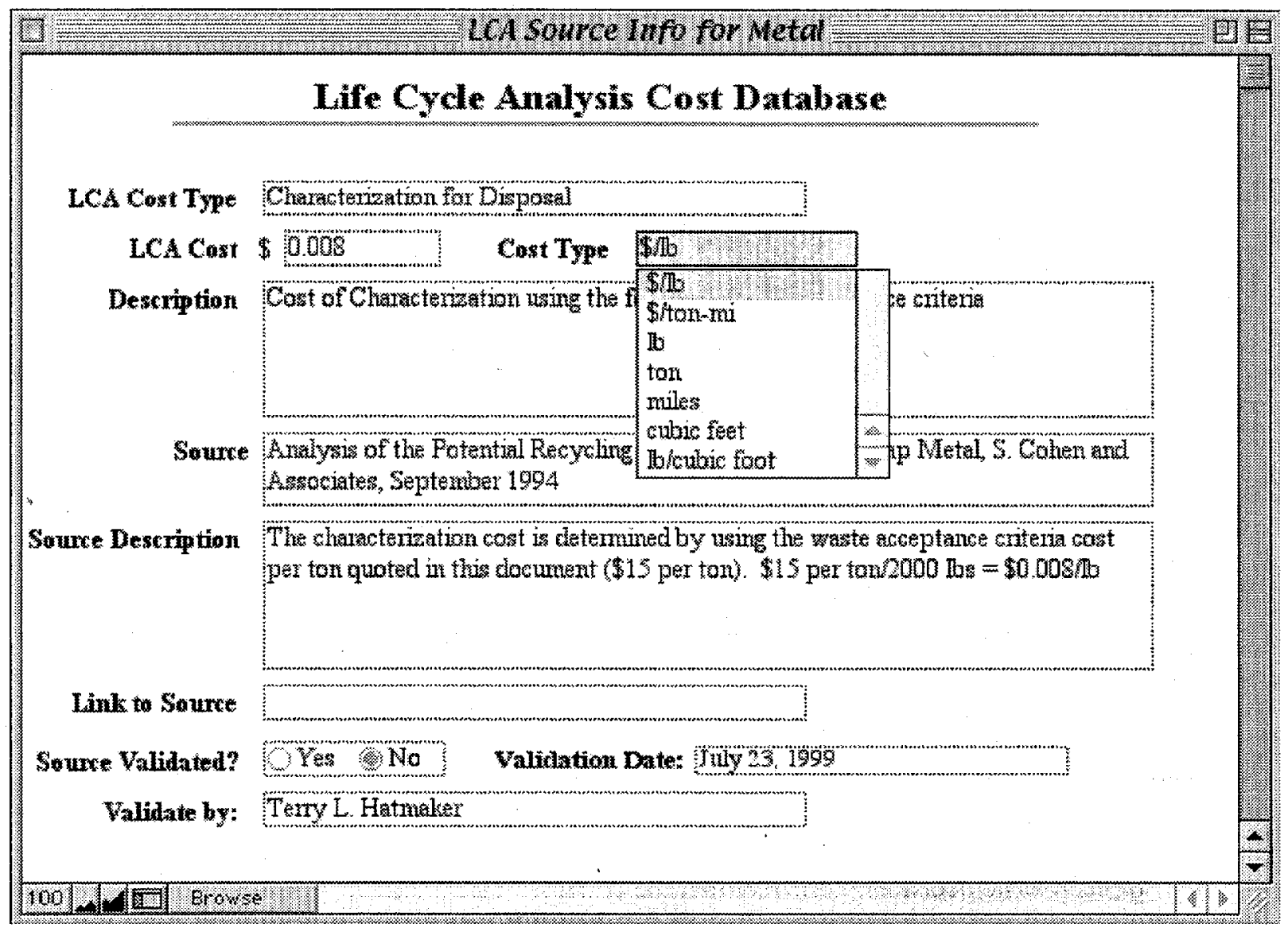

Fig. 2. A screenshot of the ORNL LCA database. 


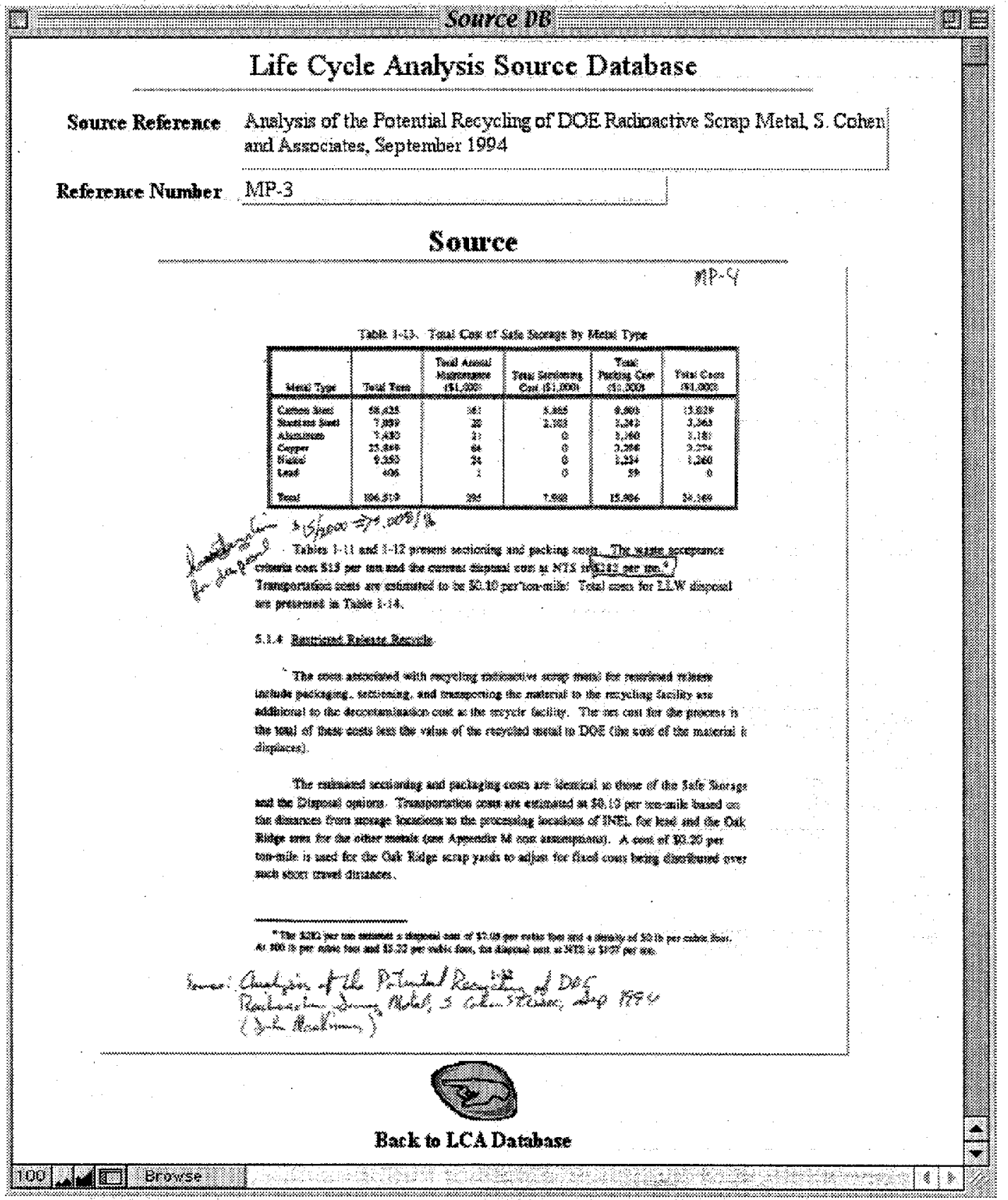

Fig. 3. A screenshot of typical source material incorporated in the LCA database. 


\section{Flow Diagrams}

Flow diagrams are an essential part of the life cycle analysis process. They are developed to track all energy and material flows associated with the life cycle of a product, a project, or a policy proposal. Tracking material flows is a fairly standard aspect of LCA. Our approach is different in that we also track material flows associated with decisions. For example, to assess the costs and benefits of decisions related to the disposition of unused materials at DOE sites, we develop material flow sheets associated with each decision alternative (e.g., to dispose of slightly radioactive metals in a burial site or to recycle the metals into products usable by government and/or industry). Figure 4 illustrates a typical material flow diagram used in this type of analysis.

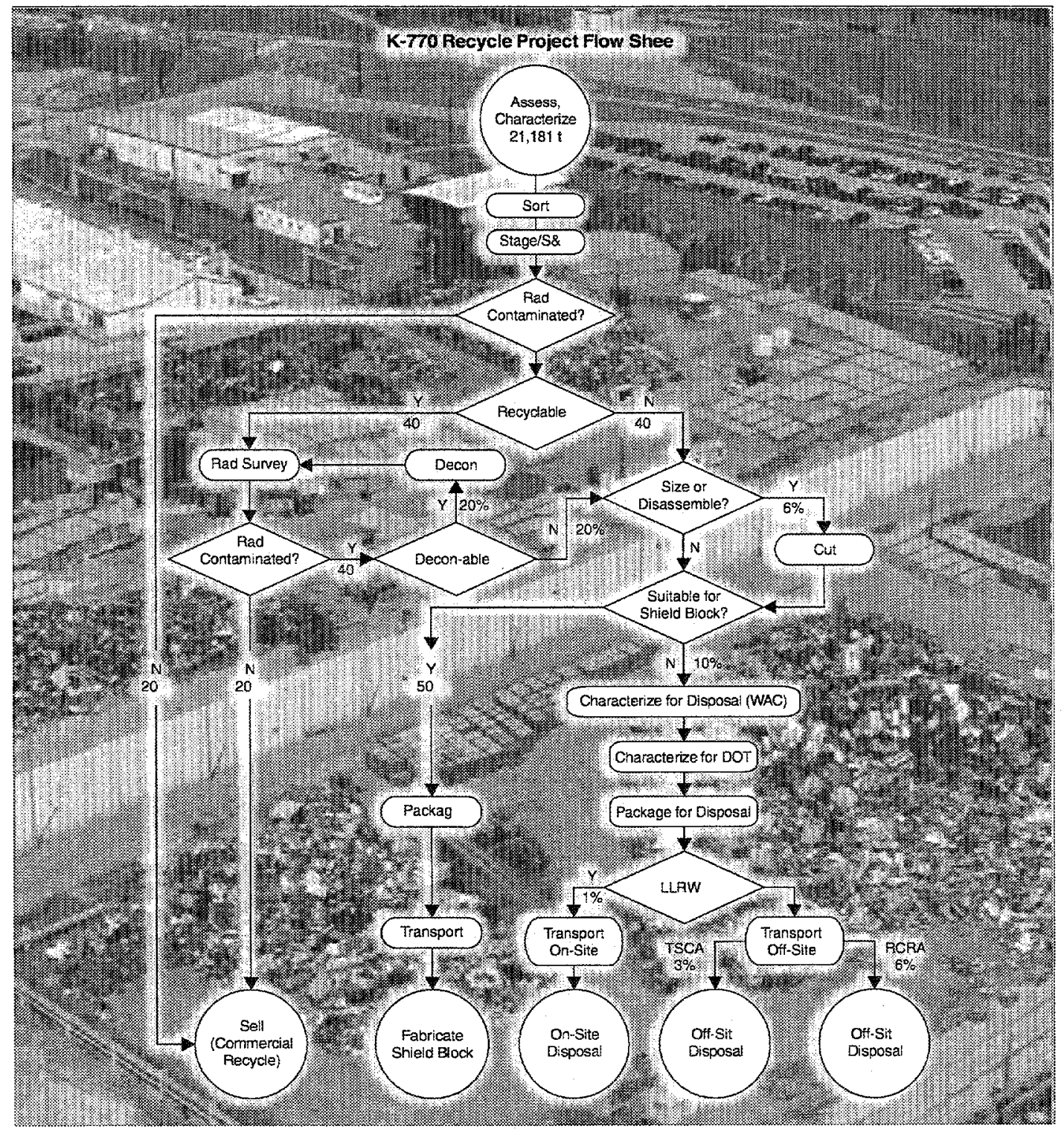

Fig. 4. Typical materials flow diagram. 


\section{Cost Spreadsheets and Uncertainty and Sensitivity Analysis}

This type of presentation neglects the uncertainties involved, however. It therefore does not present a true picture and may lead to poor decisions. This report demonstrates how to improve the analysis of project costs by taking into consideration the uncertainty in the underlying variables. By presenting a more realistic picture of the costs of any proposal, this approach will help D\&D managers move to the next level of decision-making confidence.

In this new approach, we no longer rely on single-point estimates. We begin by designing and building customized spreadsheets using data from the database to calculate all the cost elements defined in the flow diagrams for each of the alternatives. Then, using a software program called Crystal Ball, we replace each of the uncertain variables in our cost model with a range of possible values. Each value in the range has a probability of occurrence. $\mathrm{A}$ simulation is then run, simulating thousands of potential outcomes by running thousands of trials. The result is a frequency chart that represents all of the possible outcomes (see Fig. 5). Using this frequency chart, decision makers can determine not only the range of possible outcomes but also the likelihood of occurrence.

For example, Fig. 5 displays the expected range of costs for disposal of the Hanford railcars at an $80 \%$ confidence level. The total cost of disposal is expected to be between $\$ 11.5$ and $\$ 12.9$ million at an $80 \%$ confidence level. At a $100 \%$ confidence level, the cost is estimated to be between $\$ 10.7$ and $\$ 13.5$ million. In addition, we can determine the likelihood of saving money by recycling the material rather than disposing of it, as shown in Fig. 6.

\section{Uncertainty Analysis}

Companies have used spreadsheets in making business decisions since the 1980s. However, spreadsheet programs are limited in what they do, so businesses have had to look to other solutions to make more accurate and efficient decisions. Spreadsheets have two major limitations:

- The user can change only one spreadsheet cell at a time.

- "What-if" analysis results in single-point estimates that do not indicate the likelihood of achieving a particular outcome.

In order to overcome these limitations, the user must be able to describe a range of possible values for each uncertain cell in the spreadsheet and have a way to measure the effects of these uncertainties.

Uncertainty analysis software is used to help overcome these two limitations. We use a graphically oriented forecasting and risk analysis program to extend the capabilities of our spreadsheets. The program allows us to describe a range of possible values for each uncertain cell in our spreadsheet; everything we know about each input value is expressed all at once. Once we have described our uncertainties, the program uses Monte Carlo simulation to display results in forecast charts that show the range of possible outcomes and the likelihood of achieving each of them. This allows us to provide a statistical picture of the range of possibilities for our assumptions rather than just single-point estimates. 
To determine which uncertain variables have the greatest impact on the results, we perform a sensitivity analysis. For example, in the case of the comparison of decontamination and release of railcars vs disposal at Hanford, sensitivity analysis reveals that the disposal cost is by far the greatest driving factor. Decontamination cost and metal melt cost also drive the results, but much less so than disposal cost. If disposal cost drops and decontamination and metal melt costs increase, one might reconsider a decision favoring recycle.

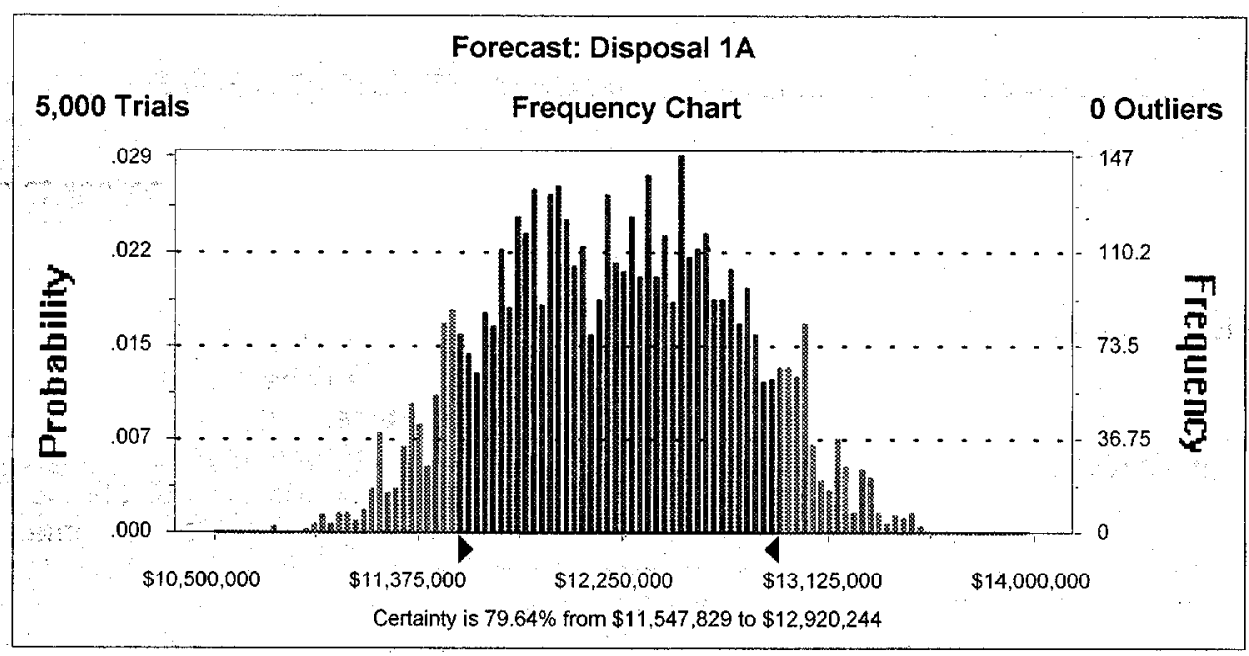

Fig. 5. A frequency chart representing all possible outcomes for a disposal alternative. At an $80 \%$ confidence level, the cost of disposal is expected to be between $\$ 11.5$ million and $\$ 12.9$ million.

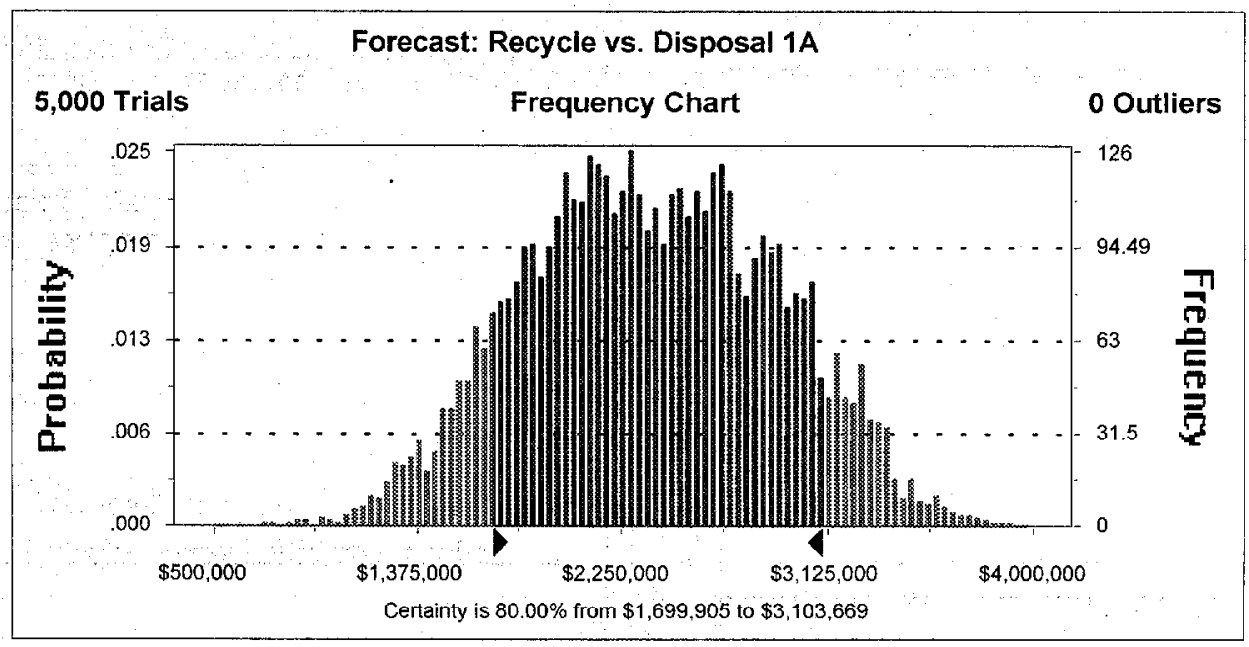

Fig. 6. A frequency chart representing the cost savings from recycling relative to disposal. At an $80 \%$ confidence level, the cost savings are expected to be between $\$ 1.6$ million and $\$ 3.1$ million. 


\section{USING THE LCA SYSTEM AT HANFORD}

As noted in the sidebar on page 5, the LCA process involves five steps:

1. definition of the problem,

2. specifying criteria on which to evaluate possible solutions,

3. identifying the alternative possible solutions,

4. evaluating the alternatives on the basis of the criteria that have been established, and

5. making the decision.

Although presented here as a linear process, the process is in fact iterative. For example, we typically perform a quick initial investigation, and the initial investigation will suggest new, improved decision alternatives for evaluation.

\section{ORNL LCA Capabilities}

- Definition of problem

- Definition of performance measures

- Identification of alternatives

- Evaluation of alternatives

- Develop flow diagrams

- Build spreadsheet

- Use ORNL cost and health and safety databases

- Perform sensitivity and uncertainty analysis

- Visualization of results

\section{Defining the Problem and Collecting the Data}

The LCA team visited Hanford July 19-22, 1999. Our first step was to assemble the project team, consisting of subject matter experts from the Hanford site, ORO, and ORNL. Working closely with site personnel is essential at every step of the LCA process. The project team consisted of experts in the following fields: project management, metal recycling, health physics, safety, accounting, pollution prevention, field sampling, and equipment disposition. The project team worked together to define the problem and possible alternative solutions, specify objectives, and gather data. DOE provided the problem statement for the task: how to dispose of 25 surplus railcars at the Hanford site.

The railcars evaluated at Hanford fall into eight classes:

1-2. flat $\mathrm{BN}$ and flat $\mathrm{PX}$ - standard railroad flatcars;

3. well $10 \mathrm{~B}$ - a drop-center railcar that has a steel box containing three lead fuel casks and that was used to haul fuel;

4. cask $10 \mathrm{~B}$ - a flatcar that has a steel box containing one large lead fuel cask and that was used to haul fuel;

5. tank $10 \mathrm{H}-$ - a carbon steel tank car, used to haul radioactive liquid;

6. tank 10A - a double-walled stainless steel tank car, used to haul radioactive liquid;

7. car trucks - sets of wheels, with each car having two sets; and

8. locomotives-two locomotives (Fig. 7).

Photographs of the railcars appear in Appendix A. 
Broadly speaking, the disposition alternatives for the 25 surplus cars were seen as disposal, recycling (either unrestricted release of metal as scrap or melt for shield block), and sale of the railcars for reuse. These alternatives may be defined as follows:

- disposal - bury materials in appropriate mixed and low-level waste disposal facilities;

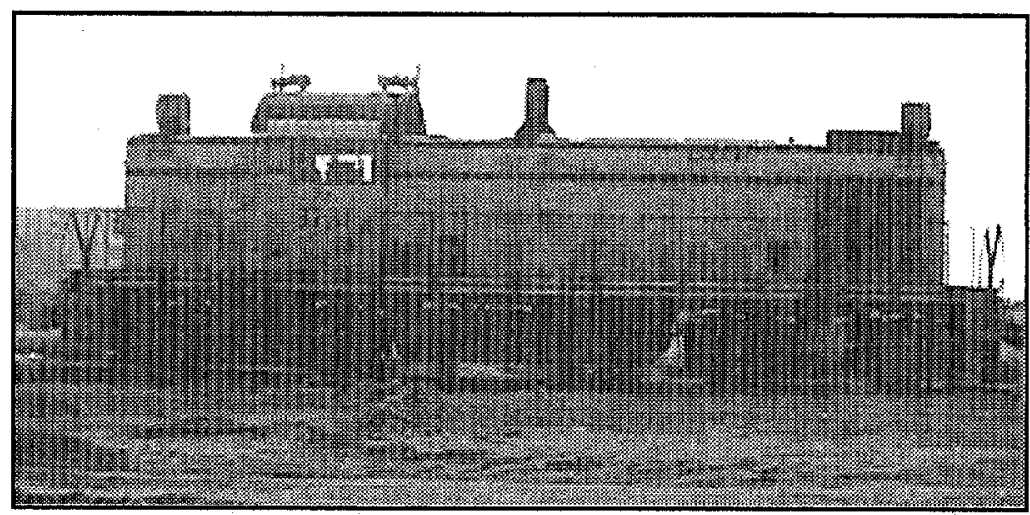

Fig. 7. One of the Hanford locomotives scheduled for disposition.

- recycling - metal is decontaminated (as needed) and sold for scrap or melted for shield block;

- reuse - railcars are sold for reuse as railcars.

Then, using a capital equipment asset checklist, we collected all relevant information about the railcars to support a disposal, recycling, or reuse decision. The following information was collected:

- general information (e.g., location of railcars, number being considered);

- physical descriptions of the cars (e.g., type of car, type of materials used in car, age, weight, volume, condition);

- cost (e.g., initial purchase cost, reuse value, scrap value); and

- contamination and disposition information (e.g., types of contaminants and levels, decontamination methods and costs).

Two of the most important sets of data in regard to these cars were the material composition of the cars (i.e., quantities of steel and lead) and the amount and type of contamination. In order to obtain the data, we examined existing reports, interviewed knowledgeable site personnel, and conducted a "walk-around" assessment of the railcars with site personnel. The data collected was then entered into a database system.

\section{Specifying the Objectives}

Working with the project team, we determined the key objectives to be minimizing life cycle cost, protecting public and worker health and safety, protecting the environment, minimizing pollution or waste generated, minimizing programmatic risk, and maximizing institutional benefits. Programmatic risk captures the risk of failure (e.g., associated with a first-of-a kind activity). Institutional benefits include such things as supporting Hanford revitalization goals. Each alternative was evaluated on the basis of its impact on each of the key objectives. 


\section{Identifying Alternative Solutions}

On the basis of a preliminary analysis of the data collected and through consideration of the specified objectives, we identified five possible alternative solutions for disposition of the Hanford railcars. Two alternatives were established for the disposal option, both involving burial of the cars. Option 2 involves decontamination and recycling of the railcar materials by a commercial vendor. The third and fourth options involve providing the cars to the CRO for decontamination and sale of the cars. In option 3, cars that could not be cost-effectively decontaminated for sale would be sent to a commercial vendor for processing, as described in option 2 . Option 4 is similar to the third option, but in this option, railcars that could not be cost-effectively decontaminated for reuse would be disposed of on-site as described in option 1A. For the purpose of this analysis, it was assumed that the well and cask cars could not be cost-effectively decontaminated for reuse.

In more detail, these alternatives were as follows:

- Option 1: Disposal

- Option $1 A$ (Baseline Approach) - In this alternative the primary components of the railcars, steel and lead, would be separated, processed, packaged, and buried on-site at the LLW and MW disposal facilities, respectively.

- Option $1 B$ - In this alternative the cask and well cars would be disposed of intact at the onsite MW disposal facility. All other cars would be disposed of in the LLW disposal facility.

- Option 2: Off-site decontamination and release of steel and lead - In this alternative the cars would be transported to a Nuclear Regulatory Commission (NRC)-licensed facility, cut up, and decontaminated as appropriate. A large percentage of the steel and all of the lead would then be sold as scrap metal, with a smaller percentage of the steel melted for shield block.

- Option 3: Community Reuse Organization (CRO) decontamination and sale of railcars where cost-effective, with processing of the remaining railcars as described in option 2 - In this alternative the cars would be provided to a CRO. The CRO (or its qualified agent) would decontaminate the cars and sell them for reuse where feasible. Cars that could not be costeffectively decontaminated for reuse would be sent to an NRC-licensed facility for processing as described in option 2. For this option, all well and cask cars were considered too contaminated to be decontaminated for reuse.

- Option 4: CRO decontamination and sale of railcars where cost-effective, with disposal of the remaining railcars as described in option $1 A$ - In this alternative the cars would be provided to a CRO. The $\mathrm{CRO}$ (or its qualified agent) would decontaminate the cars and sell them for reuse where feasible. Cars that could not be cost-effectively decontaminated for reuse would be buried on-site as described in disposal option 1A. Again for this option, all well and cask cars were considered too contaminated to be decontaminated for reuse.

\section{Assessing the Consequences of the Alternatives}

An important task in assessing the alternatives involved developing material flow diagrams for each decision alternative. These were developed in an iterative fashion working with the project team as well as vendor experts. Figures 8-11 show the flow diagrams developed for the disposition 
alternatives. The flow diagrams make explicit all DOE activities involved with disposition of the materials.

In order to assess the consequences of each of the alternatives, we developed a spreadsheet model and populated it with the data from our database. The database includes not only information gathered at the Hanford site via the capital equipment assessment checklists, but also cost information gathered from multiple sources and a health and safety database.

The relevant data were determined from the specified objectives for the project. Therefore, the data to be considered were

- life cycle cost - the total of all monetary costs and benefits associated with an alternative (including all costs to the government regardless of which organization bears those costs);

- environmental impacts - the effects on air and water quality, land use, solid waste, plant and animal species, etc.;

- public and worker health and safety impacts - an estimation of expected fatalities in the exposed population from both radiological and nonradiological causes (c.g., chcmical exposure, transportation accidents, industrial accidents);

- pollution or waste prevented - an estimation of the volume of material disposed of, by type of material;

- programmatic risk - an evaluation of technical risk, ability to meet milestones, time needed to implement the alternative, liability issues, cost uncertainty, and regulatory impacts; and

- institutional impacts - an evaluation of consistency with DOE policy and Hanford revitalization goals.

The spreadsheets were revised via an iterative process, working closely with site and vendor representatives, until they contained all available data relevant to making decisions on the alternatives. The spreadsheets developed for the various alternatives are shown in Appendix B.

The objectives were then examined as follows:

- Life cycle cost. The spreadsheet model generated cost estimates for each alternative.

- Environmental impacts. Experts on the project team made qualitative judgments regarding impacts (e.g., very high to very low) based upon relevant evidence collected on the sheets, applicable databases and software, and literature review.

- Public and worker health and safety impacts. Experts on the project team made qualitative judgments as to impacts (e.g., very high to very low) based upon relevant evidence collected on the sheets, applicable software such as RESRAD, and literature review.

- Pollution prevention. The spreadsheet model estimates volumes and types of materials disposed of under each alternative;

- Programmatic risk. The project team made subjective qualitative judgments (e.g., very high to very low) about programmatic impacts.

- Institutional impacts. The project team made subjective qualitative judgments (e.g., very high to very low) about institutional impacts. 


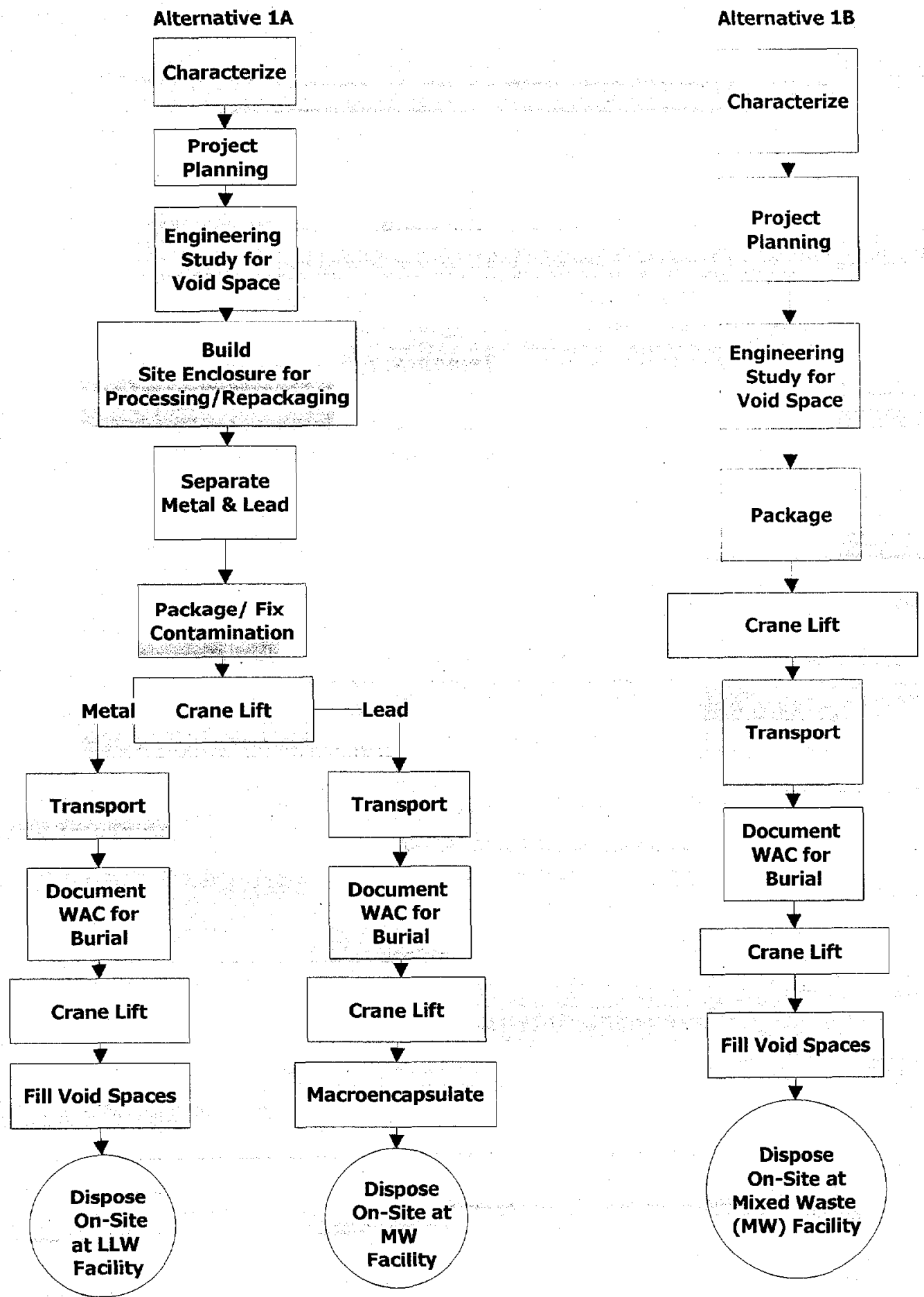

Fig. 8. Material flow diagrams for options 1A and 1B: disposal. 


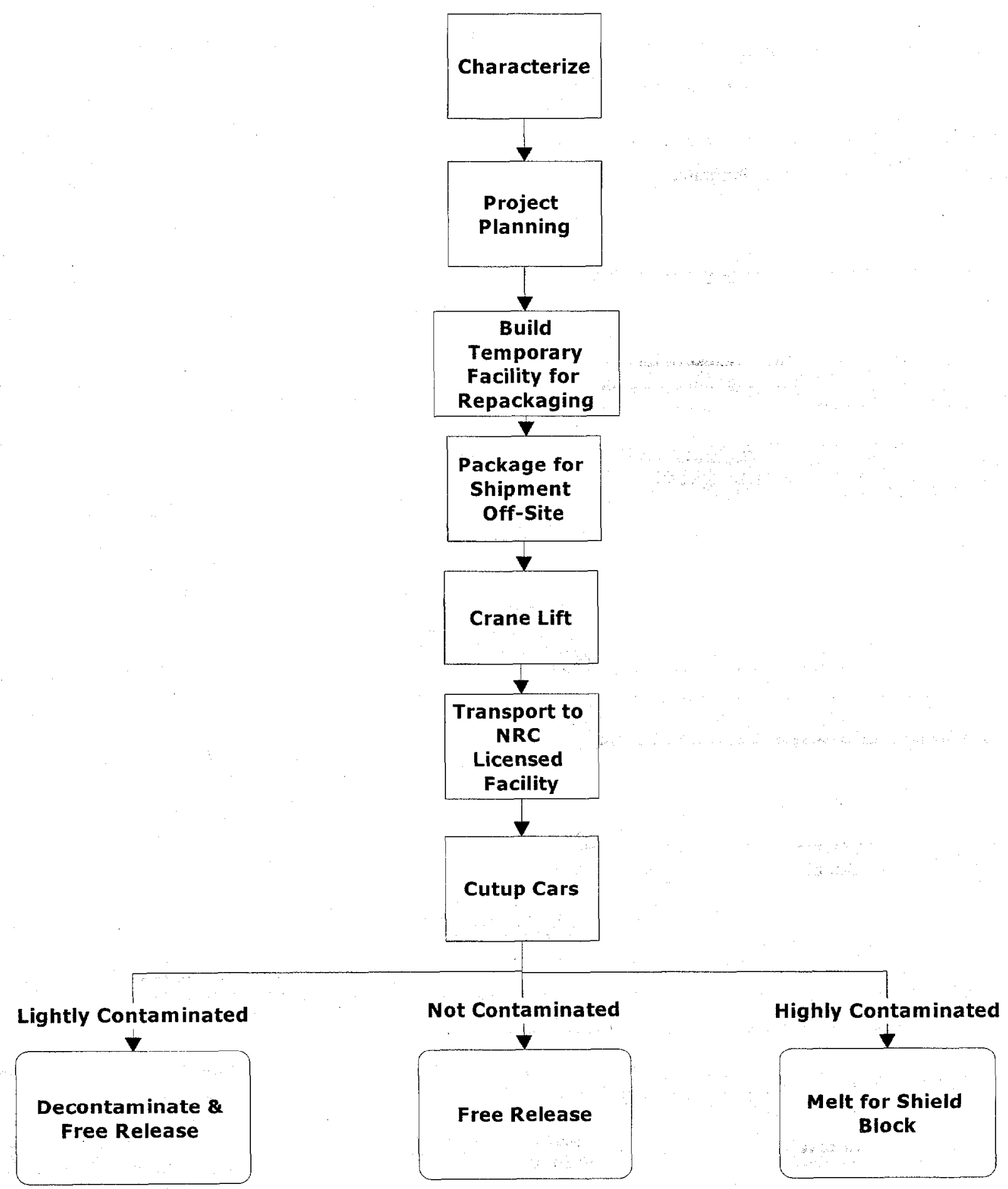

Fig. 9. Material flow diagram for option 2: off-site decontamination and release of steel and lead. 


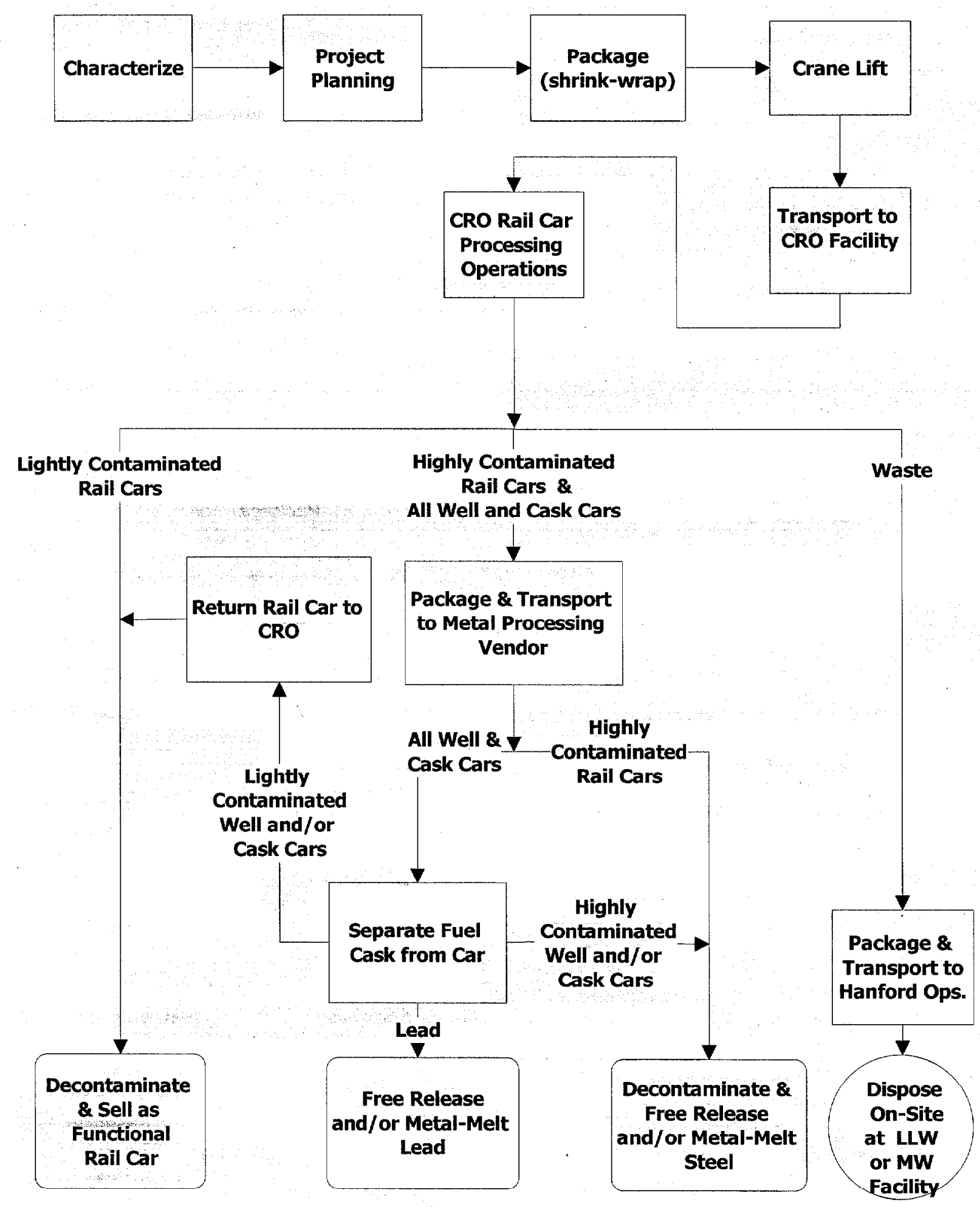

Fig. 10. Material flow diagram for option 3: CRO decontamination and sale of railcars, with off-site processing of remaining railcars for sale as scrap or melt for shield blocks. 


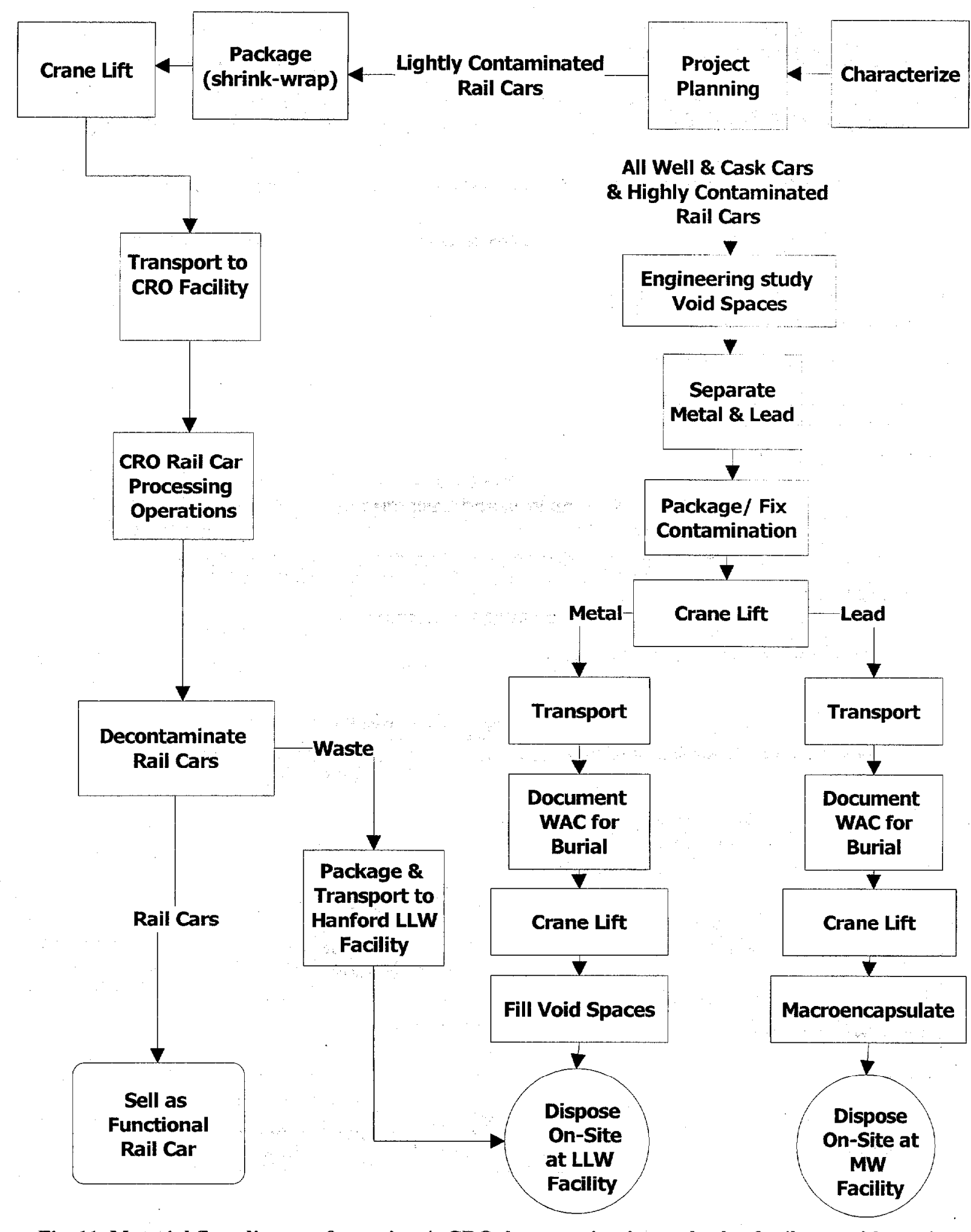

Fig. 11. Material flow diagram for option 4: CRO decontamination and sale of railcars, with on-site disposal of remaining railcars. 
The key assumptions for the analysis were as follows:

1. Project planning cost was estimated at $30 \%$ of the on-site operations cost. Off-site operations carry no project planning costs. This assumption is especially significant for the alternative involving off-site vendor processing (option 2) and the combination CRO and off-site vendor processing alternative (option 3 ).

2. Project management was estimated as $10 \%$ of all costs except project planning.

3. Under disposal option 1A, Hanford Waste Management Operations would first separate the lead casks from the cask and well cars. The lead casks would then be macroencapsulated and disposed of in the MW disposal facility. The void space in the cars would then be filled with an approved fill material and the cars disposed of in the LLW facility. The tanks on the tank cars would also be filled with an approved fill material before disposal in the LLW facility. There would not be any cutting up of the cars, casks, or tanks to consolidate waste volume. Every item would be separated as appropriate, void spaces filled, and the cars buried whole. It should be noted that members of the project team questioned whether the macroencapsulation processing facility could handle lead shapes of this magnitude without first cutting them into smaller pieces prior to macroencapsulation.

4. Under disposal option 1B, Hanford Waste Management Operations would fill the void spaces for the cask, well, and tank cars. Then the entire car would be buricd wholc and intact. All cars except the well and cask cars would be buried in the LLW facility. The well and cask cars would be buried in the MW disposal facility.

5. Most of the data for option 2 (processing of the cars by an off-site licensed vendor) were based on the processing of an actual cask car by a commercial vendor. Actual experience for the 25 railcars evaluated here is likely to vary. For example, the percentage of material going to decontamination and release vs metal melt (estimated as a 60:40 ratio for the well and cask cars based on the vendor experience) would change according to contamination level and the configuration of car construction. Because we expect actual experience to vary for the railcars, the LCA used ranges, rather than point estimates, for each of the variables. Although the flow diagram does not show any material going to disposal in option 2, in actuality some waste would be produced. This waste would be handled and disposed of by the vendor (not returned to DOE); the cost of this waste is included in the cost of the material processing.

6. Under option 3, the CRO processes rail cars and recovers their asset value where feasible; the remaining railcars are processed by an off-site vendor as defined in option 2 . DOE directed us to evaluate this option on the assumption that all cars processed by the CRO for recovery of assets would be at no cost to the government except for disposal of a maximum of $10 \%$ waste (based on the original railcar volume) produced during the processing. This waste would be processed, characterized, and packaged by the CRO to meet the waste acceptance criteria (WAC) of the Hanford disposal facility. For purposes of this analysis, all well and cask cars were assumed to be processed by an off-site vendor as defined in option 2. Even though DOE specified a maximum of $10 \%$ waste (by volume) returned to the government, we evaluated a range of 5 to $20 \%$ under the uncertainty analysis. The uncertainty analysis also evaluated the consequences if the CRO should be unable to handle any or all of the different types of cars.

7. Under option 4, the CRO processes railcars and recovers their asset value where feasible; the remaining railcars are disposed of as defined in option $1 \mathrm{~A}$. As in option 3, DOE directed us to evaluate this option on the assumption that all cars processed by the CRO for recovery of assets would be at no cost to the government except for disposal of a maximum of $10 \%$ of the waste (based on the original railcar volume) produced during the processing. This waste would be processed, characterized, and packaged by the CRO to meet the WAC of the Hanford disposal facility. Consistent with the assumptions made for the other alternatives, all well and cask cars 
were assumed to be disposed of as defined in option $1 \mathrm{~A}$. In a fashion similar to option 3 , the uncertainty analysis evaluated a range of waste quantities returned by $\mathrm{CRO}$ to the government for disposal.

8. Base case assumptions used for the calculation of waste volumes are as follows:

- For option 2 (off-site vendor processing), the cars are packaged and shipped directly to the vendor from Hanford. Vendor processing was assumed to generate $5 \%$ waste by volume (for both the steel and the lead).

- Under option 3 (CRO with off-site vendor processing), the CRO receives all the cars, evaluates the cars, and attempts to decontaminate them as appropriate, thereby generating some waste. Cars that cannot be decontaminated are sent to the off-site vendor for processing. Because of the additional processing steps involving the $\mathrm{CRO}$, this option was assumed to generate $10 \%$ waste by volume, for the steel. For the lead, we assumed $5 \%$ waste generated. (This figure is not increased for CRO handling because we assumed that the CRO would not attempt to handle the lead under any circumstances.)

- Under option 4, we assumed that all the well and cask cars are directly disposed of on-site under the option 1A scenario. We also assumed that $100 \%$ of the other cars could be decontaminated by the CRO and produce $10 \%$ waste by volume. These assumptions were varied for the uncertainty analysis.

\section{Results of the Analysis}

The results of the cost analysis, summarized in Fig. 12, show that the most cost-effective option is option 3: providing the railcars to the CRO for decontamination and sale of the railcars where feasible. Railcars that are too contaminated for decontamination and sale would be transported to an NRC-licensed facility, cut up, and decontaminated. A large percentage of the steel and all of the lead would then be sold as scrap metal, with a smaller percentage of the steel melted for shield block.

Uncertainty and sensitivity analyses were performed because of the large uncertainties in the underlying variables. Input parameters were varied over ranges that represent the reasonable range of possible values. For example, sensitivity analysis showed that a key uncertainty is the number of cars the CRO would be able to decontaminate for reuse. Therefore, we evaluated the worst case, that the $\mathrm{CRO}$ is unable to decontaminate for reuse any of the cars and must send all of them to a vendor for

\begin{tabular}{|c|c|c|c|c|c|c|c|c|c|}
\hline Alternative: & $\begin{array}{l}\text { Flat } \\
\mathrm{BN}\end{array}$ & $\begin{array}{l}\text { Flat } \\
\text { PX }\end{array}$ & $\begin{array}{l}\text { Well } \\
10 B\end{array}$ & $\begin{array}{c}\text { Cask } \\
10 \mathrm{~B}\end{array}$ & $\begin{array}{l}\text { Tank } \\
10 \mathrm{H}\end{array}$ & $\begin{array}{c}\text { Tank } \\
10 \mathrm{~A}\end{array}$ & $\begin{array}{l}\text { Car } \\
\text { Trucks }\end{array}$ & Locomotive & Total \\
\hline Disposal: Separate LLW and MW & $\$ 311,000$ & $\$ 311,000$ & $\$ 5,638,000$ & $\$ 1,975,000$ & $\$ 474,000$ & $\$ 494,000$ & $\$ 987,000$ & $\$ 667,000$ & $\$ 10,857,000$ \\
\hline $\begin{array}{l}\text { Disposal: Well \& cask cars disposed as MW } \\
\text { remaining cars disposed as LLW }\end{array}$ & $\$ 31 \cdot 1,000$ & $\$ 311,000$ & $\$ 12,893,000$ & $\$ 4,514,000$ & $\$ 474,000$ & $\$ 494,000$ & $\$ 987,000$ & $\$ 667,000$ & $\$ 20,652,000$ \\
\hline Off-Site Vendor Processing & $\$ 413,000$ & $\$ 292,000$ & $\$ 4,012,000$ & $\$ 1,465,000$ & $\$ 278,000$ & $\$ 278,000$ & $\$ 2,267,000$ & $\$ 880,000$ & $\$ 9,885,000$ \\
\hline CRO \& Off-Site Vendor Processing & $\$ 143,000$ & $\$ 143,000$ & $\$ 4,105,000$ & $\$ 1,498,000$ & $\$ 124,000$ & $\$ 126,000$ & $\$ 646,000$ & $\$ 192,000$ & $\$ 6,976,000$ \\
\hline CRO \& On-Site Disposal & $\$ 164,000$ & $\$ 164,000$ & $\$ 5,638,000$ & $\$ 1,975,000$ & $\$ 141,000$ & $\$ 156,000$ & $\$ 702,000$ & $\$ 271,000$ & $\$ 9,209,000$ \\
\hline
\end{tabular}

Note: Totals do not include cost of construction of a facility for characterization of the railcars (est cost $\$ 1.53 \mathrm{M}$, regardless of alternative).

Fig. 12. Costs of the alternatives. The most cost-effective method for disposition of the railcars is Community Reuse Organization (CRO) decontamination and sale of railcars where cost-effective, with processing of the remaining railcars by an off-site vendor for sale as scrap or melt for shield block. 
processing. Sensitivity analyses also showed that the cost of LLW disposal is another key variable. We varied the disposal cost over a range from $\$ 15$ to $\$ 35 / \mathrm{ft}^{3}$. Other parameters were varied in similar manner. Some of the sensitivity analyses performed are summarized in Figs. 13 and 14.

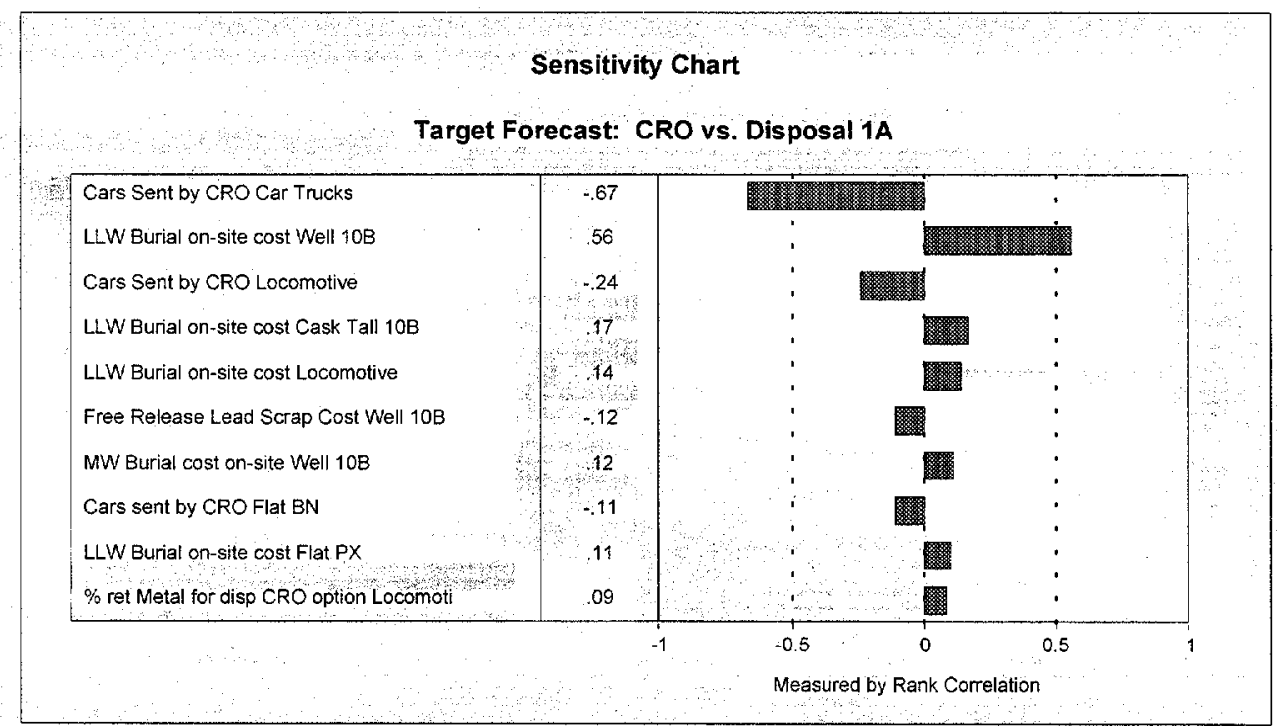

Fig. 13. Sensitivity analysis for comparison of option 3 with option $1 \mathrm{~A}$.

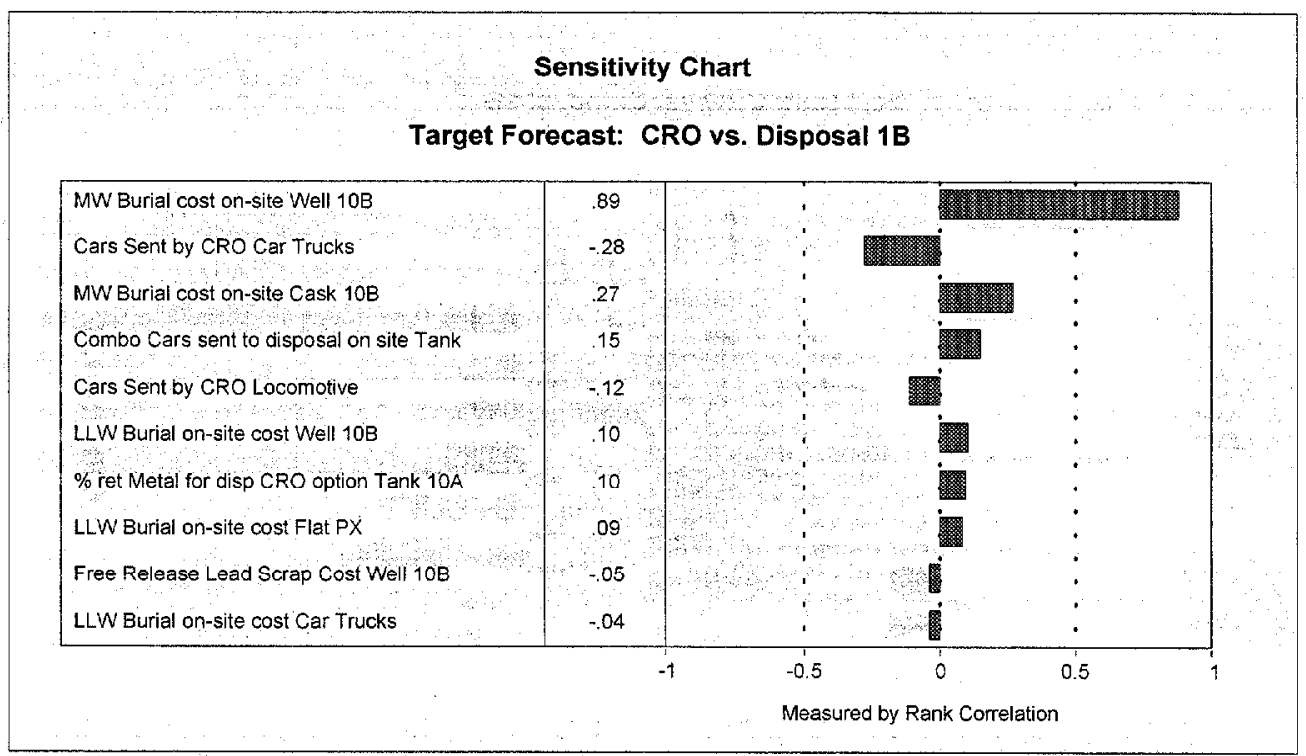

Fig. 14. Sensitivity analysis for comparison of option 3 with option $1 B$. 
Based on the uncertainty analysis, option 3, CRO with off-site vendor, is expected to save between $\$ 2.6$ and $\$ 4.6$ million relative to disposal option $1 \mathrm{~A}(80 \%$ confidence level). These savings are depicted in the frequency diagram presented in Fig. 15. Relative to disposal option 1B, expected cost savings from providing the cars to the CRO range from $\$ 6.6$ to $\$ 11.4$ million. These cost savings are shown in Fig. 16.

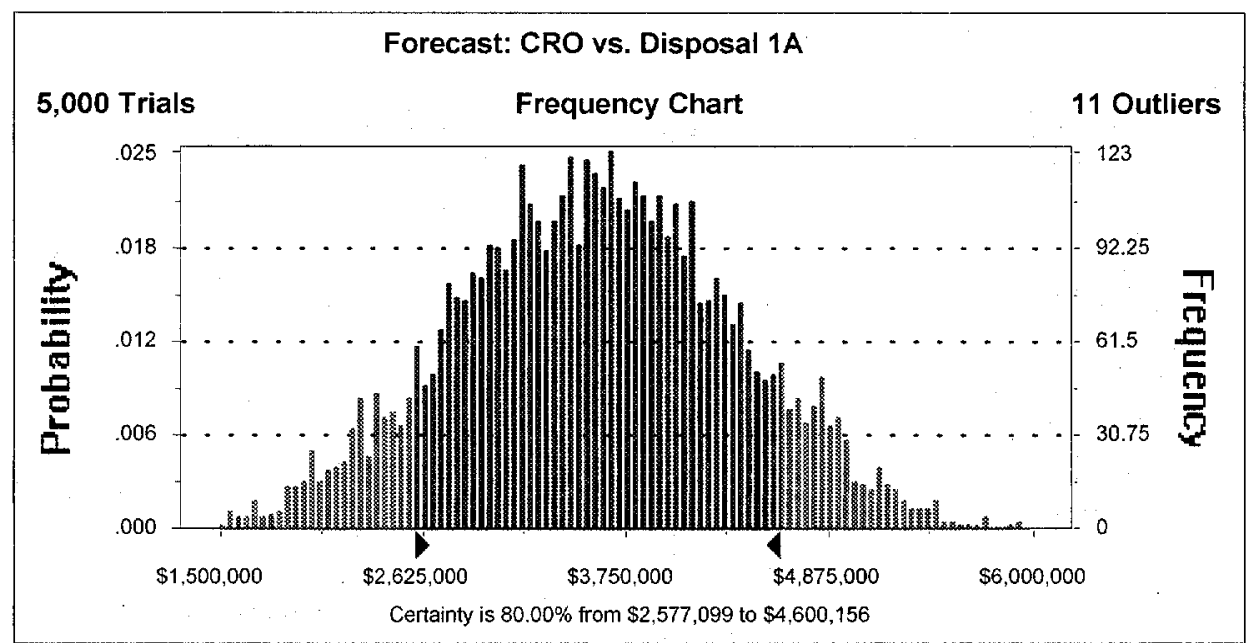

Fig. 15. Expected cost savings from providing the railcars to the CRO (option 3) relative to baseline disposal (option $1 \mathrm{~A}$ ) range from $\$ 2.6$ to $\$ 4.6$ million (at an $80 \%$ confidence level).

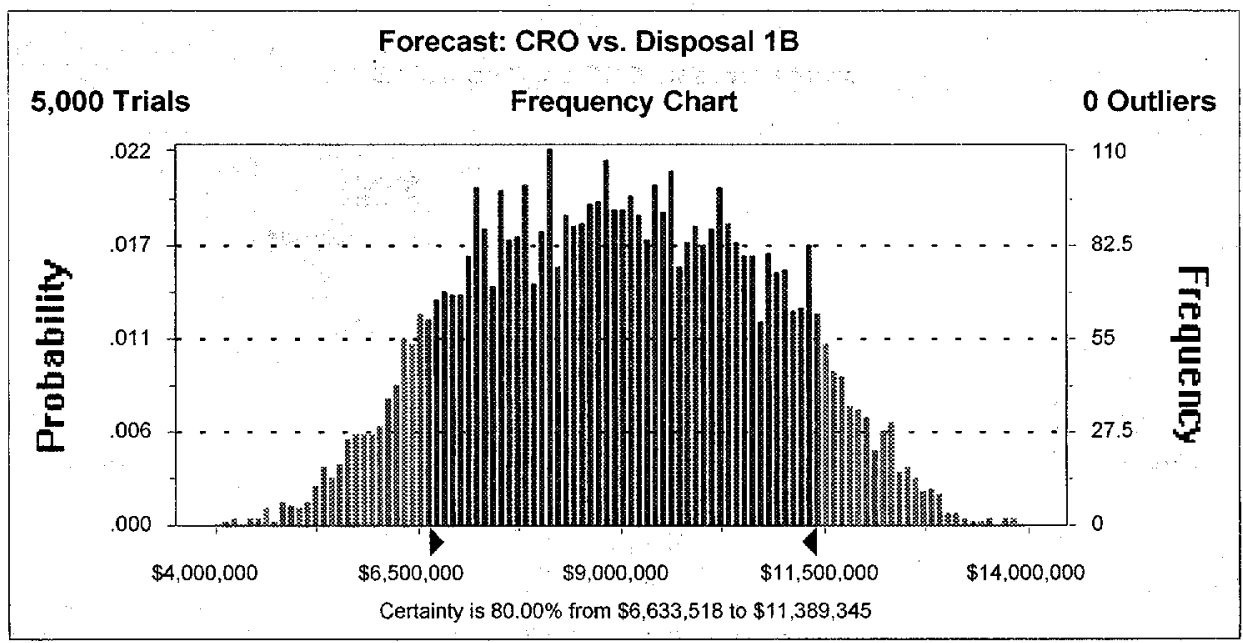

Fig. 16. Expected cost savings from providing the railcars to the CRO (option 3) relative to baseline disposal (option $1 \mathrm{~B}$ ) range from $\$ 6.6$ to $\$ 11.4$ million (at an $80 \%$ confidence level). 
In addition to the cost analysis, we evaluated the quantity of LLW and MW produced under each alternative. Our findings are summarized in Table 1 , and one of the uncertainty analyses for waste volumes appears in Fig. 17. As the graph in this figure shows, relative to the baseline disposal option 1A, option 3 is expected to prevent disposal of from 1770 to 1950 tons of waste (at an $80 \%$ confidence level).

Table 1. Expected waste generated under each alternative

\begin{tabular}{lrrr}
\hline & \multicolumn{3}{c}{$\begin{array}{c}\text { Volume of waste } \\
\text { Alternative }\end{array}$} \\
\cline { 2 - 4 } & LLW & MW & Total \\
\hline Option 1A: Disposal-Separate LLW and MW & 132,000 & 4,730 & 137,000 \\
Option 1B: Disposal-Dispose of well and cask & 58,700 & 78,100 & 137,000 \\
$\quad$ cars as MW; dispose of other cars as LLW & & & \\
Option 2: Off-site vendor processing & 6,600 & 236 & 6,840 \\
Option 3: CRO and off-site vendor processing & 13,200 & 236 & 13,400 \\
Option 4: CRO and off-site disposal & 79,200 & 4,730 & 83,900 \\
\hline
\end{tabular}

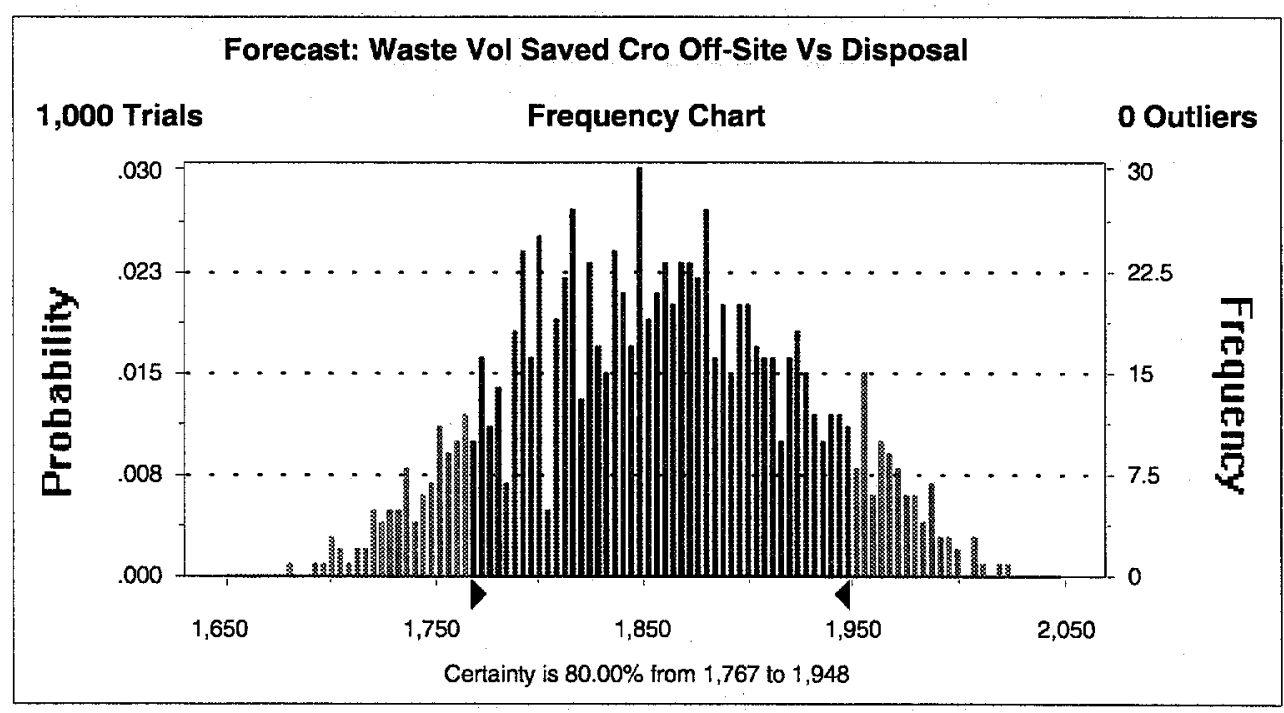

Fig. 17. Expected volumes of waste prevented by providing the railcars to the CRO (option 3) relative to baseline disposal (option 1A) range from 1770 to 1950 tons (at an $80 \%$ confidence level). 
The alternatives were also evaluated for their environmental, health and safety, programmatic, and institutional impacts. This analysis is summarized in Table 2 . The entire analysis is summarized in Fig. 18. Alternatives utilizing the $\mathrm{CRO}$ were considered to have higher programmatic risk than the other alternatives, primarily because of the first-of-a-kind nature of the venture. However, DOE believes this increased programmatic risk is more than offset by the cost savings and institutional benefits resulting from providing the railcars to the CRO. 
Table 2. Summary of health, environmental, programmatic, and institutional impacts of the alternatives

\begin{tabular}{|c|c|c|c|c|}
\hline \multirow[b]{2}{*}{ Alternative } & \multicolumn{4}{|c|}{ Impacts } \\
\hline & $\begin{array}{l}\text { Public and } \\
\text { worker health } \\
\text { and safety }\end{array}$ & Environmental & Programmatic & Institutional \\
\hline $\begin{array}{l}\text { Option } 1 \Lambda \text { : } \\
\text { Disposal-Separate } \\
\text { LLW and MW }\end{array}$ & $\begin{array}{l}\text { Low worker } \\
\text { exposure }\end{array}$ & Neutral & $\begin{array}{l}\text { Low programmatic risk: proven technology, } \\
\text { proven process, greatest control. However, } \\
\text { questions exist regarding planned } \\
\text { macroencapsulation. } \\
\text { Issue: Possible future remediation of disposal } \\
\text { facility }\end{array}$ & Neutral \\
\hline $\begin{array}{l}\text { Option 1B: } \\
\text { Disposal Dispose of } \\
\text { well and cask cars as } \\
\text { MW; dispose of } \\
\text { remainder as LLW }\end{array}$ & $\begin{array}{l}\text { Lowest worker } \\
\text { exposure }\end{array}$ & Neutral & $\begin{array}{l}\text { Lowest programmatic risk: proven technology, } \\
\text { proven process, greatest control } \\
\text { Issue: Possible future remediation of disposal } \\
\text { facility }\end{array}$ & Neutral \\
\hline $\begin{array}{l}\text { Option 2: Off-site } \\
\text { vendor processing }\end{array}$ & $\begin{array}{l}\text { Higher worker } \\
\text { exposure }\end{array}$ & $\begin{array}{l}\text { Better: recycle } \\
\text { material; avoid } \\
\text { disposal }\end{array}$ & $\begin{array}{l}\text { Low programmatic risk: demonstrated } \\
\text { technology, proven process } \\
\text { Positive schedule impact: will accelerate } \\
\text { cleanup at the Hanford site }\end{array}$ & $\begin{array}{l}\text { Institutional benefit: Supports } \\
\text { DOE recycle policy }\end{array}$ \\
\hline $\begin{array}{l}\text { Option 3: CRO \& off- } \\
\text { site vendor processing }\end{array}$ & $\begin{array}{l}\text { Higher worker } \\
\text { exposure }\end{array}$ & $\begin{array}{l}\text { Best: reuse for } \\
\text { intended purpose }\end{array}$ & $\begin{array}{l}\text { High programmatic risk: first-of-a-kind at } \\
\text { Hanford, regulatory uncertainty, loss of } \\
\text { control without loss of liability, unknown } \\
\text { waste returned (type, quantity), highest cost } \\
\text { uncertainty }\end{array}$ & $\begin{array}{l}\text { Greatest institutional bencfits: } \\
\text { jobs created in community, } \\
\text { supports TRIDEC, supports } \\
\text { revitalization }\end{array}$ \\
\hline $\begin{array}{l}\text { Option 4: CRO \& } \\
\text { on-site disposal }\end{array}$ & $\begin{array}{l}\text { Higher worker } \\
\text { exposure }\end{array}$ & $\begin{array}{l}\text { Better: reuse for } \\
\text { intended purpose } \\
\text { with some disposal }\end{array}$ & $\begin{array}{l}\text { High programmatic risk: first-of-a-kind at } \\
\text { Hanford, regulatory uncertainty, loss of } \\
\text { control without loss of liability, unknown } \\
\text { waste returned (type, quantity), highest cost } \\
\text { uncertainty }\end{array}$ & $\begin{array}{l}\text { Greatest institutional benefits: } \\
\text { jobs created in community, } \\
\text { supports TRIDEC, supports } \\
\text { revitalization }\end{array}$ \\
\hline
\end{tabular}




\section{Conclusions}

Although the study summarized here focused specifically on railcars, the method developed and demonstrated in this case study can aid D\&D projects complex-wide. The key elements developed and demonstrated in this case study are as follows:

- Development of a database of information to support $D \& D$ decision-making. To construct the database, we assembled and validated cost information that currently resides in multiple printed sources. We built a database to make the assembled data available in real time to multiple users. Documented source material is scanned and made part of the database so that future users will have immediate access to source material. As the database is enlarged and refined, DOE's capabilities for $\mathrm{D} \& \mathrm{D}$ decision-making will be enhanced. By building and maintaining the database, we can provide users across the DOE complex with a source of validated cost data and save them months of time that would otherwise be spent finding and validating needed information, thereby greatly streamlining future analyses.

- Demonstration of the life cycle analysis process, including problem definition, definition of performance measures, process analysis and identification of alternatives, evaluation of alternatives, and visualization of results. Material flow diagrams, cost analysis spreadsheets, and methods used for value-of-information analysis and sensitivity and uncertainty analysis are all presented here. These same methods can be applied for D\&D decision-making complex-wide.

- Demonstration that detailed material flow diagrams are essential to the accuracy of the results. The material flow diagrams developed for this report were the result of numerous iterations with a variety of subject matter experts at the Hanford site as well as with vendors and other parties. The final results from analysis of these detailed material flow diagrams are significantly different from the initial back-of-the-envelope calculations. The approach taken here-assembling a team of subject matter experts from a wide variety of disciplines and developing detailed material flow diagrams - is highly recommended in order to have confidence in the results.

- New methods for analyzing and presenting the results of life cycle analysis that will help decision-makers make better-informed, more accurate, and more defensible decisions.

Traditional cost estimates have been based on single-point estimates. A spreadsheet model was developed that calculated the expected cost of the project. However this type of presentation, by neglecting the uncertainties involved, does not present a true picture and may lead to poor decisions. This report demonstrates how to improve the analysis of project costs by taking into consideration the uncertainty in the underlying variables. By presenting a more realistic picture of the costs of any proposal, this approach will help D\&D managers move to the next level of decision-making confidence.

The LCA system developed by ORNL's Center for Life Cycle Analysis helps the DOE make better decisions in at least three ways:

- by helping decision makers understand all impacts of decisions;

- by making the decision-making process transparent and defensible; and

- by facilitating substantive involvement in the decision-making process. 
An LCA encompasses a range of decision factors to allow decision makers to understand the complex context of their decisions. The LCA system helps to make decisions understandable and defensible by using a systematic, standardized approach and by using visualization techniques that help make the basis for the decision clear. The LCA system aids communication in public meetings by helping to focus discussions, and it facilitates the process of gaining substantive public input in decision-making. In addition, the LCA system is robust. It can be tailored to meet site and project conditions and can be applied to D\&D, pollution prevention, and asset recovery projects throughout the DOE complex. As the case study summarized here illustrates, LCA helps DOE find solutions that achieve the Department's financial, institutional, health and safety, and environmental goals. 


\section{Appendix A}

Photographs of Railcars Analyzed at Hanford 


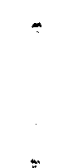



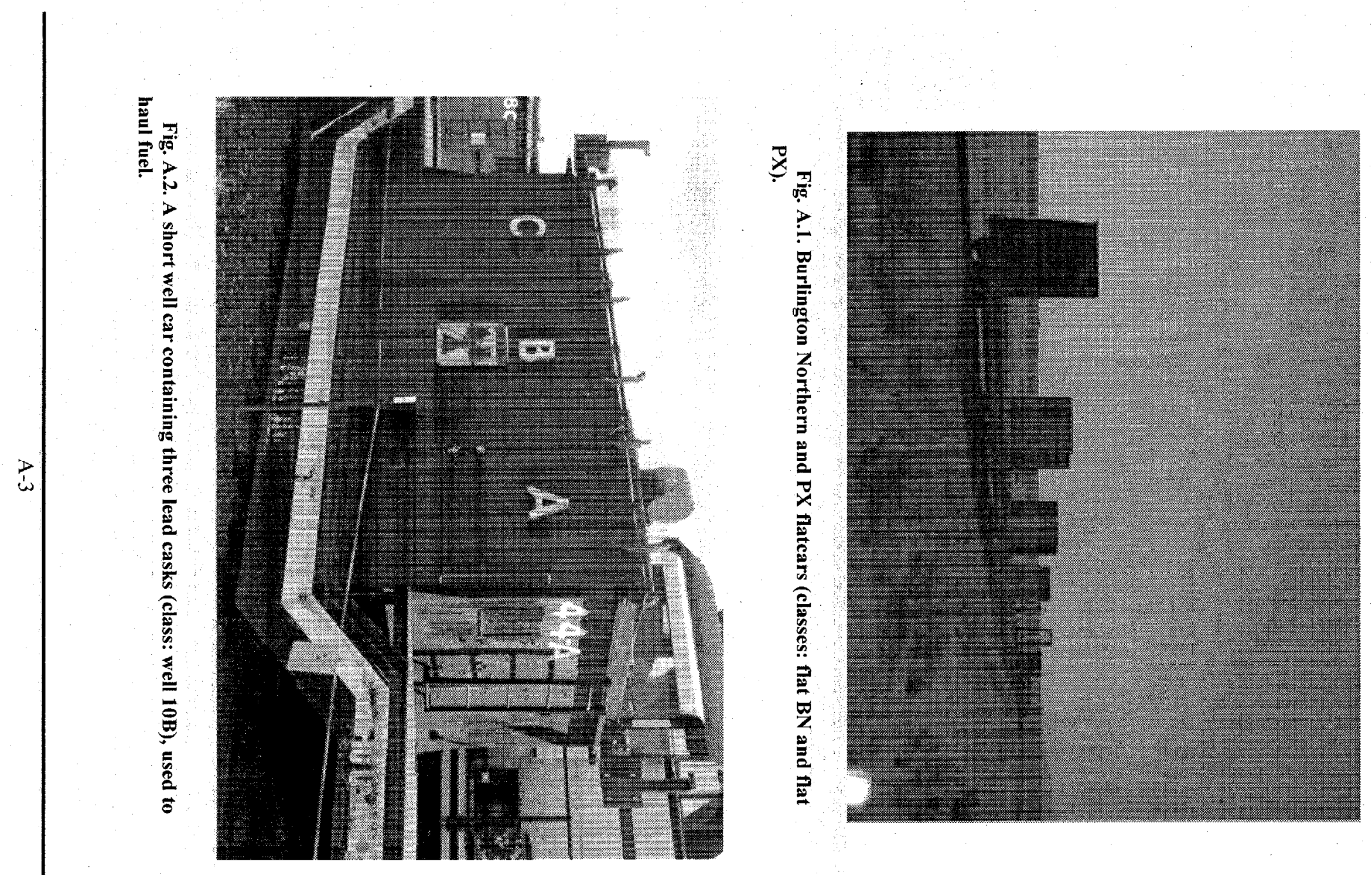


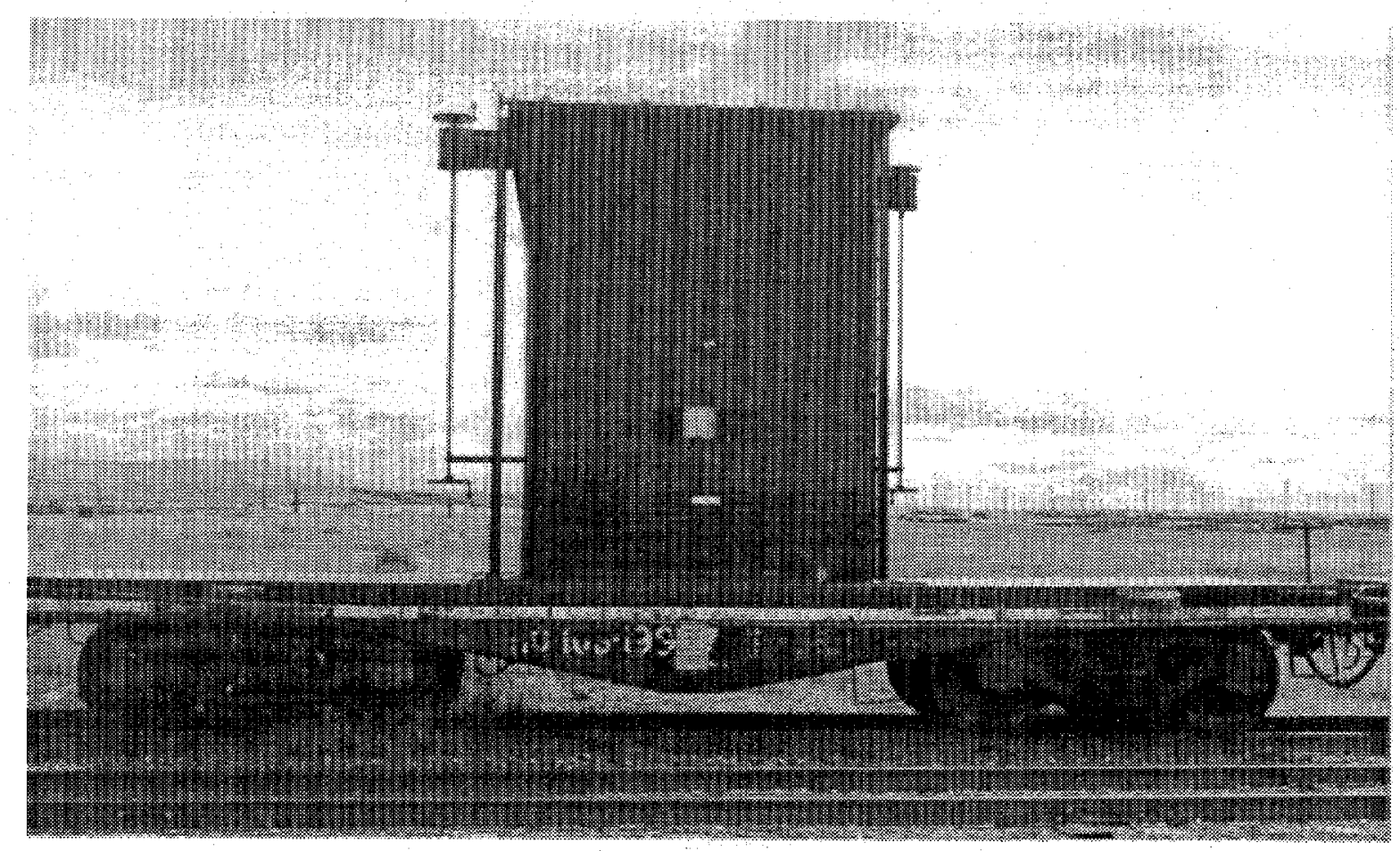

Fig. A.3. A flatcar with a single cask (class: cask 10B).

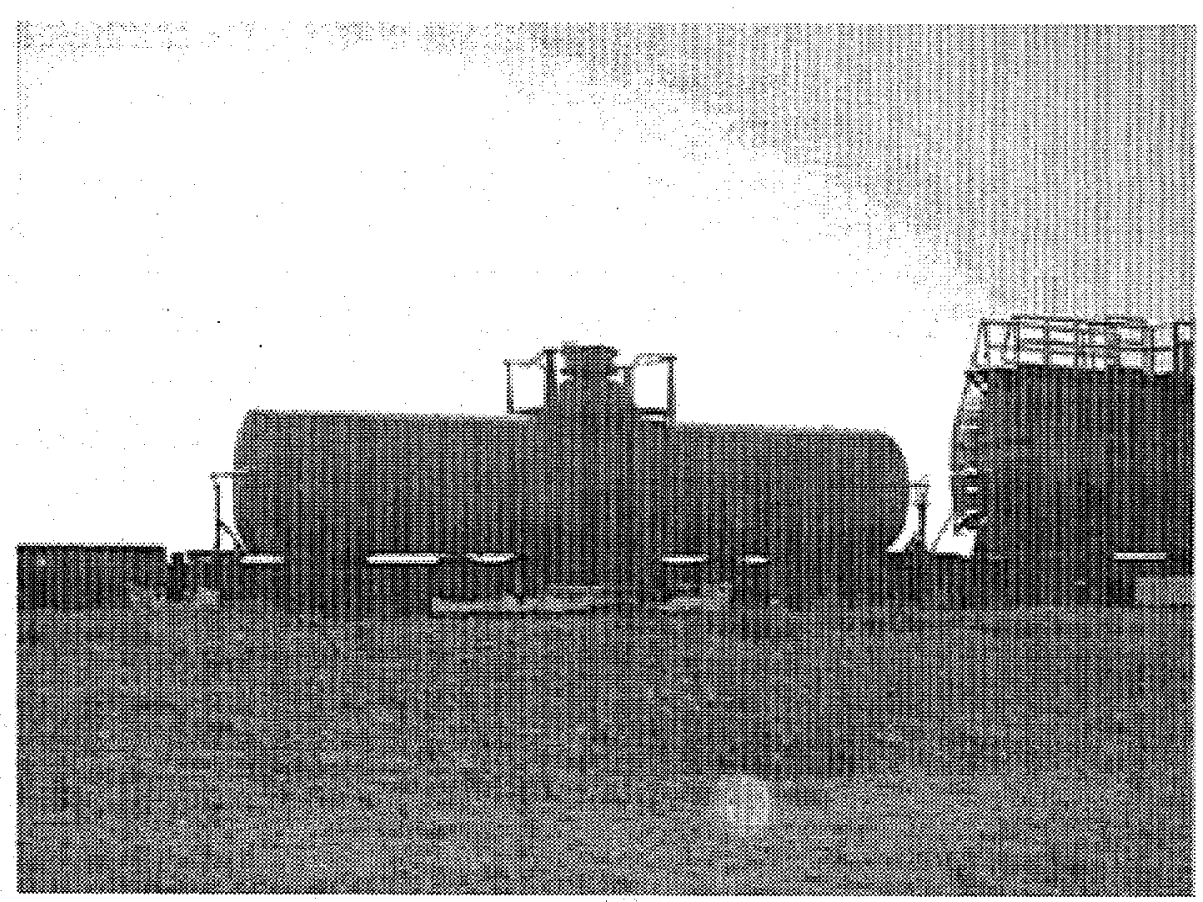

Fig. A.4. A carbon steel tank car (class: tank 10H) used to haul liquid. 


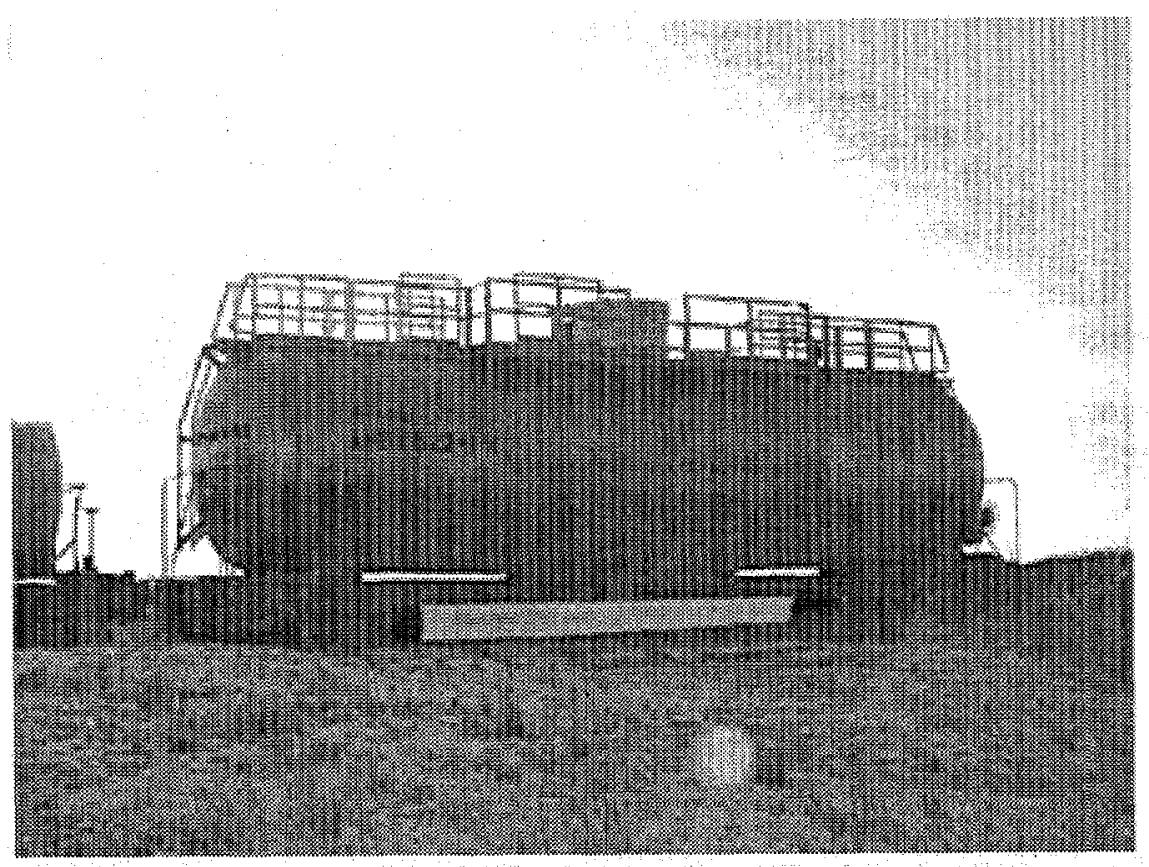

Fig. A.5. A stainless steel tank car with double-walled tank (class: tank 10A) used to haul liquid.

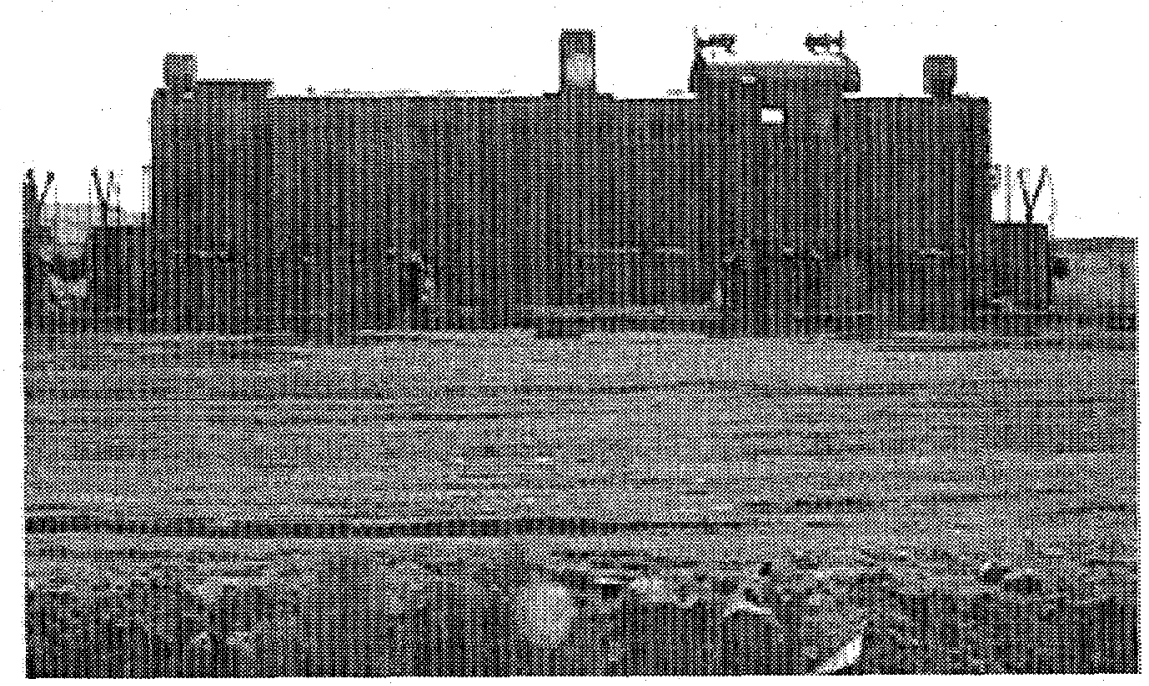

Fig. A.6. Locomotive 1. 


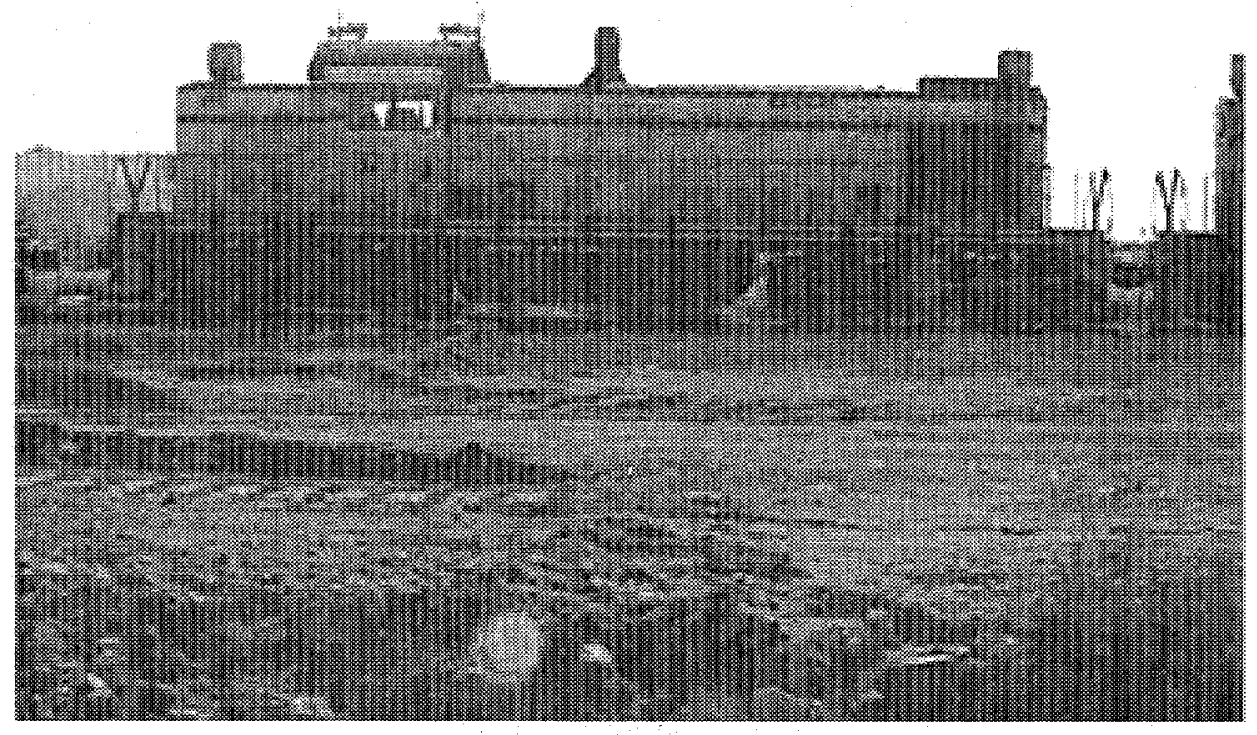

Fig. A.7. Locomotive 2. 
Appendix B

\section{Spreadsheets}



Hanford Rail Cars Alternatives: Data

\begin{tabular}{|c|c|c|c|c|c|c|c|c|}
\hline $\begin{array}{l}\text { Car Type } \\
\text { Series } \\
\text { Item }\end{array}$ & $\begin{array}{l}\text { Flat } \\
\text { BN }\end{array}$ & $\begin{array}{l}\text { Flat } \\
\text { PX }\end{array}$ & $\begin{array}{c}\text { Well Short } 3 \\
10 \mathrm{~B} \\
\end{array}$ & $\begin{array}{c}\text { Cask Tall } 1 \\
\text { 10B }\end{array}$ & $\begin{array}{c}\text { Tank } \\
10 \mathrm{H} \\
\text { Carbon Steel }\end{array}$ & $\begin{array}{c}\text { Tank } \\
\text { 10A } \\
\text { Stainless }\end{array}$ & Car Trucks & Locomotive \\
\hline Quantity & 3 & 3 & .11 & 4 & 1 & 1 & 50 & 2 \\
\hline Total Weight Ibs/car & 53,800 & 27,000 & 170,000 & 160,000 & 100,000 & 100,000 & 10,000 & 230,000 \\
\hline Metal Weight Ibs/car & 53,800 & 27,000 & 55,000 & $72 ; 000$ & 100,000 & 100,000 & 10,000 & 230,000 \\
\hline Lead Weight Ibs/car & 0 & 0 & 115,000 & 88,000 & 0 & 0 & 0 & 0 \\
\hline Total Volume $\mathrm{Ft} 3 / \mathrm{car}$ & 2,500 & 2,500 & 5,280 & 5,000 & 6,000 & 6,860 & 256 & 9,000 \\
\hline Metal Volume $\mathrm{Ft} 3 / \mathrm{car}$ & 2,500 & 2,500 & 4,980 & 4,643 & 6,000 & 6,860 & 256 & 9,000 \\
\hline Lead Volume Ft3/car & 0 & 0 & 300 & 357 & 0 & 0 & 0 & 0 \\
\hline Engineering study void space $\$ / c a r$ type & $\$ 2,000.00$ & $\$ 2,000.00$ & $\$ 30,000.00$ & $\$ 30,000.00$ & $\$ 30,000.00$ & $\$ 30,000.00$ & $\$ 2,000.00$ & $\$ 2,000,00$ \\
\hline Characterize per Car & $\$ 15,000.00$ & $\$ 15,000.00$ & $\$ 39,000.00$ & $\$ 39,000.00$ & $\$ 39,000.00$ & $\$ 39,000.00$ & $\$ 1,000.00$ & $\$ 15,000.00$ \\
\hline Crane Lift of Car $\$ /$ ift & $\$ 2,900.00$ & $\$ 2,900.00$ & $\$ 32,000.00$ & $\$ 32,000.00$ & $\$ 32,000.00$ & $\$ 32,000.00$ & $\$ 2,900.00$ & $\$ 32,000.00$ \\
\hline Separate Metal \& lead & $\$ 0.00$ & $\$ 0.00$ & $\$ 15,000.00$ & $\$ 15,000.00$ & $\$ 0.00$ & $\$ 0.00$ & $\$ 0.00$ & $\$ 0.00$ \\
\hline Package/fix contamination for Disposal \$/car & $\$ 4,000.00$ & $\$ 4,000.00$ & $\$ 10,000.00$ & $\$ 10,000.00$ & $\$ 4,000.00$ & $\$ 4,000.00$ & $\$ 2,000.00$ & $\$ 4,000.00$ \\
\hline Process lead (Macro) for Disposal $\$ /$ car & $\$ 0.00$ & $\$ 0.00$ & $\$ 60,000.00$ & $\$ 40,000,00$ & $\$ 0.00$ & $\$ 0.00$ & $\$ 0.00$ & $\$ 0.00$ \\
\hline fill void spaces for car opt $1 A^{\circ}$ & $\$ 0.00$ & $\$ 0.00$ & $\$ 30,000.00$ & $\$ 30,000.00$ & $\$ 96,000.00$ & $\$ 96,000.00$ & $\$ 0.00$ & $\$ 0.00$ \\
\hline Package fill void spaces Whole Car for Disposal opt1B & $\$ 4,000.00$ & $\$ 4,000.00$ & $\$ 30,000.00$ & $\$ 30,000.00$ & $\$ 100,000.00$ & $\$ 100,000.00$ & $\$ 2,000.00$ & $\$ 4,000.00$ \\
\hline Package Whole Car for Transport to CRO & $\$ 4,000.00$ & $\$ 4,000.00$ & $\$ 4,000.00$ & $\$ 4,000.00$ & $\$ 4,000.00$ & $\$ 4,000.00$ & $\$ 2,000.00$ & $\$ 4,000.00$ \\
\hline Package Whole Car for shipment off site & $\$ 4,000.00$ & $\$ 4,000.00$ & $\$ 4,000,00$ & $\$ 4,000.00$ & $\$ 4,000.00$ & $\$ 4,000.00$ & $\$ 2,000.00$ & $\$ 4,000,00$ \\
\hline Transport Rail Car Whole on Site & $\$ 6,000.00$ & $\$ 6,000,00$ & $\$ 6,000.00$ & $\$ 6,000.00$ & $\$ 6,000,00$ & $\$ 6,000.00$ & $\$ 3,000.00$ & $\$ 6,000.00$ \\
\hline Transport off site Broker $\$$ & $\$ 20,000.00$ & $\$ 20,000.00$ & $\$ 62,000.00$ & $\$ 62,000.00$ & $\$ 20,000.00$ & $\$ 20,000.00$ & $\$ 20,000.00$ & $\$ 20,000.00$ \\
\hline LLW Burial on-site cost $\$ / F T 3$ & $\$ 16.26$ & $\$ 16.26$ & $\$ 16.26$ & $\$ 16.26$ & $\$ 16.26$ & $\$ 16.26$ & $\$ 16.26$ & $\$ 16.26$ \\
\hline MW Burial cost on-site\$/FT3 & $\$ 127.93$ & $\$ 127.93$ & $\$ 127.93$ & $\$ 127.93$ & $\$ 127.93$ & $\$ 127.93$ & $\$ 127.93$ & $\$ 127.93$ \\
\hline Free Release Metai Scrap Cost $\$ / l b$ & $\$ 0.90$ & $\$ 0.90$ & $\$ 0.90$ & $\$ 0.90$ & $\$ 0.90$ & $\$ 0.90$ & $\$ 0.90$ & $\$ 0.90$ \\
\hline Free Release Lead Scrap Cost $\$ / b$ & $\$ 0.84$ & $\$ 0.84$ & $\$ 0.84$ & $\$ 0.84$ & $\$ 0.84$ & $\$ 0.84$ & $\$ 0.84$ & $\$ 0.84$ \\
\hline Decon FR Metal Scrap Cost $\$ / \mathrm{b}$ & $\$ 1.25$ & $\$ 1.25$ & $\$ 1.25$ & $\$ 1.25$ & $\$ 1.25$ & $\$ 1.25$ & $\$ 1.25$ & $\$ 1.25$ \\
\hline Decon FR lead Scrap Cost $\$ / \mathrm{b}$ & $\$ 1.25$ & $\$ 1.25$ & $\$ 1.25$ & $\$ 1.25$ & $\$ 1.25$ & $\$ 1.25$ & $\$ 1.25$ & $\$ 1.25$ \\
\hline Recycled Metal Melt Cost $\$ / 1 b$ & $\$ 1.65$ & $\$ 1.65$ & $\$ 1.65$ & $\$ 1.65$ & $\$ 1.65$ & $\$ 1.65$ & $\$ 1.65$ & $\$ 1.65$ \\
\hline Recycled Lead Melt Cost $\$ / \mathrm{b}$ & $\$ 1.65$ & $\$ 1.65$ & $\$ 1.65$ & $\$ 1.65$ & $\$ 1.65$ & $\$ 1.65$ & $\$ 1.65$ & $\$ 1.65$ \\
\hline Burial WAC Documentation \& Approval \$/car type & $\$ 2,000.00$ & $\$ 2,000.00$ & $\$ 20,000.00$ & $\$ 20,000.00$ & $\$ 2,000.00$ & $\$ 2,000.00$ & $\$ 1,000.00$ & $\$ 2,000.00$ \\
\hline Rail Car Sale to CRO & $\$ 0.00$ & $\$ 0.00$ & $\$ 0.00$ & $\$ 0.00$ & $\$ 0.00$ & $\$ 0.00$ & $\$ 0.00$ & $\$ 0.00$ \\
\hline Cost to Build Reprocessing Facility & $\$ 1,530,000$ & -.. & --- & --- & $\cdots$ & --- & --- & -- \\
\hline Cars sent by CRO to Metal processing vendor & 0 & 0 & 11 & 4 & 0 & 0 & 0 & 0 \\
\hline Combo Option Cars sent to disposal on site & 0 & 0 & 11 & 4 & 0 & 0 & 0 & 0 \\
\hline$\%$ metal for free release alt off site decon & $0 \%$ & $0 \%$ & $0 \%$ & $0 \%$ & $0 \%$ & $0 \%$ & $0 \%$ & $0 \%$ \\
\hline$\%$ metal for decon \& free release alt off site decon & $70 \%$ & $70 \%$ & $60 \%$ & $60 \%$ & $70 \%$ & $70 \%$ & $70 \%$ & $70 \%$ \\
\hline$\%$ metal for shield Block (Metal Melt) alt off site decon & $30 \%$ & $30 \%$ & $40 \%$ & $40 \%$ & $30 \%$ & $30 \%$ & $30 \%$ & $30 \%$ \\
\hline$\%$ metal for disposal alt off site decon & $0 \%$ & $0 \%$ & $0 \%$ & $0 \%$ & $0 \%$ & $0 \%$ & $0 \%$ & $0 \%$ \\
\hline$\%$ lead for free release alt off site decon & $100 \%$ & $100 \%$ & $100 \%$ & $100 \%$ & $100 \%$ & $100 \%$ & $100 \%$ & $100 \%$ \\
\hline$\%$ lead for decon \& free release alt off site decon & $0 \%$ & $.0 \%$ & $0 \%$ & $0 \%$ & $0 \%$ & $0 \%$ & $0 \%$ & $0 \%$ \\
\hline$\%$ Lead for shield Block (Metal Melt) alt off site decon & $0 \%$ & $0 \%$ & $0 \%$ & $0 \%$ & $0 \%$ & $0 \%$ & $0 \%$ & $0 \%$ \\
\hline$\%$ Lead for disposal alt off site decon & $0 \%$ & $0 \%$ & $0 \%$ & $0 \%$ & $0 \%$ & $0 \%$ & $0 \%$ & $0 \%$ \\
\hline$\%$ return Metal for disposal CRO option & $10 \%$ & $10 \%$ & $10 \%$ & $10 \%$ & $10 \%$ & $10 \%$ & $10 \%$ & $10 \%$ \\
\hline$\%$ return lead for dispoosal CRO option & $0 \%$ & $0 \%$ & $0 \%$ & $0 \%$ & $0 \%$ & $0 \%$ & $0 \%$ & $0 \%$ \\
\hline Project Planning $\%$ of Subtotal & $30 \%$ & $30 \%$ & $30 \%$ & $30 \%$ & $30 \%$ & $30 \%$ & $30 \%$ & $30 \%$ \\
\hline Project Management $\%$ of Subtotal & $10 \%$ & $10 \%$ & $10 \%$ & $10 \%$ & $10 \%$ & $10 \%$ & $10 \%$ & $10 \%$ \\
\hline
\end{tabular}

Value of Rail Cars after decon (ADF Steve West 9/21/99)

$\$ 25,000$

$\$ 25,000$

$\$ 250,000$

$\$ 80-\$ 100 \mathrm{~K}$ 


\section{Hanford Alternatives: Disposal 1A - Separate Metal and Lead \& Bury On-Site Separately}

\begin{tabular}{|c|c|c|c|c|c|}
\hline Item & $\begin{array}{l}\text { Flat } \\
\text { BN }\end{array}$ & $\begin{array}{l}\text { Flat } \\
\text { PX }\end{array}$ & $\begin{array}{l}\text { Well } \\
10 \mathrm{~B}\end{array}$ & $\begin{array}{c}\text { Cask } \\
10 B\end{array}$ & $\begin{array}{c}\text { Tank } \\
10 \mathrm{H}\end{array}$ \\
\hline Quantity & 3 & 3 & 11 & 4 & 1 \\
\hline Total Weight Ibs & 161,400 & 81,000 & $1,870,000$ & 640,000 & 100,000 \\
\hline Metal Weight Ibs & 161,400 & 81,000 & 605,000 & 288,000 & 100,000 \\
\hline Lead Weight lbs & 0 & 0 & $1,265,000$ & 352,000 & 0 \\
\hline Total Volume Ft3 & 7,500 & 7,500 & 58,080 & 20,000 & 6,000 \\
\hline Metal Volume Ft3 & 7,500 & 7,500 & 54,780 & 18,572 & 6,000 \\
\hline Lead Volume Ft3 & 0 & 0 & 3,300 & 1,428 & 0 \\
\hline Costs: & - & ---- & …… & - & ----' \\
\hline Characterize & $\$ 45,000$ & $\$ 45,000$ & $\$ 429,000$ & $\$ 156,000$ & $\$ 39,000$ \\
\hline Engineering Study Voids & $\$ 2,000$ & $\$ 2,000$ & $\$ 30,000$ & $\$ 30,000$ & $\$ 30,000$ \\
\hline Lift Car & $\$ 17,400$ & $\$ 17,400$ & $\$ 704,000$ & $\$ 256,000$ & $\$ 64,000$ \\
\hline Separate Metal and lead & $\$ 0$ & So & $\$ 165,000$ & $\$ 60,000$ & $\$ 0$ \\
\hline Package/fix contamination Metal \& lead & $\$ 12,000$ & $\$ 12,000$ & $\$ 110,000$ & $\$ 40,000$ & $\$ 4,000$ \\
\hline Transport Metal and Lead & $\$ 18,000$ & $\$ 18,000$ & $\$ 66,000$ & $\$ 24,000$ & $\$ 6,000$ \\
\hline Process Lead Macroencapsulate & $\$ 0$ & \$o & $\$ 660,000$ & $\$ 160,000$ & $\$ 0$ \\
\hline Fill Void spaces & $\$ 0$ & So & $\$ 330,000$ & $\$ 120,000$ & $\$ 96,000$ \\
\hline WAC Validation Package & $\$ 6,000$ & $\$ 6,000$ & $\$ 220,000$ & $\$ 80,000$ & $\$ 2,000$ \\
\hline Disposal LLW & $\$ 121,950$ & $\$ 121,950$ & $\$ 890,723$ & $\$ 301,981$ & $\$ 97,560$ \\
\hline Disposal MW & \$o & so & $\$ 422,169$ & $\$ 182,684$ & $\$ 0$ \\
\hline Sub Total Costs & $\$ 222,350$ & $\$ 222,350$ & $\$ 4,026,892$ & $\$ 1,410,665$ & $\$ 338,560$ \\
\hline Project Plan as \% of ST & $\$ 66,705$ & $\$ 66,705$ & $\$ 1,208,068$ & $\$ 423,199$ & $\$ 101,568$ \\
\hline Project Management as $\%$ of ST & $\$ 22,235$ & $\$ 22,235$ & $\$ 402,689$ & $\$ 141,066$ & $\$ 33,856$ \\
\hline Total $\quad \cdots$ & $\$ 311,290$ & $\$ 311,290$ & $\$ 5,637,649$ & $\$ 1,974,931$ & $\$ 473,984$ \\
\hline Cost/Car & $\$ 103,763$ & $\$ 103,763$ & $\$ 512,514$ & $\$ 493,733$ & $\$ 473,984$ \\
\hline
\end{tabular}

\begin{tabular}{|c|c|c|c|c|c|}
\hline Item & & $\begin{array}{l}\text { Tank } \\
10 \mathrm{~A}\end{array}$ & Car Trucks & Locomotive & $\cdots$ Total \\
\hline Quantity & & 1 & 50 & 2 & 75 \\
\hline Total Weight tbs & & 100,000 & 500,000 & 460,000 & $3,912,400$ \\
\hline Metal Weight Ibs & & 100,000 & 500,000 & 460,000 & $2,295,400$ \\
\hline Lead Weight Ibs & & 0 & 0 & 0 & $1,617,000$ \\
\hline Total Volume Ft3 & & 6,860 & 12,800 & 18,000 & 136,740 \\
\hline Metal Volume Ft3 & & 6,860 & 12,800 & 18,000 & 132,012 \\
\hline Lead Volume Ft3 & & 0 & 0 & 0 & 4,728 \\
\hline Costs: & & ----- & - & ב-ב- & Cost Totals \\
\hline Characterize & & $\$ 39,000$ & $\$ 50,000$ & $\$ 30,000$ & $\$ 833,000$ \\
\hline Engineering Study Voids & & $\$ 30,000$ & $\$ 2,000$ & $\$ 2,000$ & $\$ 128,000$ \\
\hline Lift Car & & $\$ 64,000$ & $\$ 145,000$ & $\$ 128,000$ & $\$ 1,395,800$ \\
\hline Separate Metal and lead & & $\$ 0$ & \$o & $\$ 0$ & $\$ 225,000$ \\
\hline Package/fix contamination Metal \& lead & & $\$ 4,000$ & $\$ 100,000$ & $\$ 8,000$ & $\$ 290,000$ \\
\hline Transport Metal and Lead & & $\$ 6,000$ & $\$ 150,000$ & $\$ 12,000$ & $\$ 300,000$ \\
\hline Process Lead Macroencapsulate & . & $\$ 0$ & $\$ 0$ & $\$ 0$ & $\$ 820,000$ \\
\hline Fill Void spaces & & $\$ 96,000$ & So & $\$ 0$ & $\$ 642,000$ \\
\hline WAC Validation Package & & $\$ 2,000$ & $\$ 50,000$ & $\$ 4,000$ & $\$ 370,000$ \\
\hline Dlsposal LLW & & $\$ 111,544$ & $\$ 208,128$ & $\$ 292,680$ & $\$ 2,146,515$ \\
\hline Disposal MW & & \$o & So & $\$ 0$ & $\$ 604,853$ \\
\hline Sub Total Costs & & $\$ 352,544$ & $\$ 705,128$ & $\$ 476,680$ & $\$ 7,755,168$ \\
\hline Project Plan as $\%$ of ST & & $\$ 105,763$ & $\$ 211,538$ & $\$ 143,004$ & $\$ 2,326,550$ \\
\hline Project Management as $\%$ of ST & & $\$ 35,254$ & $\$ 70,513$ & $\$ 47,668$ & $\$ 775,517$ \\
\hline Total: $\quad$ s & & $\$ 493,561$ & $\$ 987179$ & $\$ 667,352$ & $\$ 10,857,235$ \\
\hline Total Cost/Ca:r & & $\$ 493,561$ & $\$ 19,744$ & $\$ 333,676$ & \\
\hline
\end{tabular}

Cost to Build Facility: $\$ 1,530,000$

Grand Total Cost With Facility:

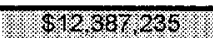




\section{Hanford Alternatives: Disposal 1B - Dispose of Cars On-Site Intact}

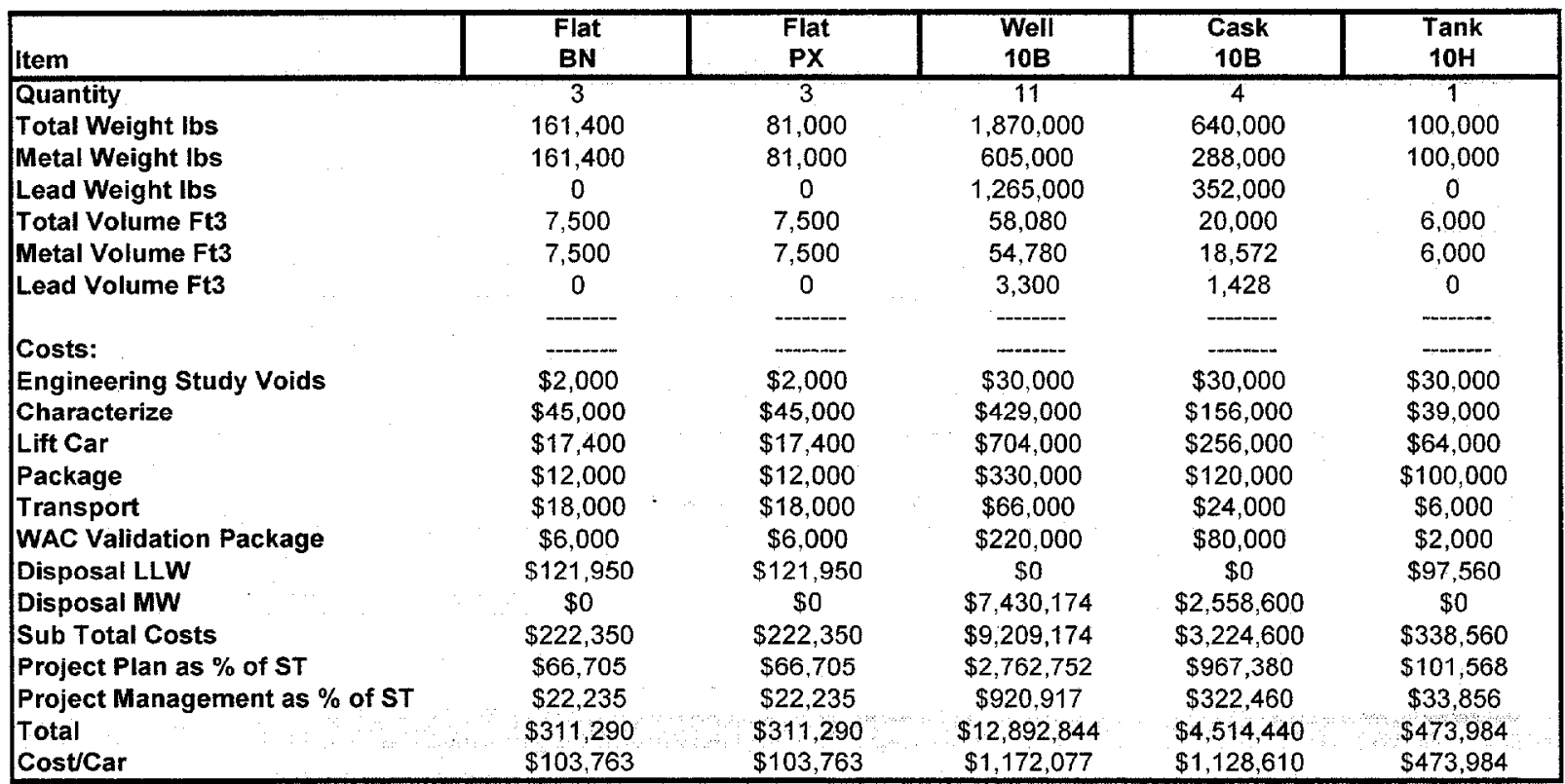

\begin{tabular}{|c|c|c|c|c|}
\hline Item & $\begin{array}{c}\text { Tank } \\
10 \mathrm{~A}\end{array}$ & Car Trucks & Locomotive & Total \\
\hline Quantity & 1 & 50 & 2 & 75 \\
\hline Total Weight Ibs & 100,000 & 500,000 & 460,000 & $3,912,400$ \\
\hline Metal Weight Ibs & 100,000 & 500,000 & 460,000 & $2,295,400$ \\
\hline Lead Weight Ibs & 0 & 0 & 0 & $1,617,000$ \\
\hline Total Volume Ft3 & 6,860 & 12,800 & 18,000 & 136,740 \\
\hline Metal Volume Ft3 & 6,860 & 12,800 & 18,000 & 132,012 \\
\hline Lead Volume Ft3 & 0 & 0 & 0 & 4,728 \\
\hline Costs: & -..-- & - n-1..- & - n & Cost Totals \\
\hline Engineering Study Voids & $\$ 30,000$ & $\$ 2,000$ & $\$ 2,000$ & $\$ 128,000$ \\
\hline Characterize & $\$ 39,000$ & $\$ 50,000$ & $\$ 30,000$ & $\$ 833,000$ \\
\hline Lift Car & $\$ 64,000$ & $\$ 145,000$ & $\$ 128,000$ & $\$ 1,395,800$ \\
\hline Package & $\$ 100,000$ & $\$ 100,000$ & $\$ 8,000$ & $\$ 782,000$ \\
\hline Transport & $\$ 6,000$ & $\$ 150,000$ & $\$ 12,000$ & $\$ 300,000$ \\
\hline WAC Validation Package & $\$ 2,000$ & $\$ 50,000$ & $\$ 4,000$ & $\$ 370,000$ \\
\hline Disposal LLW & $\$ 111,544$ & $\$ 208,128$ & $\$ 292,680$ & $\$ 953,812$ \\
\hline Disposal MW & $\$ 0$ & $\$ 0$ & \$O & $\$ 9,988,774$ \\
\hline Sub Total Costs & $\$ 352,544$ & $\$ 705,128$ & $\$ 476,680$ & $\$ 14,751,386$ \\
\hline Project Plan as $\%$ of ST & $\$ 105,763$ & $\$ 211,538$ & $\$ 143,004$ & $\$ 4,425,416$ \\
\hline Project Management as $\%$ of ST & $\$ 35,254$ & $\$ 70,513$ & $\$ 47,668$ & $\$ 1,475,139$ \\
\hline Total: $\quad$ a & $\$ 493,561$ & $\$ 987179$ & $\$ 667,352$ & $\$ 20,651,940$ \\
\hline Total Cost/Ca:r & $\$ 493,561$ & $\$ 19,744$ & $\$ 333,676$ & \\
\hline
\end{tabular}

Cost to Bulld Facility:

$\$ 1,530,000$

Grand Total Cost With Facility: 


\section{Hanford Alternatives: Off-Site Vendor Decontamination \& Release of Metal and Lead}

\begin{tabular}{|c|c|c|c|c|c|}
\hline $\begin{array}{l}\text { Item } \\
\text { Item }\end{array}$ & $\begin{array}{l}\text { Flat } \\
\text { BN }\end{array}$ & $\begin{array}{l}\text { Flat } \\
\text { PX }\end{array}$ & $\begin{array}{l}\text { Well } \\
10 \mathrm{~B}\end{array}$ & $\begin{array}{l}\text { Cask } \\
10 \mathrm{~B}\end{array}$ & $\begin{array}{l}\text { Tank } \\
10 \mathrm{H}\end{array}$ \\
\hline Quantity & 3 & 3 & 11 & 4 & 1 \\
\hline Total Weight lbs & 161,400 & 81,000 & $1,870,000$ & 640,000 & 100,000 \\
\hline Metal Weight Ibs & 161,400 & 81,000 & 605,000 & 288,000 & 100,000 \\
\hline Lead Weight Ibs & 0 & 0 & $1,265,000$ & 352,000 & 0 \\
\hline Total Volume Ft3 & 7,500 & 7,500 & 58,080 & 20,000 & 6,000 \\
\hline Metal Volume Ft3 & 7,500 & 7,500 & 54,780 & 18,572 & 6,000 \\
\hline Lead Volume Ft3 & 0 & 0 & 3,300 & 1,428 & 0 \\
\hline Costs: & - & ------- & --.-- & --- & -+- \\
\hline Characterize & $\$ 45,000$ & $\$ 45,000$ & $\$ 429,000$ & $\$ 156,000$ & $\$ 39,000$ \\
\hline Lift Car & $\$ 17,400$ & $\$ 17,400$ & $\$ 352,000$ & $\$ 128,000$ & $\$ 32,000$ \\
\hline Package & $\$ 12,000$ & $\$ 12,000$ & $\$ 44,000$ & $\$ 16,000$ & $\$ 4,000$ \\
\hline Transport Via Broker & $\$ 60,000$ & $\$ 60,000$ & $\$ 682,000$ & $\$ 248,000$ & $\$ 20,000$ \\
\hline Metal for free release & \$O & $\$ 0$ & \$0 & $\$ 0$ & SO \\
\hline Metal for decon \& free release & $\$ 141,225$ & $\$ 70,875$ & $\$ 453,750$ & $\$ 216,000$ & $\$ 87,500$ \\
\hline Metal for shield Block (Metal Melt) & $\$ 79,893$ & $\$ 40,095$ & $\$ 399,300$ & $\$ 190,080$ & $\$ 49,500$ \\
\hline Metal for disposal & $\$ 0$ & $\$ 0$ & $\$ 0$ & $\$ 0$ & $\$ 0$ \\
\hline Lead for free release & $\$ 0$ & $\$ 0$ & $\$ 1,062,600$ & $\$ 295,680$. & So \\
\hline Lead for decon $\&$ free release & $\$ 0$ & $\$ 0$ & $\$ 0$ & $\$ 0$ & So \\
\hline Lead for shield Block (Metal Melt) & $\$ 0$ & $\$ 0$ & $\$ 0$ & $\$ 0$ & so \\
\hline Lead for disposal & $\$ 0$ & $\$ 0$ & \$o & $\$ 0$ & \$o \\
\hline Sub Total Costs & $\$ 355,518$ & $\$ 245,370$ & $\$ 3,422,650$ & $\$ 1,249,760$ & $\$ 232,000$ \\
\hline Project Plan as \% of ST & $\$ 22,320$ & $\$ 22,320$ & $\$ 247,500$ & $\$ 90,000$ & $\$ 22,500$ \\
\hline Project Management as $\%$ of ST & $\$ 35,552$ & $\$ 24,537$ & $\$ 342,265$ & $\$ 124,976$ & $\$ 23,200$ \\
\hline Total & $\$ 413,390$ & $\$ 292,227$ & $\$ 4,012,415$ & $\$ 1,464,736$ & $\$ 277,700$ \\
\hline Cost/Car & $\$ 137,797$ & $\$ 97,409$ & $\$ 364,765$ & $\$ 366,184$ & $\$ 277,700$ \\
\hline
\end{tabular}

\begin{tabular}{|c|c|c|c|c|}
\hline Item & $\begin{array}{c}\text { Tank } \\
\text { 10A }\end{array}$ & Car Trucks & Locomotive & Total \\
\hline Quantity & 1 & 50 & 2 & 75 \\
\hline Total Weight Ibs & 100,000 & 500,000 & 460,000 & $3,912,400$ \\
\hline Metal Weight Ibs & 100,000 & 500,000 & 460,000 & $2,295,400$ \\
\hline Lead Weight Ibs & 0 & 0 & 0 & $1,617,000$ \\
\hline Total Volume Ft3 & 6,860 & 12,800 & 18,000 & 136,740 \\
\hline Metal Volume Ft3 & 6,860 & 12,800 & 18,000 & 132,012 \\
\hline Lead Volume Ft3 & 0 & 0 & 0 & 4,728 \\
\hline Costs: & - & --.m- & --.-- & Cost Totals \\
\hline Characterize & $\$ 39,000$ & $\$ 50,000$ & $\$ 30,000$ & $\$ 833,000$ \\
\hline Lift Car & $\$ 32,000$ & $\$ 145,000$ & $\$ 64,000$ & $\$ 787,800$ \\
\hline Package & $\$ 4,000$ & $\$ 100,000$ & $\$ 8,000$ & $\$ 200,000$ \\
\hline Transport Via Broker & $\$ 20,000$ & $\$ 1,000,000$ & $\$ 40,000$ & $\$ 2,130,000$ \\
\hline Metal for free release & $\$ 0$ & $\$ 0$ & $\$ 0$ & $\$ \mathrm{SO}$ \\
\hline Metal for decon \& free release & $\$ 87,500$ & $\$ 437,500$ & $\$ 402,500$ & $\$ 1,896,850$ \\
\hline Metal for shield Block (Metal Melt) & $\$ 49,500$ & $\$ 247,500$ & $\$ 227,700$ & $\$ 1,283,568$ \\
\hline Metal for disposal & $\$ 0$ & $\$ 0$ & \$0 & $\$ 0$ \\
\hline Lead for free release & $\$ 0$ & $\$ 0$ & \$o & $\$ 1,358,280$ \\
\hline Lead for decon \& free release & $\$ 0$ & $\$ 0$ & $\$ 0$ & SO \\
\hline Lead for shield Block (Metal Melt) & $\$ 0$ & $\$ 0$ & $\$ 0$ & $\$ 0$ \\
\hline Lead for disposal & $\$ 0$ & $\$ 0$ & \$0 & ४\$o \\
\hline Sub Total Costs & $\$ 232,000$ & $\$ 1,980,000$ & $\$ 772,200$ & $\$ 8,489,498$ \\
\hline Project Plan as \% of ST & $\$ 22,500$ & $\$ 88,500$ & $\$ 30,600$ & $\$ 546,240$ \\
\hline Project Management as \% of ST & $\$ 23,200$ & $\$ 198,000$ & $\$ 77,220$ & $\$ 848,950$ \\
\hline Total: & $\$ 277,700$ & $\$ 2,266,500$ & $\$ 880,020$ & $\$ 9,884,688$ \\
\hline Total Cost/Ca:r & $\$ 277,700$ & $\$ 45,330$ & $\$ 440,010$ & \\
\hline
\end{tabular}

Cost to Build Facility: $\$ 1,530,000$

Grand Total Cost With Facility: 
Hanford Alternatives: Combination CRO \& Off-Site Vendor Processing

\begin{tabular}{|c|c|c|c|c|c|}
\hline Item & $\begin{array}{l}\text { Flat } \\
\text { BN }\end{array}$ & $\begin{array}{l}\text { Flat } \\
\text { PX }\end{array}$ & $\begin{array}{l}\text { Well } \\
\text { 10B }\end{array}$ & $\begin{array}{c}\text { Cask } \\
10 B\end{array}$ & $\begin{array}{c}\text { Tank } \\
10 \mathrm{H}\end{array}$ \\
\hline Quantity & 3 & 3 & 11 & 4 & 1 \\
\hline Total Weight Ibs & 161,400 & 81,000 & $1,870,000$ & 640,000 & 100,000 \\
\hline Metal Weight Ibs & 161,400 & 81,000 & 605.000 & 288,000 & 100,000 \\
\hline Lead Weight lbs & 0 & 0 & $1,265.000$ & 352,000 & 0 \\
\hline Total Volume Ft3 & 7,500 & 7,500 & 58,080 & 20,000 & 6,000 \\
\hline Metal Volume Ft3 & 7,500 & 7,500 & 54.780 & 18,572 & 6,000 \\
\hline Lead Volume Ft3 & 0 & 0 & 3,300 & 1,428 & 0 \\
\hline Cars Sent to Metal Processing Vendor (MPV) & 0 & 0 & 11 & 4 & 0 \\
\hline & --M- & - & -.-.-..-- & ------- & ---- \\
\hline $\begin{array}{l}\text { Costs: } \\
\text { Characterize }\end{array}$ & $\$ 45,000$ & $\$ 45,000$ & $\$ 429.000$ & $\$ 156,000$ & $\$ 39,000$ \\
\hline Lift Car & $\$ 17,400$ & $\$ 17,400$ & $\$ 352,000$ & $\$ 128,000$ & $\$ 32,000$ \\
\hline Package & $\$ 12,000$ & $\$ 12,000$ & $\$ 44,000$ & $\$ 16,000$ & $\$ 4,000$ \\
\hline Transport On Site to CRO & $\$ 18,000$ & $\$ 18,000$ & $\$ 66,000$ & $\$ 24,000$ & $\$ 6,000$ \\
\hline Sale to CRO & \$o & $\$ 0$ & $\$ 0$ & \$O & SO \\
\hline Cars sent to Metal Processing Vendor (MPV) & $\$ 0$ & $\$ 0$ & $\$ 763,978$ & $\$ 375.882$ & \$o \\
\hline Fuel Containers sent to MPV & - & - & $\$ 1,744,600$ & $\$ 543,680$ & - \\
\hline Metal for Return \& Disposal & $\$ 12,195$ & $\$ 12,195$ & $\$ 89,072$ & $\$ 30,198$ & $\$ 9,756$ \\
\hline Sub Total Costs & $\$ 104,595$ & $\$ 104,595$ & $\$ 3,488,650$ & $\$ 1,273,760$ & $\$ 90,756$ \\
\hline Project Plan as \% of ST & $\$ 27,720$ & $\$ 27,720$ & $\$ 267,300$ & $\$ 97,200$ & $\$ 24,300$ \\
\hline Project Management as \% of ST & $\$ 10,460$ & $\$ 10,460$ & $\$ 348,865$ & $\$ 127.376$ & $\$ 9,076$ \\
\hline Total & $\$ 142,775$ & $\$ 142,775$ & $\$ 4,104,815$ & $\$ 1,498,336$ & $\$ 124,132$ \\
\hline Cost/Car & $\$ 47,592$ & $\$ 47,592$ & $\$ 373,165$ & $\$ 374,584$ & $\$ 124,132$ \\
\hline
\end{tabular}

\begin{tabular}{|c|c|c|c|c|}
\hline Item & $\begin{array}{c}\text { Tank } \\
10 A\end{array}$ & Car Trucks & Locomotive & Total \\
\hline Quantity & 1 & 50 & 2 & 75 \\
\hline Total Weight lbs & 100,000 & 500,000 & 460,000 & $3,912,400$ \\
\hline Metal Weight Ibs & 100,000 & 500,000 & 460,000 & $2,295,400$ \\
\hline Lead Weight Ibs & 0 & 0 & 0 & $1,617,000$ \\
\hline Total Volume Ft3 & 6,860 & 12,800 & 18,000 & 136,740 \\
\hline Metal Volume Ft3 & 6,860 & 12,800 & 18,000 & 132,012 \\
\hline Lead Volume Ft3 & 0 & 0 & 0 & 4,728 \\
\hline Cars Sent to Metal Processing Vendor (MPV) & 0 & 0 & 0 & 15 \\
\hline Costs: & 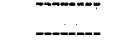 & - & $\ldots$ & Cost Totals \\
\hline Characterize & $\$ 39,000$ & $\$ 50,000$ & $\$ 30,000$ & $\$ 833,000$ \\
\hline Lift Car & $\$ 32,000$ & $\$ 145,000$ & $\$ 64,000$ & $\$ 787,800$ \\
\hline Package & $\$ 4,000$ & $\$ 100,000$ & $\$ 8,000$ & $\$ 200,000$ \\
\hline Transport On Site to CRO & $\$ 6,000$ & $\$ 150,000$ & $\$ 12,000$ & $\$ 300 ; 000$ \\
\hline Sale to CRO & $\$ 0$ & $\$ 0$ & $\$ 0$ & $\$ 0$ \\
\hline Cars sent to Metal Processing Vendor (MPV) & $\$ 0$ & $\$ 0$ & $\$ 0$ & $\$ 1,139,860$ \\
\hline Fuel Containers sent to MPV & - & - & - & $\$ 2,288,280$ \\
\hline Metal for Return \& Disposal & $\$ 11,154$ & $\$ 20,813$ & $\$ 29,268$ & $\$ 214,652$ \\
\hline Sub Total Costs & $\$ 92,154$ & $\$ 465,813$ & $\$ 143,268$ & $\$ 5,763,591$ \\
\hline Project Plan as \% of ST & $\$ 24,300$ & $\$ 133,500$ & $\$ 34,200$ & $\$ 636,240$ \\
\hline Project Management as $\%$ of ST & $\$ 9,215$ & $\$ 46,581$ & $\$ 14,327$ & $\$ 576,359$ \\
\hline Total: & $\$ 125,670$ & $\$ 645,894$ & $\$ 191,795$ & $\$ 6,976,190$ \\
\hline Total Cost/Ca:r & $\$ 125,670$ & $\$ 12,918$ & $\$ 95,897$ & \\
\hline Cost to Build Facility: & $\$ 1,530,000$ & & & \\
\hline Grand Total Cost With Facility: & S6.516.99 & & & \\
\hline
\end{tabular}


Hanford Alternatives: Combination CRO \& On Site Disposal Option 1A

\begin{tabular}{|c|c|c|c|c|c|}
\hline Item & $\begin{array}{l}\text { Flat } \\
\text { BN }\end{array}$ & $\begin{array}{c}\text { Flat } \\
\text { PX }\end{array}$ & $\begin{array}{l}\text { Well } \\
10 \mathrm{~B}\end{array}$ & $\begin{array}{c}\text { Cask } \\
10 \mathrm{~B}\end{array}$ & $\begin{array}{c}\text { Tank } \\
10 \mathrm{H}\end{array}$ \\
\hline Quantity & 3 & 3 & 11 & 4 & 1 \\
\hline Total Weight lbs & 161,400 & 81,000 & $1,870,000$ & 640,000 & 100,000 \\
\hline Metal Weight Ibs & 161,400 & 81,000 & 605,000 & 288,000 & 100,000 \\
\hline Lead Weight Ibs & 0 & 0 & $1,265,000$ & 352,000 & 0 \\
\hline Total Volume Ft3 & 7,500 & 7,500 & 58,080 & 20,000 & 6,000 \\
\hline Metal Volume Ft3 & 7,500 & 7,500 & 54,780 & 18,572 & 6,000 \\
\hline Lead Volume Ft3 & 0 & 0 & 3,300 & 1,428 & 0 \\
\hline Car Sent for Disposal on Site & 0 & 0 & 11 & 4 & 0 \\
\hline Costs: & 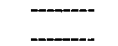 & ------ & יחי & ------ & --- \\
\hline Characterize & $\$ 45,000$ & $\$ 45,000$ & $\$ 429,000$ & $\$ 156,000$ & $\$ 39,000$ \\
\hline Lift Car & $\$ 17,400$ & $\$ 17,400$ & $\$ 352,000$ & $\$ 128,000$ & $\$ 32,000$ \\
\hline Package & $\$ 12,000$ & $\$ 12,000$ & $\$ 0$ & $\$ 0$ & $\$ 4,000$ \\
\hline Transport On Site to CRO & $\$ 18,000$ & $\$ 18,000$ & \$0 & $\$ 0$ & $\$ 6,000$ \\
\hline Sale to CRO & $\$ 0$ & $\$ 0$ & $\$ 0$ & $\$ 0$ & $\$ 0$ \\
\hline CRO Waste for Return \& Disposal & $\$ 12,195$ & $\$ 12,195$ & \$O & $\$ 0$ & $\$ 9,756$ \\
\hline Engineering Study Voids & $\$ 0$ & $\$ 0$ & $\$ 30,000$ & $\$ 30,000$ & \$o \\
\hline Lift Car & $\$ 0$ & $\$ 0$ & $\$ 352,000$ & $\$ 128,000$ & $\$ 0$ \\
\hline Separate Metal and lead & $\$ 0$ & $\$ 0$ & $\$ 165,000$ & $\$ 60,000$ & $\$ 0$ \\
\hline Package/fix contamination Metal \& lead & $\$ 0$ & $\$ 0$ & $\$ 110,000$ & $\$ 40,000$ & $\$ 0$ \\
\hline Transport Metal and Lead & $\$ 0$ & $\$ 0$ & $\$ 66,000$ & $\$ 24,000$ & $\$ 0$ \\
\hline Process Lead Macroencapsulate & $\$ 0$ & $\$ 0$ & $\$ 660,000$ & $\$ 160,000$ & $\$ 0$ \\
\hline Fill Void spaces & $\$ 0$ & $\$ 0$ & $\$ 330,000$ & $\$ 120,000$ & $\$ 0$ \\
\hline WAC Validation Package & $\$ 0$ & $\$ 0$ & $\$ 220,000$ & $\$ 80,000$ & $\$ 0$ \\
\hline Disposal LLW & $\$ 12,195$ & $\$ 12,195$ & $\$ 890,723$ & $\$ 301,981$ & $\$ 9,756$ \\
\hline Disposal MW & $\$ 0$ & $\$ 0$ & $\$ 422,169$ & $\$ 182.684$ & $\$ 0$ \\
\hline Sub Total Costs & $\$ 116,790$ & $\$ 116,790$ & $\$ 4,026,892$ & $\$ 1,410,665$ & $\$ 100,512$ \\
\hline Project Plan as $\%$ of ST & $\$ 35,037$ & $\$ 35,037$ & $\$ 1,208,068$ & $\$ 423,199$ & $\$ 30,154$ \\
\hline Project Management as $\%$ of ST & $\$ 11,679$ & $\$ 11,679$ & $\$ 402,689$ & $\$ 141,066$ & $\$ 10,051$ \\
\hline Total & $\$ 163,506$ & $\$ 163,506$ & $\$ 5,637,649$ & $\$ 1,974,931$ & $\$ 140,717$ \\
\hline Cost/Car & $\$ 54,502$ & $\$ 54,502$ & $\$ 512,514$ & $\$ 493,733$ & $\$ 140,717$ \\
\hline
\end{tabular}

\begin{tabular}{|c|c|c|c|c|}
\hline Item & $\begin{array}{c}\text { Tank } \\
10 \mathrm{~A}\end{array}$ & Car Trucks & Locomotive & Total \\
\hline Quantity & 1 & 50 & 2 & 75 \\
\hline Total Weight Ibs & 100,000 & 500,000 & 460,000 & $3,912,400$ \\
\hline Metal Weight Ibs & 100,000 & 500,000 & 460,000 & $2,295,400$ \\
\hline Lead Weight Ibs & 0 & 0 & 0 & $1,617,000$ \\
\hline Total Volume $\mathrm{Ft} 3$ & 6,860 & 12,800 & 18,000 & 136,740 \\
\hline Metal Volume Ft3 & 6,860 & 12,800 & 18,000 & 132,012 \\
\hline Lead Volume Ft3 & 0 & 0 & 0 & 4,728 \\
\hline Car Sent for Disposal on Site & 0 & 0 & 0 & 15 \\
\hline Costs: & - n-- & ---- & $\ldots$ & Cost Totals \\
\hline Characterize & $\$ 39,000$ & $\$ 50,000$ & $\$ 30,000$ & $\$ 833,000$ \\
\hline Lift Car & $\$ 32,000$ & $\$ 145,000$ & $\$ 64,000$ & $\$ 787,800$ \\
\hline Package & $\$ 4,000$ & $\$ 100,000$ & $\$ 8,000$ & $\$ 140,000$ \\
\hline Transport On Site to CRO & $\$ 6,000$ & $\$ 150,000$ & $\$ 12,000$ & $\$ 210,000$ \\
\hline Sale to CRO & $\$ 0$ & \$0 & $\$ 0$ & $\$ 0$ \\
\hline CRO Waste for Return \& Disposal & $\$ 11,154$ & $\$ 20,813$ & $\$ 29,268$ & $\$ 95,381$ \\
\hline Engineering Study Voids & \$o & $\$ 0$ & $\$ 0$ & $\$ 60,000$ \\
\hline Lift Car & $\$ 0$ & $\$ 0$ & $\$ 0$ & $\$ 480 ; 000$ \\
\hline Separate Metal and lead & $\$ 0$ & $\$ 0$ & $\$ 0$ & $\$ 225,000$ \\
\hline Package/fix contamination Metal \& lead & $\$ 0$ & $\$ 0$ & $\$ 0$ & $\$ 150,000$ \\
\hline Transport Metal and Lead & $\$ 0$ & $\$ 0$ & $\$ 0$ & $\$ 90,000$ \\
\hline Process Lead Macroencapsulate & $\$ 0$ & $\$ 0$ & $\$ 0$ & $\$ 820,000$ \\
\hline Fill Void spaces & $\$ 0$ & $\$ 0$ & $\$ 0$ & $\$ 450,000$ \\
\hline WAC Validation Package & $\$ 0$ & $\$ 0$ & $\$ 0$ & $\$ 300,000$ \\
\hline Disposal LLW & $\$ 11,154$ & $\$ 20,813$ & $\$ 29,268$ & $\$ 1,288,085$ \\
\hline Disposal MW & $\$ 0$ & $\$ 0$ & $\$ 0$ & $\$ 604,853$ \\
\hline Sub Total Costs & $\$ 103,309$ & $\$ 486,626$ & $\$ 172,536$ & $\$ 6,534,119$ \\
\hline Project Plan as \% of ST & $\$ 30,993$ & $\$ 145,988$ & $\$ 51,761$ & $\$ 1,960,236$ \\
\hline Project Management as \% of ST & $\$ 10,331$ & $\$ 48,663$ & $\$ 17,254$ & $\$ 653,412$ \\
\hline Total & $\$ 155,787$ & $\$ 702,089$ & $\$ 270,818$ & $\$ 9,209,002$ \\
\hline Total Cost/Ca:r & $\$ 155,787$ & $\$ 14,042$ & $\$ 135,409$ & 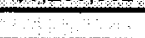 \\
\hline
\end{tabular}

Cost to Build Facility:

$\$ 1,530,000$ 


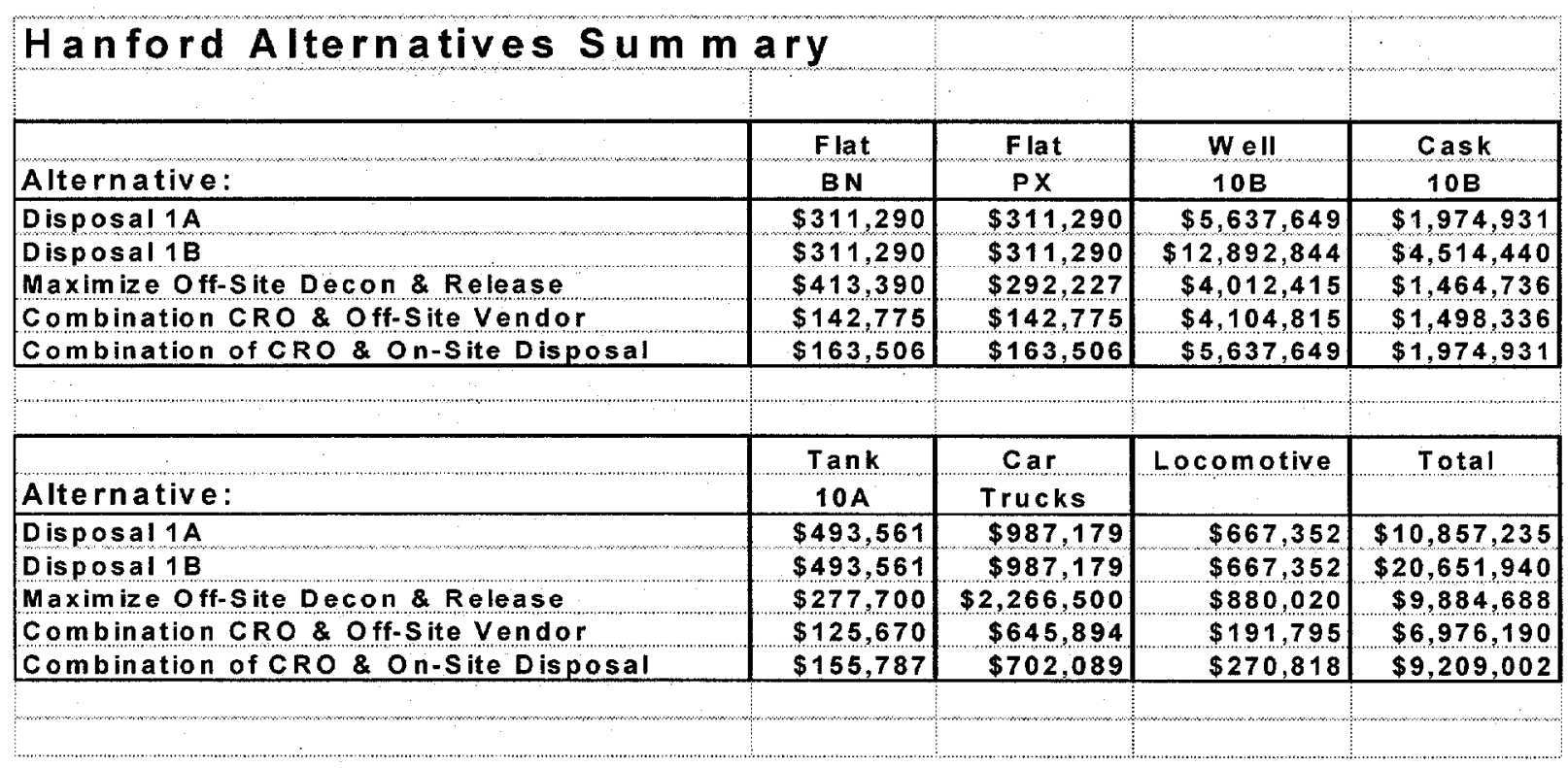





\title{
Appendix C
}

\author{
Uncertainty Analysis
}


$=$ 
Crystal Ball Report

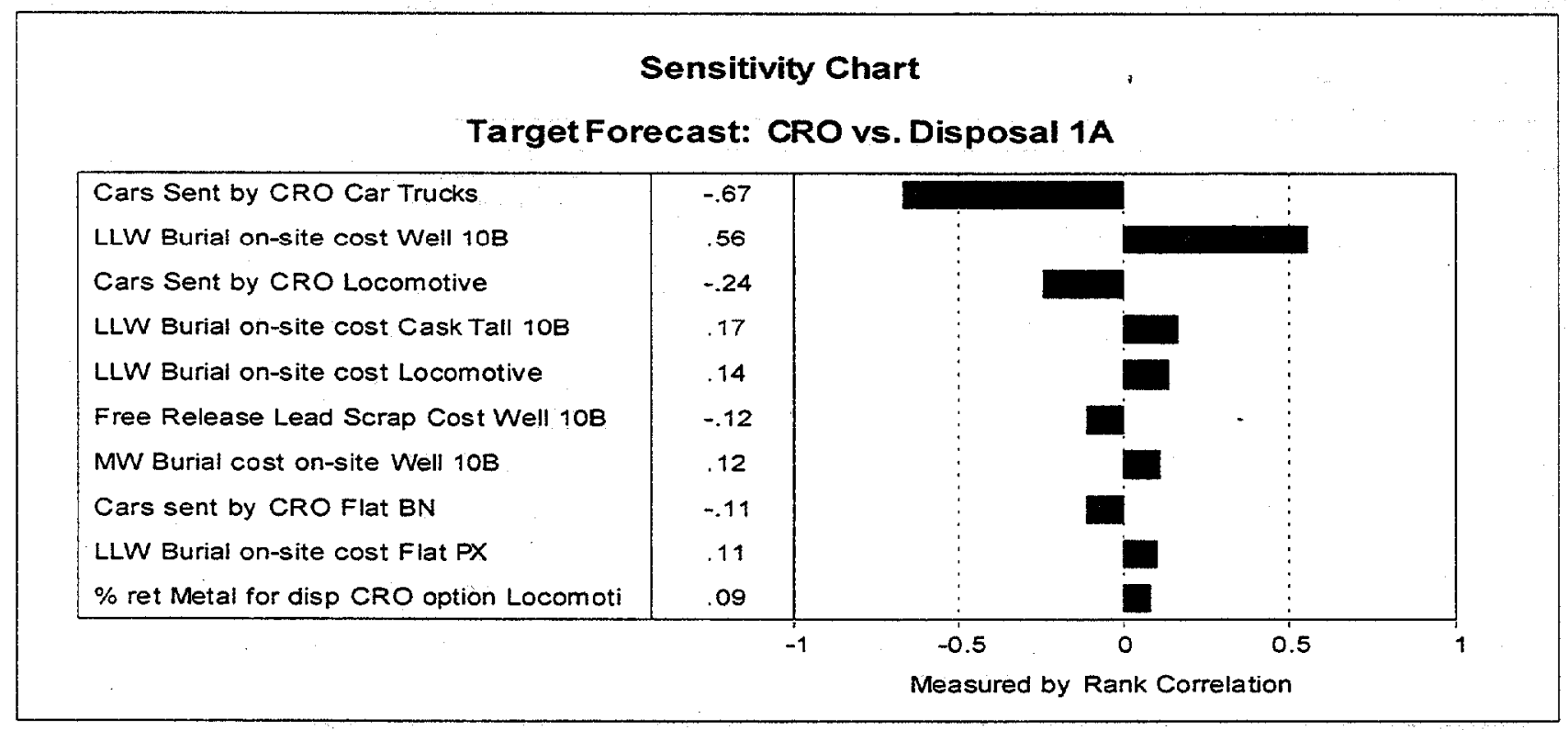


Summary:

Display Range is from $\$ 10,500,000$ to $\$ 14,000,000$

Entire Range is from $\$ 10,748,679$ to $\$ 13,544,301$

After 5,000 Trials, the Std. Error of the Mean is $\$ 7,257$

Statistics:

Trials

Value

Mean

5000

Median

$\$ 12,225,612$

Mode

Standard Deviation

$\$ 12,224,209$

Variance

$\$ 11,175,866$

$\$ 513,173$

Skewness

$3 \mathrm{E}+11$

0.01

Kurtosis

2.36

Coeff. of Variability

0.04

Range Minimum

$\$ 10,748,679$

Range Maximum

$\$ 13,544,301$

Range Width

$\$ 2,795,621$

Mean Std. Error

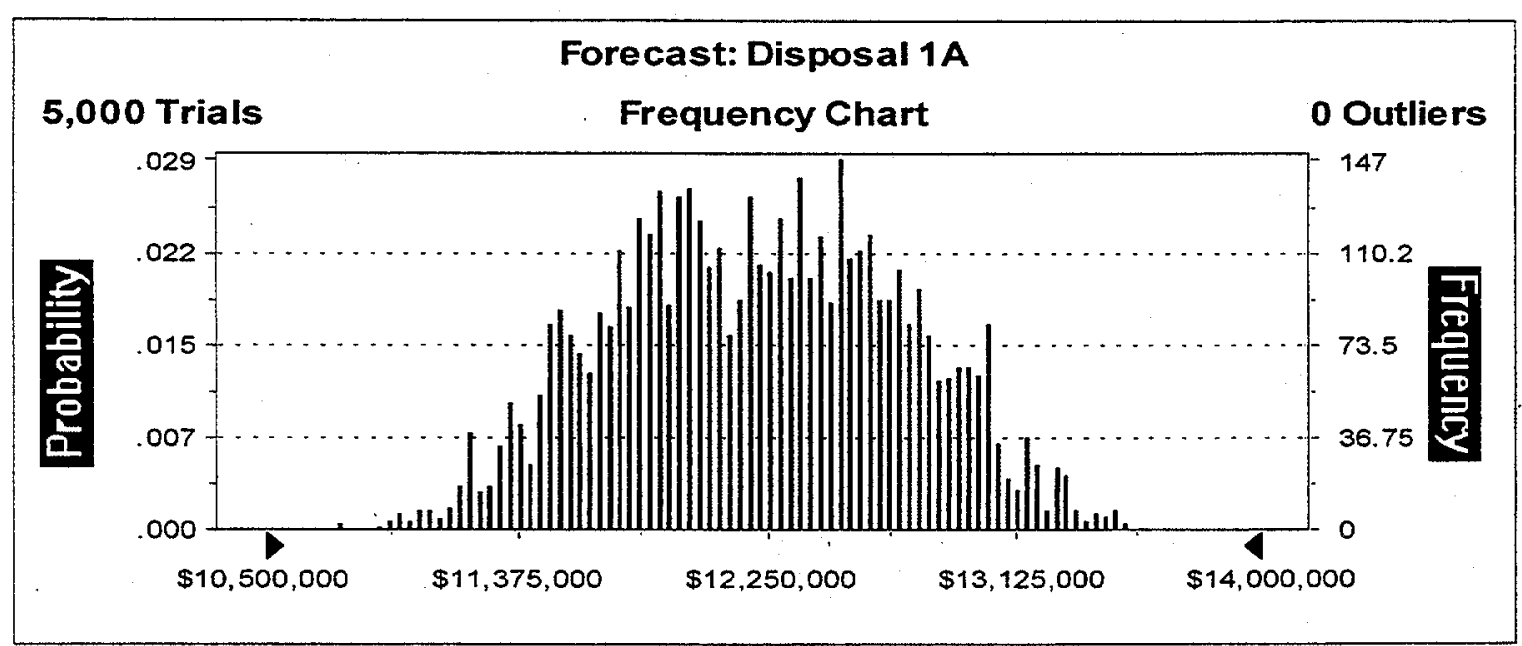


Forecast: Disposal 1A (cont'd)

Cell: E14

Percentiles:

\begin{tabular}{rr} 
Percentile & Value \\
\hline $0 \%$ & $\$ 10,748,679$ \\
$10 \%$ & $\$ 11,546,254$ \\
$20 \%$ & $\$ 11,757,392$ \\
$30 \%$ & $\$ 11,913,867$ \\
$40 \%$ & $\$ 12,055,782$ \\
$50 \%$ & $\$ 12,224,209$ \\
$60 \%$ & $\$ 12,377,854$ \\
$70 \%$ & $\$ 12,531,953$ \\
$80 \%$ & $\$ 12,699,658$ \\
$90 \%$ & $\$ 12,916,515$ \\
$100 \%$ & $\$ 13,544,301$
\end{tabular}

End of Forecast 
Summary:

Display Range is from $\$ 13,000,000$ to $\$ 22,000,000$

Entire Range is from $\$ 13,624,261$ to $\$ 21,558,511$

After 5,000 Trials, the Std. Error of the Mean is $\$ 23,838$

Statistics:

Trials

Value

Mean

5000

Median

$\$ 17,632,163$

Mode

Standard Deviation

$\$ 17,629,050$

Variance

$\$ 14,176,191$

Skewness

$\$ 1,685,613$

$3 E+12$

0.01

Kurtosis

2.10

Coeff. of Variability

0.10

Range Minimum

$\$ 13,624,261$

Range Maximum

$\$ 21,558,511$

Range Width

$\$ 7,934,250$

Mean Std. Error

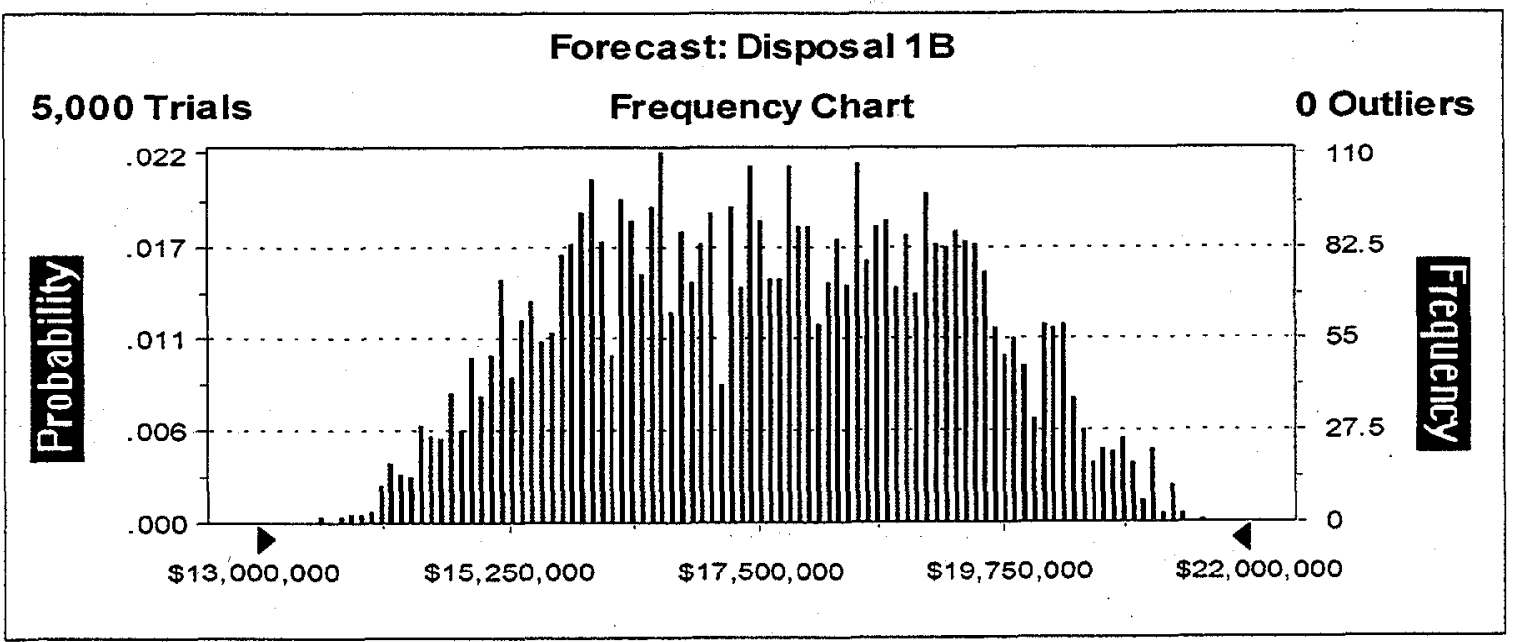


Forecast: Disposal 1B (cont'd)

Percentiles:

$\begin{array}{rr}\text { Percentile } & \frac{\text { Value }}{20 \%} \\ 10 \% & \$ 13,624,261 \\ 20 \% & \$ 15,391,962 \\ 30 \% & \$ 16,003,060 \\ 40 \% & \$ 16,555,793 \\ 50 \% & \$ 17,070,135 \\ 60 \% & \$ 17,629,050 \\ 70 \% & \$ 18,184,203 \\ 80 \% & \$ 18,702,226 \\ 90 \% & \$ 19,260,299 \\ 100 \% & \$ 19,871,086 \\ & \$ 21,558,511\end{array}$

End of Forecast 
Summary:

Certainty Level is $80.00 \%$

Certainty Range is from $\$ 9,639,974$ to $\$ 10,037,877$

Display Range is from $\$ 9,400,000$ to $\$ 10,300,000$

Entire Range is from $\$ 9,252,561$ to $\$ 10,415,380$

After 5,000 Trials, the Std. Error of the Mean is $\$ 2,185$

Statistics:

Trials

$\underline{\text { Value }}$

Mean

5000

Median

$\$ 9,842,223$

Mode

$\$ 9,843,311$

Standard Deviation

$\$ 154,507$

Variance

$\$ 23,872,379,390$

Skewness

$-0.04$

Kurtosis

$2: 97$

Coeff. of Variability

0.02

Range Minimum

$\$ 9,252,561$

Range Maximum

$\$ 10,415,380$

Range Width

$\$ 1,162,819$

Mean Std. Error

$\$ 2,185.06$

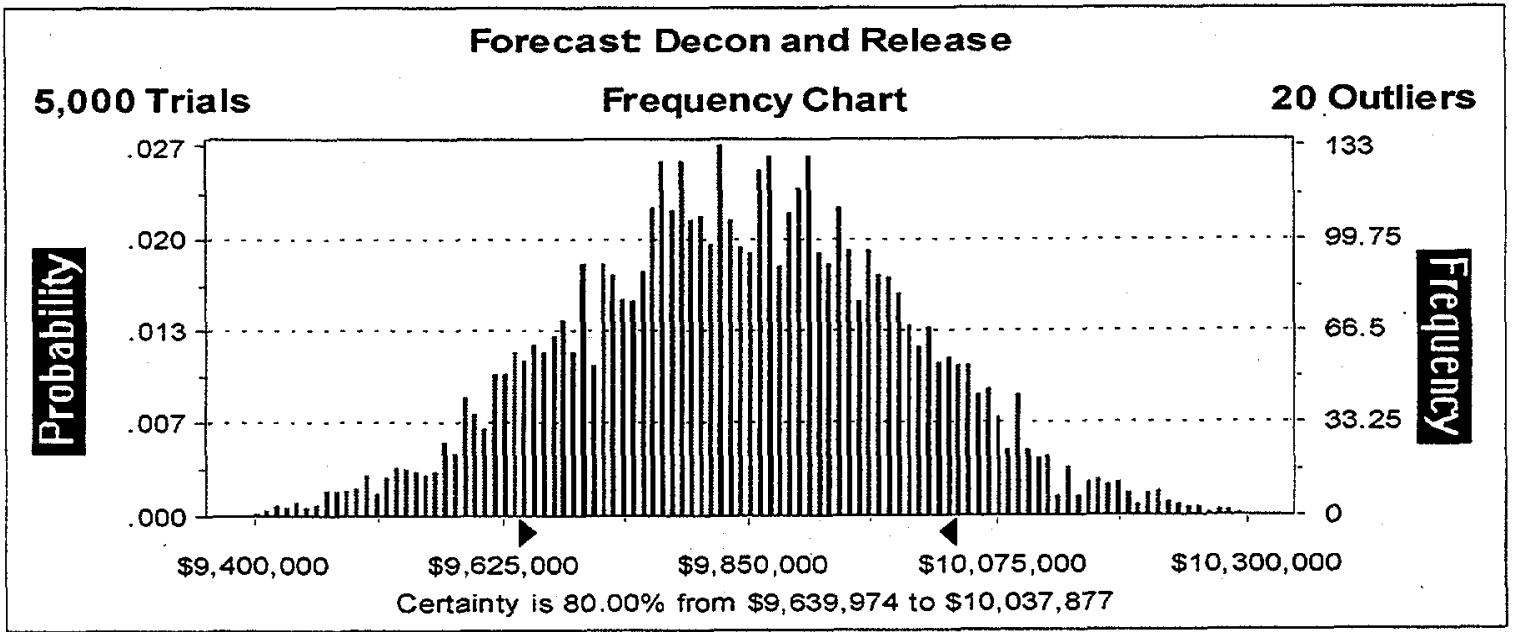


Forecast: Decon and Release (cont'd)

Percentiles:

\begin{tabular}{r} 
Percentile \\
\hline $0 \%$ \\
$10 \%$ \\
$20 \%$ \\
$30 \%$ \\
$40 \%$ \\
$50 \%$ \\
$60 \%$ \\
$70 \%$ \\
$80 \%$ \\
$90 \%$ \\
$100 \%$
\end{tabular}
Value
$\$ 9,252,561$
$\$ 9,641,289$
$\$ 9,709,740$
$\$ 9,764,805$
$\$ 9,802,599$
$\$ 9,843,311$
$\$ 9,884,790$
$\$ 9,924,708$
$\$ 9,973,650$
$\$ 10,039,263$
$\$ 10,415,380$

End of Forecast 
Summary:

Certainty Level is $80.00 \%$

Certainty Range is from $\$ 7,873,993$ to $\$ 9,409,361$

Display Range is from $\$ 7,000,000$ to $\$ 10,500,000$

Entire Range is from $\$ 7,113,804$ to $\$ 10,292,491$

After 5,000 Trials, the Std. Error of the Mean is $\$ 8,211$

Statistics:

Trials

$\underline{\text { Value }}$

Mean

5000

Median

$\$ 8,637,358$

Mode

$\$ 8,635,679$

Standard Deviation

Variance

$\$ 580,572$

$3 \mathrm{E}+11$

0.01

Skewness

$2: 29$

Kurtosis

0.07

Coeff. of Variability

$\$ 7,113,804$

Range Minimum

$\$ 10,292,491$

Range Maximum

$\$ 3,178,687$

Mean Std. Error

$\$ 8,210.53$

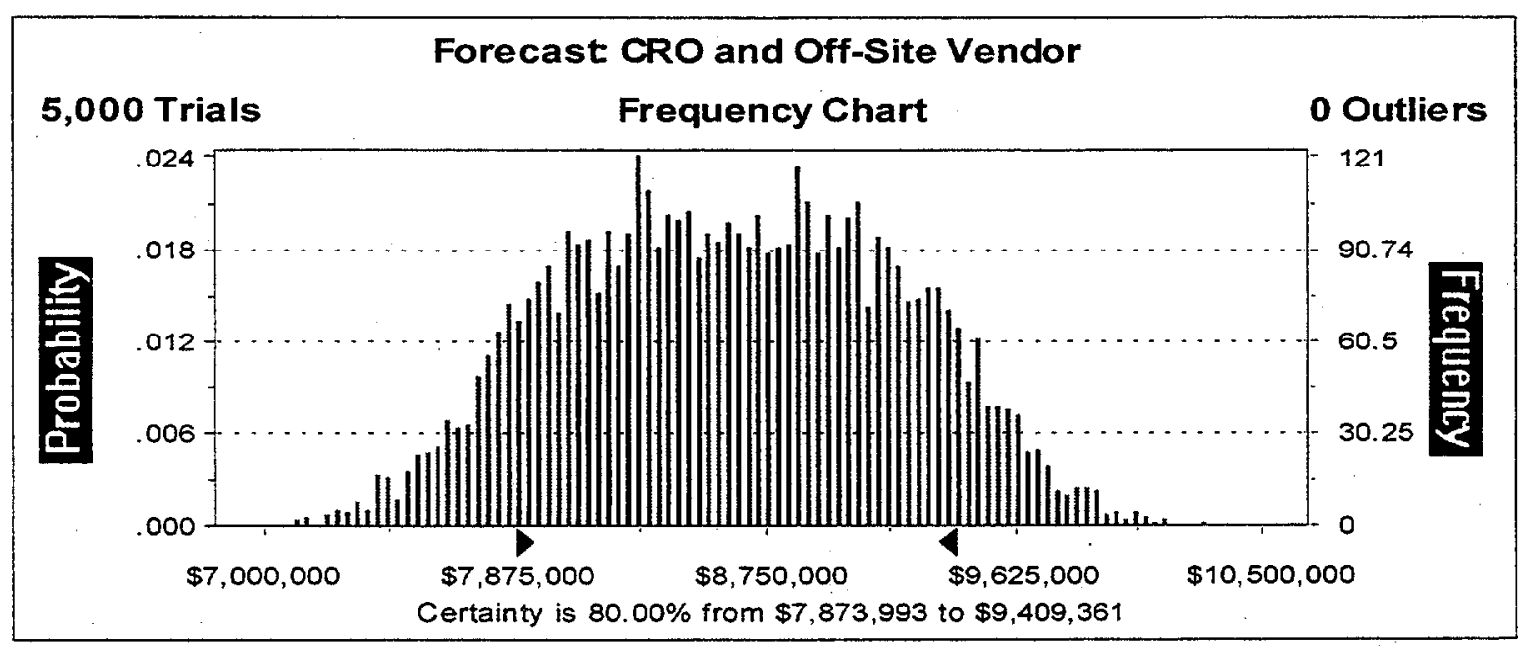


Forecast: CRO and Off-Site Vendor (cont'd)

Percentiles:

\begin{tabular}{rr} 
Percentile & Value \\
\hline $0 \%$ & $\$ 7,113,804$ \\
$10 \%$ & $\$ 7,870,000$ \\
$20 \%$ & $\$ 8,091,438$ \\
$30 \%$ & $\$ 8,286,536$ \\
$40 \%$ & $\$ 8,454,423$ \\
$50 \%$ & $\$ 8,635,679$ \\
$60 \%$ & $\$ 8,820,714$ \\
$70 \%$ & $\$ 8,993,751$ \\
$80 \%$ & $\$ 9,177,688$ \\
$90 \%$ & $\$ 9,402,215$ \\
$100 \%$ & $\$ 10,292,491$
\end{tabular}

End of Forecast 
Summary:

Certainty Level is $80.04 \%$

Certainty Range is from $\$ 10,739,041$ to $\$ 12,632,556$

Display Range is from $\$ 9,500,000$ to $\$ 14,000,000$

Entire Range is from $\$ 9,386,045$ to $\$ 13,891,280$

After 5,000 Trials, the Std. Error of the Mean is $\$ 10,203$

Statistics:

Trials

Value

5000

Mean

Median

$\$ 11,639,508$

Mode

Standard Deviation

Variance

Skewness

$\$ 11,625,017$

$\$ 9,501,745$

$\$ 721,476$

$5 E+11$

0.09

Kurtosis

$2: 78$

0.06

Range Minimum

$\$ 9,386,045$

Range Maximum

$\$ 13,891,280$

Range Width

$\$ 4,505,235$

Mean Std. Error

$\$ 10,203.21$

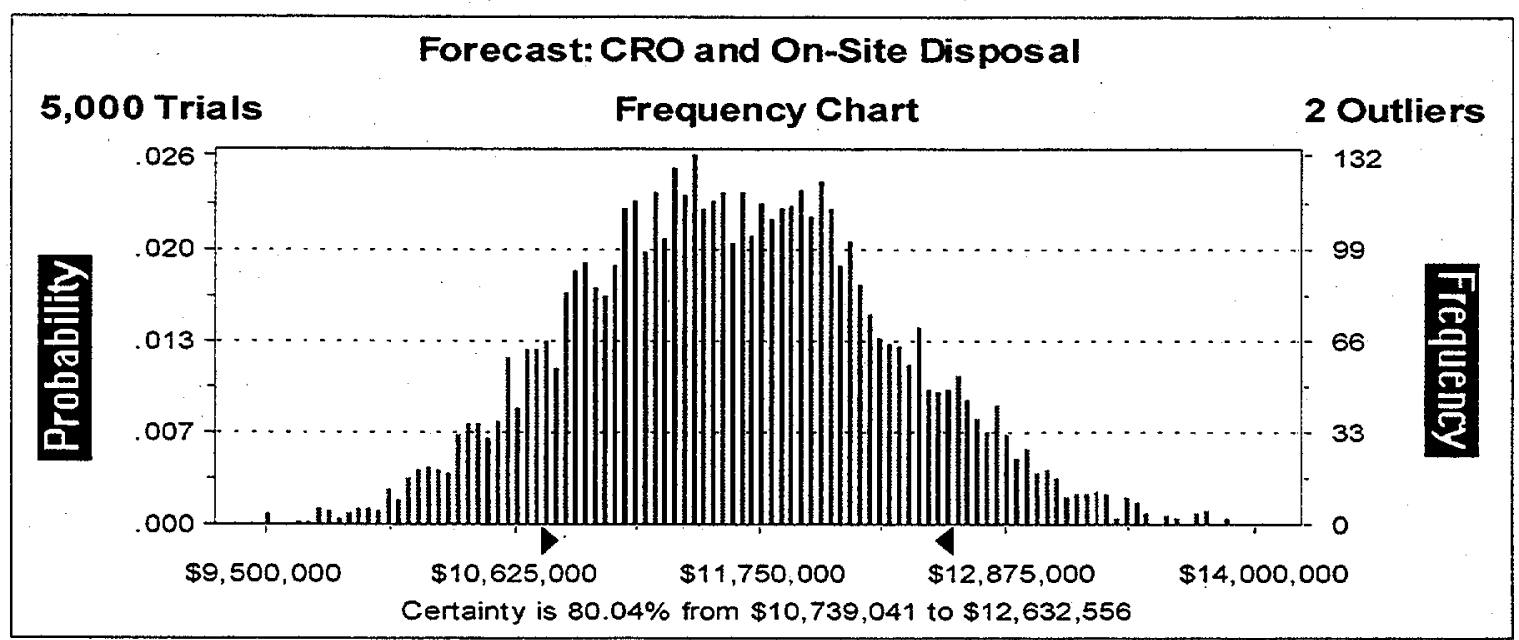


Forecast: CRO and On-Site Disposal (cont'd)

Cell: E18

Percentiles:

\begin{tabular}{rr} 
Percentile & $\frac{\text { Value }}{}$ \\
\hline $0 \%$ & $\$ 9,386,045$ \\
$10 \%$ & $\$ 10,716,558$ \\
$20 \%$ & $\$ 11,011,460$ \\
$30 \%$ & $\$ 11,240,606$ \\
$40 \%$ & $\$ 11,431,521$ \\
$50 \%$ & $\$ 11,625,017$ \\
$60 \%$ & $\$ 11,825,897$ \\
$70 \%$ & $\$ 12,024,447$ \\
$80 \%$ & $\$ 12,240,808$ \\
$90 \%$ & $\$ 12,600,030$ \\
$100 \%$ & $\$ 13,891,280$
\end{tabular}

End of Forecast 
Summary:

Certainty Level is $80.00 \%$

Certainty Range is from $\$ 5,540,464$ to $\$ 10,049,505$

Display Range is from $\$ 3,000,000$ to $\$ 12,000,000$

Entire Range is from $\$ 3,602,129$ to $\$ 11,783,116$

After 5,000 Trials, the Std. Error of the Mean is $\$ 23,938$

Statistics:

Trials

Value

Mean

5000

Median

$\$ 7,789,940$

Mode

Standard Deviation

$\$ 7,785,584$

Variance

$\$ 1,692,656$

Skewness

$3 E+12$

0.01

$2: 12$

Kurtosis

0.22

Coeff. of Variability

0.22

Range Minimum

Range Maximum

Range Width

$\$ 3,602,129$

$\$ 11,783,116$

$\$ 8,180,988$

Mean Std. Error

\section{Forecast: Savings from Recycle over Disposal 1B}

5,000 Trials Frequency Chart

0 Outliers
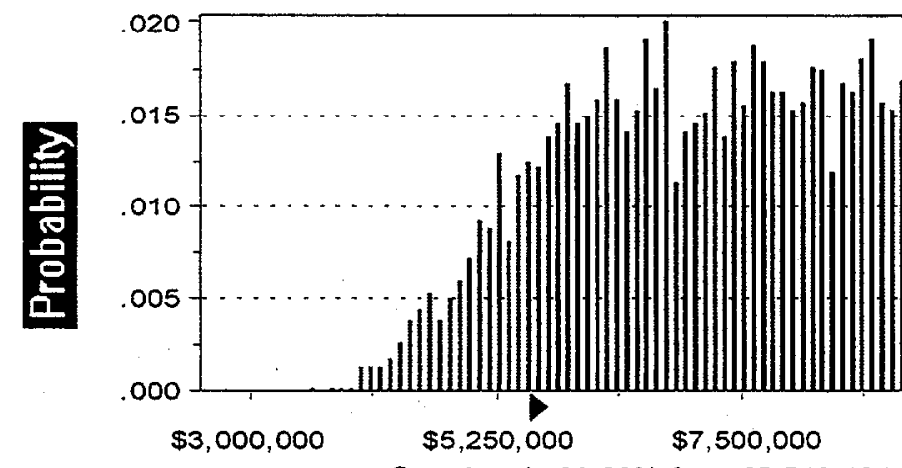

Certainty is $80.00 \%$ from $\$ 5,540,464$ to $\$ 10,049,505$ 
Forecast: Savings from Recycle over Disposal 1B (cont'd)

Cell: E20

Percentiles:

\begin{tabular}{r} 
Percentile \\
\hline $0 \%$ \\
$10 \%$ \\
$20 \%$ \\
$30 \%$ \\
$40 \%$ \\
$50 \%$ \\
$60 \%$ \\
$70 \%$ \\
$80 \%$ \\
$90 \%$ \\
$100 \%$
\end{tabular}

Value
$\$ 3,602,129$
$\$ 5,536,617$
$\$ 6,152,892$
$\$ 6,689,899$
$\$ 7,261,518$
$\$ 7,785,584$
$\$ 8,332,944$
$\$ 8,862,217$
$\$ 9,422,807$
$\$ 10,048,534$
$\$ 11,783,116$

End of Forecast 
Summary:

Certainty Level is $79.82 \%$

Certainty Range is from $\$ 1,699,905$ to $\$ 3,103,669$

Display Range is from $\$ 500,000$ to $\$ 4,000,000$

Entire Range is from $\$ 738,607$ to $\$ 3,897,934$

After 5,000 Trials, the Std. Error of the Mean is $\$ 7,601$

Statistics:

Trials

Value

Mean

5000

Median

$\$ 2,383,389$

Mode

$\$ 2,374,367$

Standard Deviation

$\$ 537,500$

Variance

$3 E+11$

Skewness

0.01

Kurtosis

2: 46

Coeff. of Variability

0.23

Range Minimum

$\$ 738,607$

Range Maximum

$\$ 3,897,934$

Range Width

$\$ 3,159,327$

Mean Std. Error

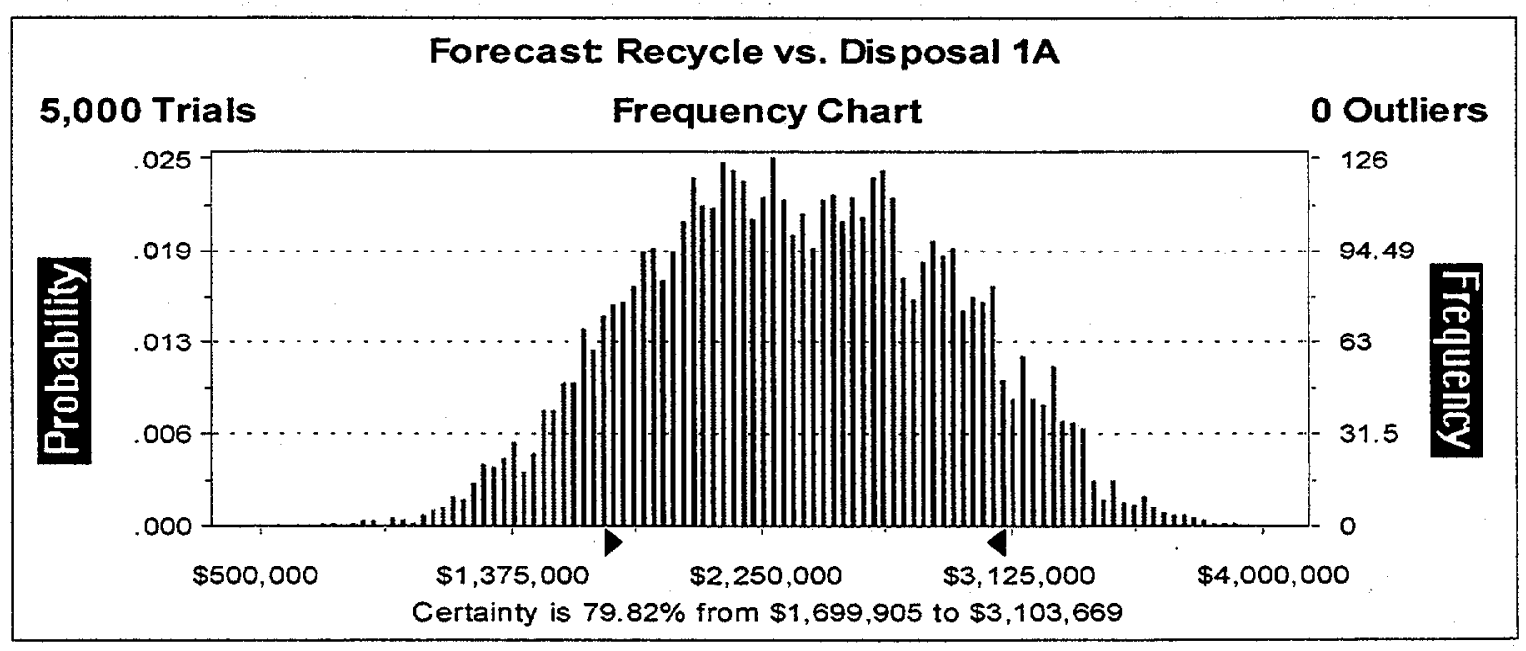


Forecast: Recycle vs. Disposal 1A (cont'd)

Percentiles:

\begin{tabular}{r} 
Percentile \\
\hline $0 \%$ \\
$10 \%$ \\
$20 \%$ \\
$30 \%$ \\
$40 \%$ \\
$50 \%$ \\
$60 \%$ \\
$70 \%$ \\
$80 \%$ \\
$90 \%$ \\
$100 \%$
\end{tabular}
Value
$\$ 738,607$
$\$ 1,685,266$
$\$ 1,897,261$
$\$ 2,069,440$
$\$ 2,218,079$
$\$ 2,374,367$
$\$ 2,536,448$
$\$ 2,693,402$
$\$ 2,878,382$
$\$ 3,085,675$
$\$ 3,897,934$

End of Forecast 
Summary:

Certainty Level is $80.06 \%$

Certainty Range is from $\$ 2,577,099$ to $\$ 4,600,156$

Display Range is from $\$ 1,500,000$ to $\$ 6,000,000$

Entire Range is from $\$ 1,181,901$ to $\$ 6,048,564$

After 5,000 Trials, the Std. Error of the Mean is $\$ 10,942$

Statistics:

Trials

Value

Mean

5000

Median

$\$ 3,588,255$

Mode

$\$ 3,593,380$

Standard Deviation

Variance

$\$ 773,746$

$6 \mathrm{E}+11$

Skewness

$-0.02$

Kurtosis

$2: 74$

Coeff. of Variability

0.22

Range Minimum

$\$ 1,181,901$

Range Maximum

$\$ 6,048,564$

Range Width

$\$ 4,866,663$

Mean Std. Error

$\$ 10,942.43$

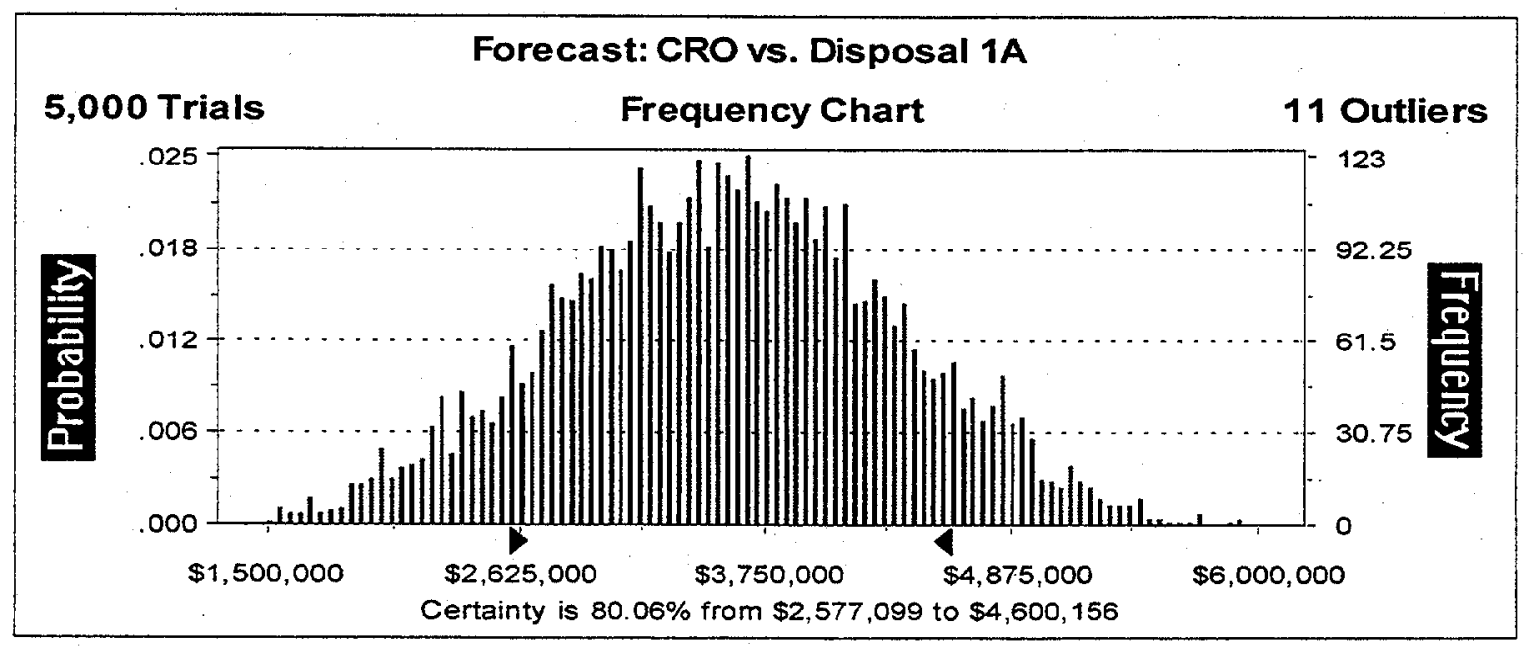


Forecast: CRO vs. Disposal 1A (cont'd)

Percentiles:

$\begin{array}{rr}\text { Percentile } & \frac{\text { Value }}{20 \%} \\ 10 \% & \$ 1,181,901 \\ 20 \% & \$ 2,585,707 \\ 30 \% & \$ 2,925,260 \\ 40 \% & \$ 3,171,426 \\ 50 \% & \$ 3,391,595 \\ 60 \% & \$ 3,593,380 \\ 70 \% & \$ 3,792,460 \\ 80 \% & \$ 4,007,181 \\ 90 \% & \$ 4,254,095 \\ 100 \% & \$ 4,608,835 \\ & \$ 6,048,564\end{array}$

End of Forecast 
Summary:

Certainty Level is $80.00 \%$

Certainty Range is from $\$ 6,633,518$ to $\$ 11,389,345$

Display Range is from $\$ 4,000,000$ to $\$ 14,000,000$

Entire Range is from $\$ 4,148,638$ to $\$ 13,869,389$

After 5,000 Trials, the Std. Error of the Mean is $\$ 25,306$

Statistics:

Trials

Mean

Value

Median

5000

Mode

Standard Deviation

Variance

Skewness

$\$ 8,994,806$

$\$ 8,984,347$

$\$ 1,789,404$

$3 E+12$

0.01

Kurtosis

2.28

Coeff. of Variability

0.20

Range Minimum

Range Maximum

$\$ 4,148,638$

Range Width

$\$ 13,869,389$

$\$ 9,720,752$

Mean Std. Error

$\$ 25,306.00$

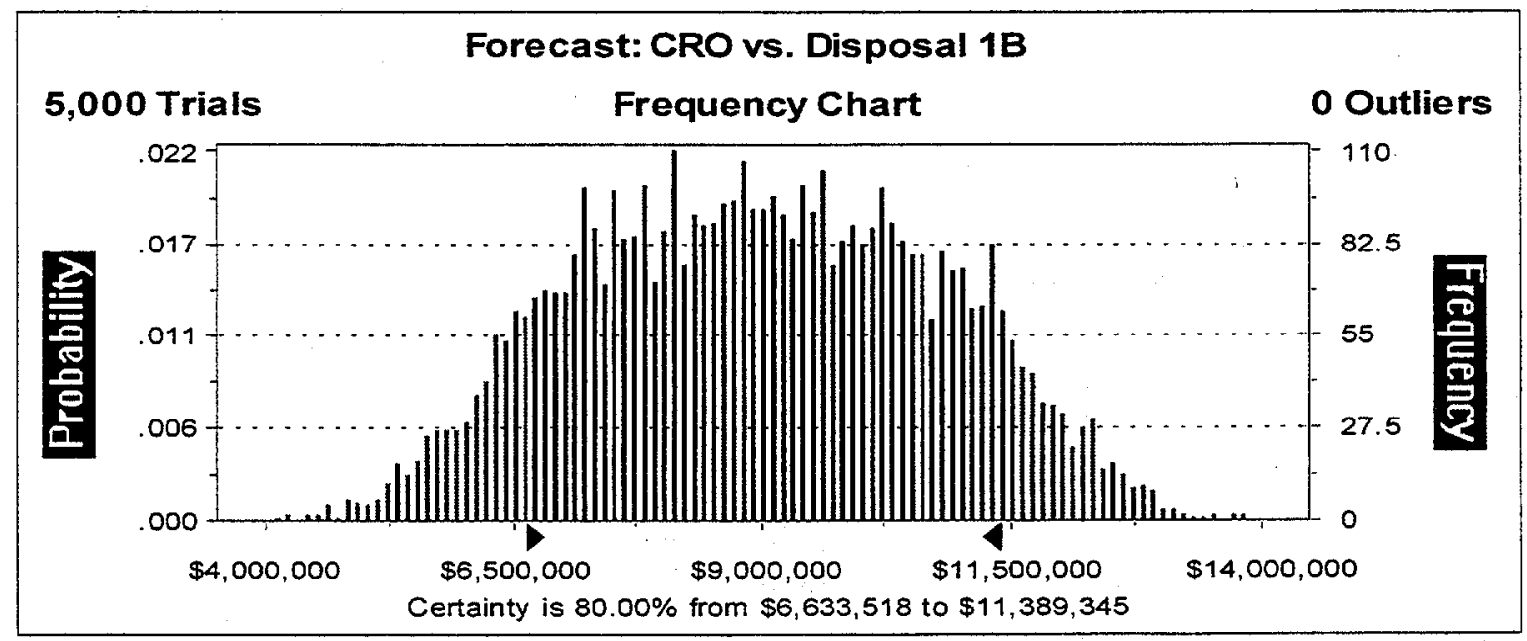


Forecast: CRO vs. Disposal 1B (cont'd)

Percentiles:

\begin{tabular}{r} 
Percentile \\
\hline $0 \%$ \\
$10 \%$ \\
$20 \%$ \\
$30 \%$ \\
$40 \%$ \\
$50 \%$ \\
$60 \%$ \\
$70 \%$ \\
$80 \%$ \\
$90 \%$ \\
$100 \%$
\end{tabular}

$\frac{\text { Value }}{}$
$\$ 4,148,638$
$\$ 6,618,426$
$\$ 7,308,837$
$\$ 7,884,375$
$\$ 8,450,818$
$\$ 8,984,347$
$\$ 9,530,088$
$\$ 10,090,269$
$\$ 10,668,123$
$\$ 11,375,018$
$\$ 13,869,389$

End of Forecast 


\section{Assumptions}

Assumption: LLW Burial on-site cost Flat BN

Cell: $\mathbf{B 2 5}$

Uniform distribution with parameters:

Minimum

$\$ 15.00$

Maximum

$\$ 35.00$

Mean value in simulation was $\$ 24.96$

Assumption: LLW Burial on-site cost Flat PX

Cell: $\mathbf{C 2 5}$

Uniform distribution with parameters:

Minimum

$\$ 15.00$

Maximum

$\$ 35.00$

Mean value in simulation was $\$ 24.91$

Assumption: LLW Burial on-site cost Well 10B

Cell: D25

Uniform distribution with parameters: Minimum

Maximum

$\$ 15.00$

$\$ 35.00$

Mean value in simulation was $\$ 24.83$
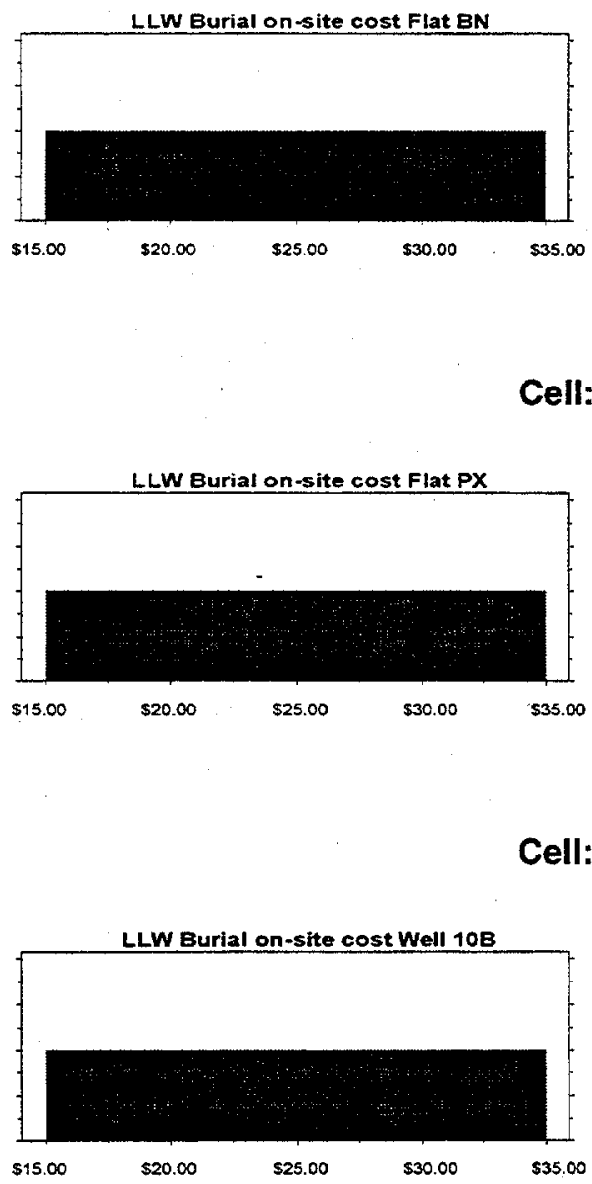

Assumption: LLW Burial on-site cost Cask Tall 10B

Cell: E25

Uniform distribution with parameters:

Minimum

$\$ 15.00$

Maximum

$\$ 35.00$

Mean value in simulation was $\$ 24.92$

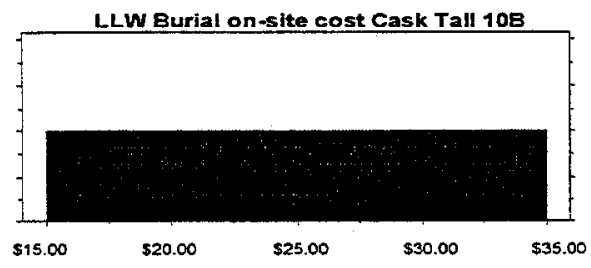


Uniform distribution with parameters: Minimum

$\$ 15.00$

Maximum

$\$ 35.00$

Mean value in simulation was $\$ 24.92$

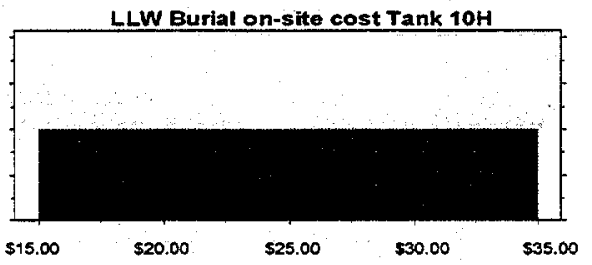

Cell: G25

$\$ 15.00$

$\$ 35.00$

Maximum

Mean value in simulation was $\$ 24.91$

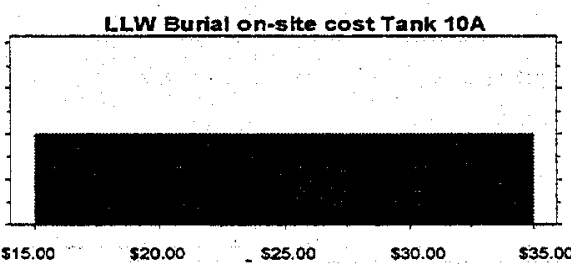

Cell: $\mathrm{H} 25$ $\$ 35.00$

Minimum

Maximum

$\$ 35.00$

Mean value in simulation was $\$ 24.87$

Assumption: LLW Burial on-site cost Locomotive

Cell: 125

Uniform distribution with parameters:

Minimum

Maximum

$\$ 15.00$

$\$ 35.00$

Mean value in simulation was $\$ 24.96$
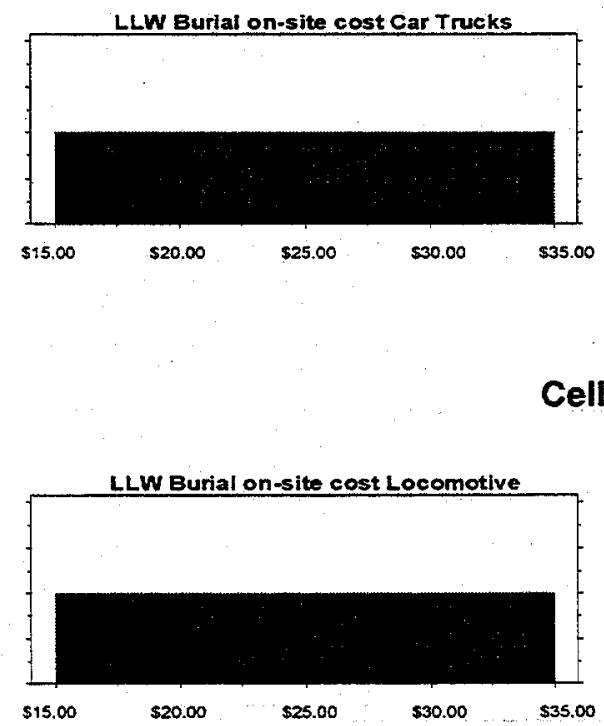
Uniform distribution with parameters: Minimum

Maximum

Mean value in simulation was $\$ 93.88$

Assumption: MW Burial cost on-site Flat PX

Uniform distribution with parameters: Minimum Maximum $\$ 128.00$

Mean value in simulation was $\$ 93.78$

Assumption: MW Burial cost on-site Well 10B

Uniform distribution with parameters: Minimum

Maximum

$\$ 128.00$

Mean value in simulation was $\$ 93.82$

Assumption: MW Burial cost on-site Cask 10B

Uniform distribution with parameters: Minimum

Maximum

$\$ 128.00$

Mean value in simulation was $\$ 93.79$

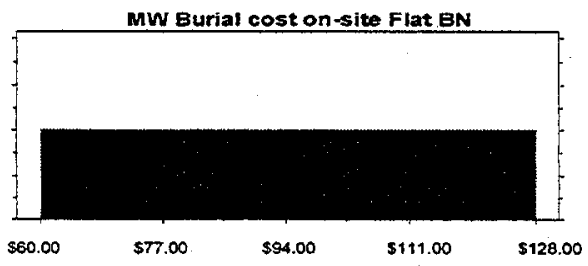

Cell: $\mathbf{C 2 6}$

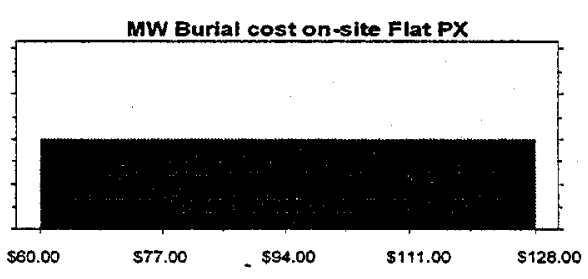

Cell: D26

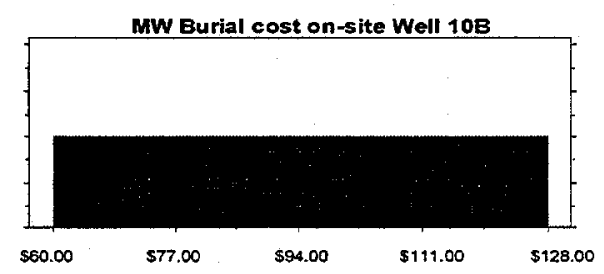

Cell: E26

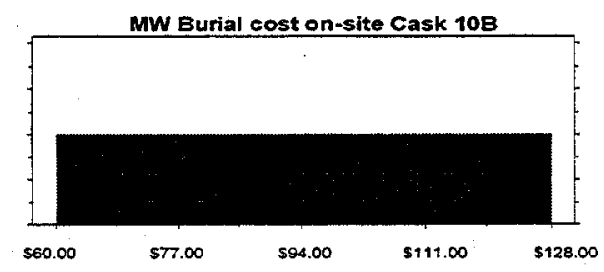


Uniform distribution with parameters: Minimum

Maximum

$\$ 128.00$

Mean value in simulation was $\$ 93.61$

Assumption: MW Burial cost on-site Tank 10A

Uniform distribution with parameters: Minimum

Maximum

Mean value in simulation was $\$ 93.69$

Assumption: MW Burial cost on-site Car Trucks

Uniform distribution with parameters: Minimum

$\$ 60.00$

Maximum

$\$ 128.00$

Mean value in simulation was $\$ 93.73$

Assumption: MW Burial cost on-site Locomotive

Uniform distribution with parameters: Minimum $\$ 60.00$ Maximum $\$ 128.00$

Mean value in simulation was $\$ 93.66$

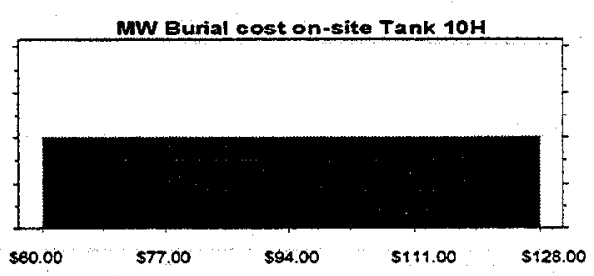

Cell: G26

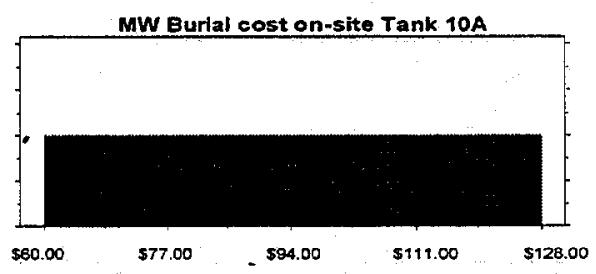

Cell: H26

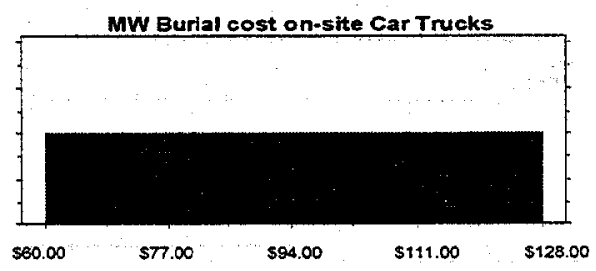

Cell: 126

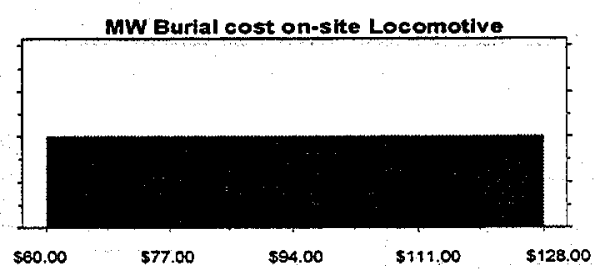


Normal distribution with parameters:

Mean

Standard Dev. $\$ 0.09$

Selected range is from - Infinity to + Infinity Mean value in simulation was $\$ 0.90$

\section{Assumption: Free Rel Metal Scrap Cost Flat PX}

Normal distribution with parameters:

Mean

Standard Dev.

$\$ 0.09$

Selected range is from -Infinity to + Infinity Mean value in simulation was $\$ 0.90$

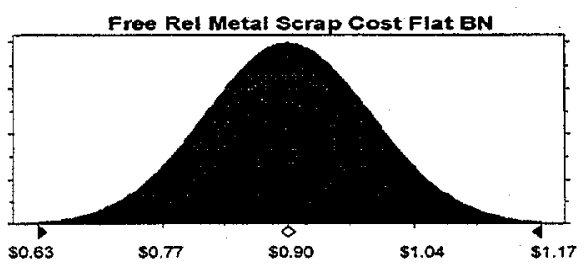

Cell: $\mathbf{C 2 7}$

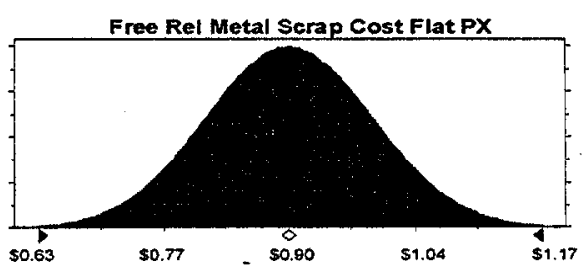

Cell: D27

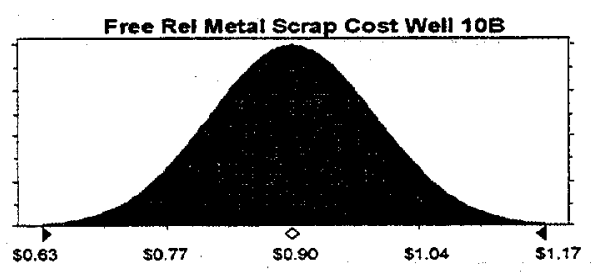

Selected range is from - Infinity to +Infinity

Mean value in simulation was $\$ 0.90$

\section{Assumption: Free Rel Metal Scrap Cost Cask 10B}

Cell: E27

Normal distribution with parameters:

Mean

$\$ 0.90$

Standard Dev.

$\$ 0.09$

Selected range is from -Infinity to + Infinity Mean value in simulation was $\$ 0.90$

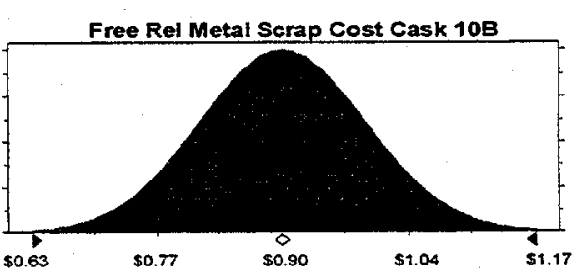


Normal distribution with parameters:

$$
\text { Mean }
$$

Standard Dev.

Selected range is from - Infinity to + Infinity Mean value in simulation was $\$ 0.90$

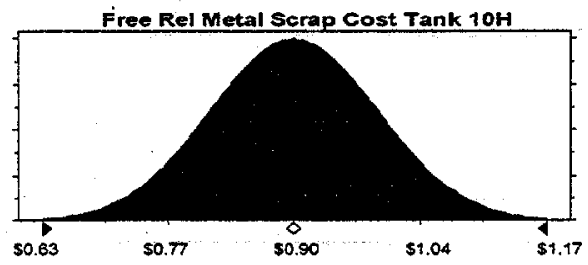

Cell: G27

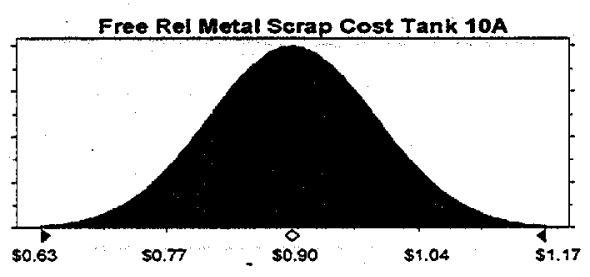

Selected range is from - Infinity to
Mean value in simulation was $\$ 0.90$

\section{Assumption: Free Rel Metal Scrap Cost Car Trucks}

Cell: $\mathrm{H} 27$

Normal distribution with parameters:

Mean

Standard Dev.

Selected range is from -Infinity to + Infinity Mean value in simulation was $\$ 0.90$

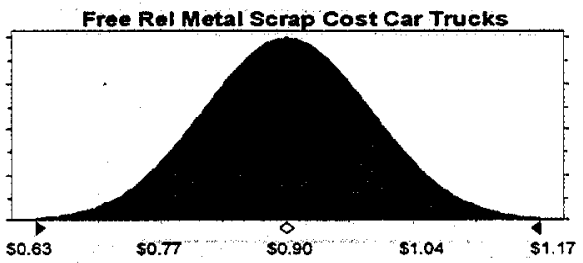

\section{Assumption: Free Rel Metal Scrap Cost Locomotive}

Normal distribution with parameters:

Mean

Standard Dev.

$\$ 0.09$

Selected range is from - Infinity to + Infinity Mean value in simulation was $\$ 0.90$

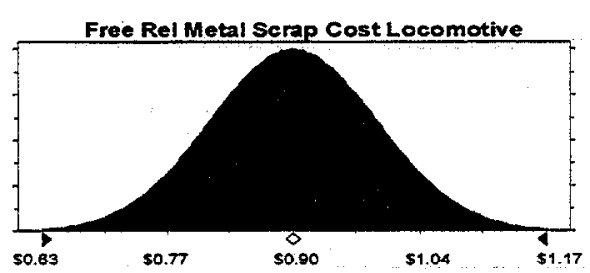


Normal distribution with parameters:

Mean

Standard Dev.

Selected range is from - Infinity to + Infinity Mean value in simulation was $\$ 0.84$

\section{Assumption: Free Release Lead Scrap Cost Flat PX}

Normal distribution with parameters:

Mean

Standard Dev.

Selected range is from -Infinity to + Infinity Mean value in simulation was $\$ 0.84$

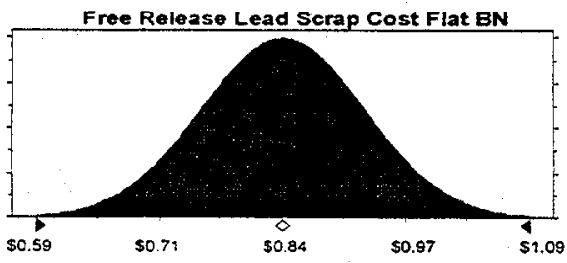

Cell: $\mathbf{C 2 8}$

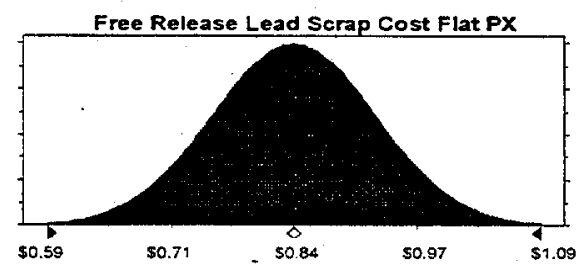

Cell: D28

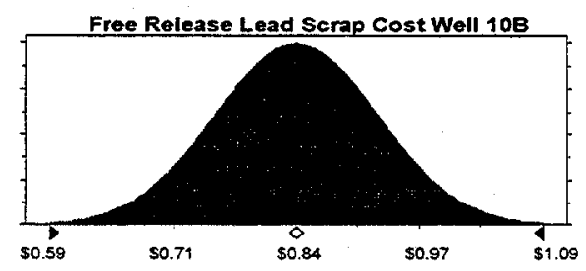

Selected range is from -Infinity to + Infinity Mean value in simulation was $\$ 0.84$

\section{Assumption: Free Release Lead Scrap Cost Cask 10B}

Cell: E28

Normal distribution with parameters:

Mean

Standard Dev.

$\$ 0.84$

$\$ 0.08$

Selected range is from -Infinity to + Infinity Mean value in simulation was $\$ 0.84$

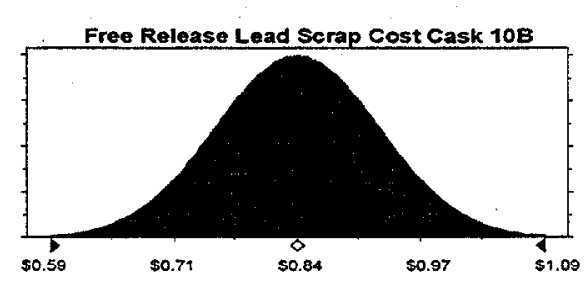


Normal distribution with parameters:

$$
\begin{aligned}
& \text { Mean } \\
& \text { Standard Dev. }
\end{aligned}
$$

Selected range is from -Infinity to + Infinity

Mean value in simulation was $\$ 0.84$

Assumption: Free Release Lead Scrap Cost Tank 10A

Normal distribution with parameters:

Mean

Standard Dev.

$\$ 0.08$

Selected range is from -Infinity to + Infinity

Mean value in simulation was $\$ 0.84$

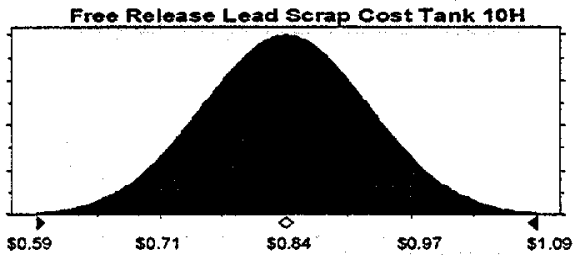

Cell: G28

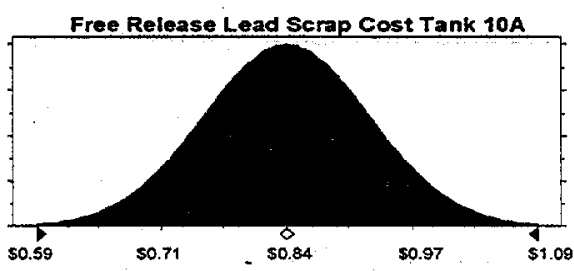

Cell: $\mathrm{H} 28$

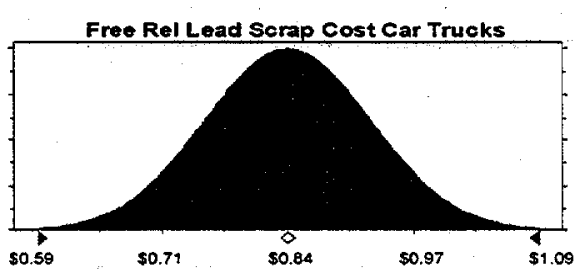

Cell: 128

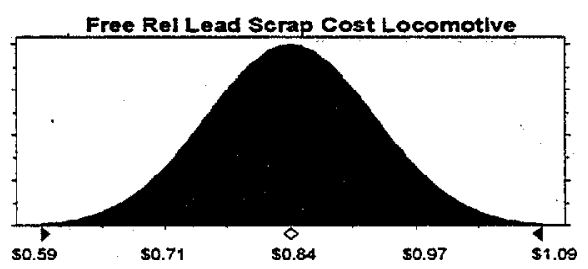

Selected range is from -Infinity to + Infinity 
Normal distribution with parameters:

Mean

Standard Dev.

Selected range is from - Infinity to + Infinity Mean value in simulation was $\$ 1.25$

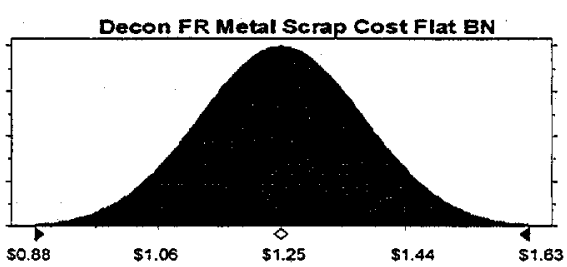

\section{Assumption: Decon FR Metal Scrap Cost Flat PX}

Normal distribution with parameters:

Mean

Standard Dev.

Selected range is from - Infinity to + Infinity Mean value in simulation was $\$ 1.25$

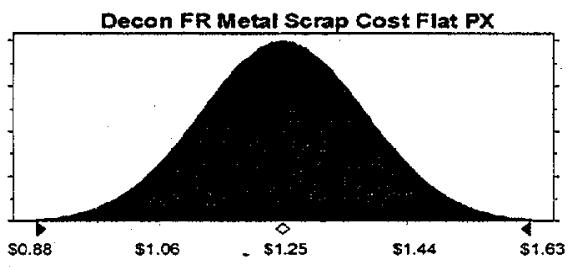

\section{Assumption: Decon FR Metal Scrap Cost Well 10B}

Normal distribution with parameters:

Mean

Standard Dev.

Selected range is from -Infinity to +Infinity Mean value in simulation was $\$ 1.25$

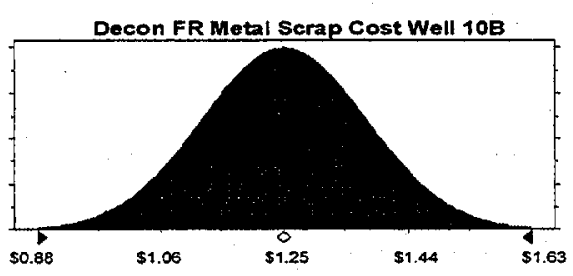

Cell: E29

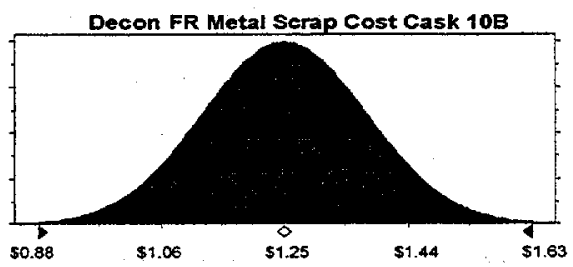

Selected range is from -Infinity to + Infinity

Mean

$\$ 0.13$

Mean value in simulation was $\$ 1.25$ 
Normal distribution with parameters:

Mean

Standard Dev.

$\$ 0.13$

Selected range is from - Infinity to + Infinity

Mean value in simulation was $\$ 1.25$

Assumption: Decon FR Metal Scrap Cost Tank 10A

Normal distribution with parameters:

Mean

Standard Dev.

Selected range is from - Infinity to + Infinity

Mean value in simulation was $\$ 1.25$

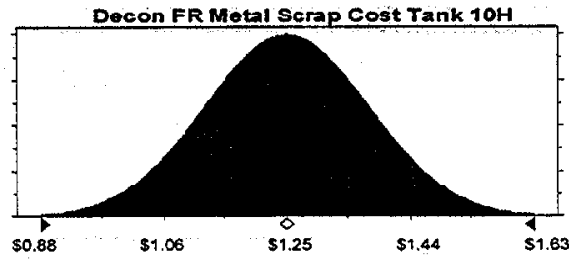

Cell: G29

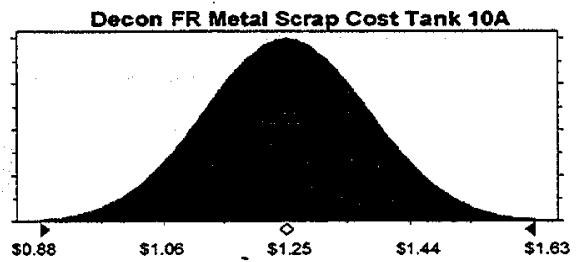

Cell: $\mathbf{H} 29$

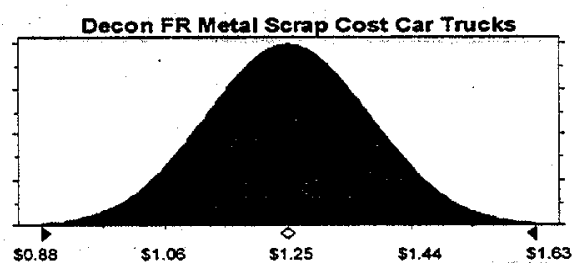

Cell: 129

Normal distribution with parameters:

$\$ 0.13$

Standard Dev.

Selected range is from -Infinity to + Infinity

Mean value in simulation was $\$ 1.25$

Selected range is from -Infinity to + Infinity Mean value in simulation was $\$ 1.25$

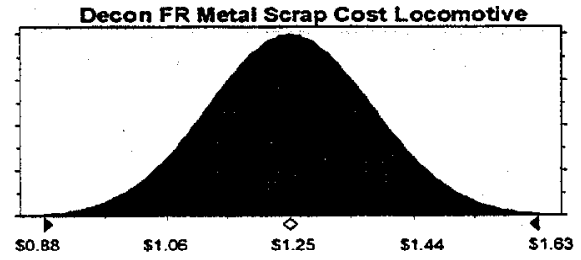


Triangular distribution with parameters:

Minimum

$\$ 1.40$

Likeliest

$\$ 1.65$

$\$ 1.75$

Selected range is from $\$ 1.40$ to $\$ 1.75$

Mean value in simulation was $\$ 1.60$
Maximum

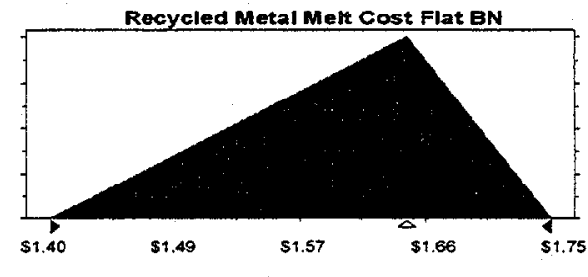

Cell: $\mathbf{C 3 1}$

$\$ 1.65$

$\$ 1.75$

Maximum

Selected range is from $\$ 1.40$ to $\$ 1.75$

Mean value in simulation was $\$ 1.60$
Triangular distribution with parameters:

Minimum

Likeliest

Maximum

Selected range is from $\$ 1.40$ to $\$ 1.75$

Mean value in simulation was $\$ 1.60$

\section{Assumption: Recycled Metal Melt Cost Cask 10B}

Triangular distribution with parameters:

Minimum

Likeliest

$\$ 1.65$

Maximum

$\$ 1.75$

Selected range is from $\$ 1.40$ to $\$ 1.75$ Mean value in simulation was $\$ 1.60$

\section{Cell: E31}

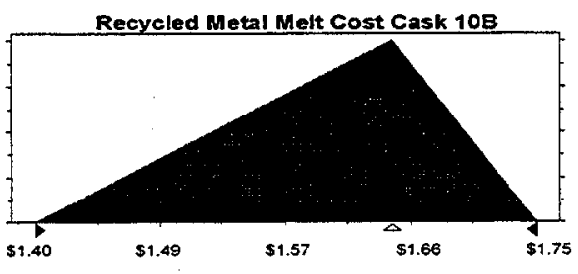


riangular distribution with parameters:

"Minimum

Likeliest

Maximum

$\$ 1.75$

elected range is from $\$ 1.40$ to $\$ 1.75$

lean value in simulation was $\$ 1.60$

uption: Recycled Metal Melt Cost Tank 10A

Triangular distribution with parameters: Minimum

Likeliest

$\$ 1.65$

Maximum

$\$ 1.75$

Selected range is from $\$ 1.40$ to $\$ 1.75$

Mean value in simulation was $\$ 1.60$

smption: Recycled Metal Melt Cost Car Trucks

Triangular distribution with parameters:

Minimum

Likeliest

Maximum

Selected range is from $\$ 1.40$ to $\$ 1.75$

Mean value in simulation was $\$ 1.60$

sumption: Recycled Metal Melt Cost Locomotive

Triangular distribution with parameters:

Minimum

$\$ 1.40$

Likeliest

$\$ 1.65$

Maximum

$\$ 1.75$

Selected range is from $\$ 1.40$ to $\$ 1.75$

Mean value in simulation was $\$ 1.60$

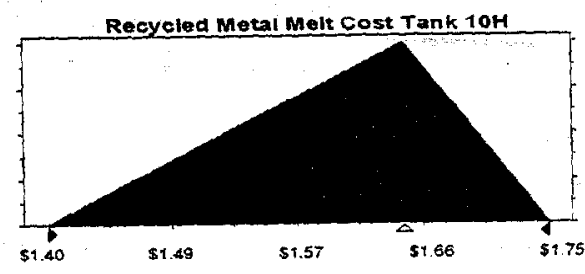

Cell: G31

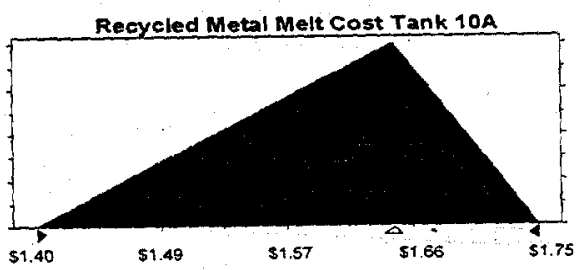

Cell: H31

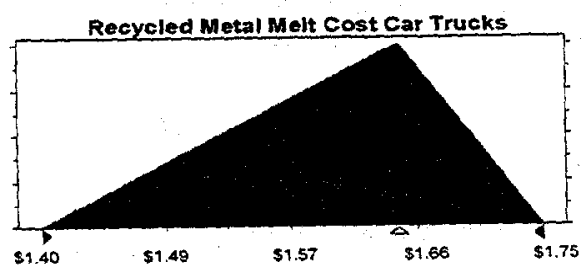

Cell: 131

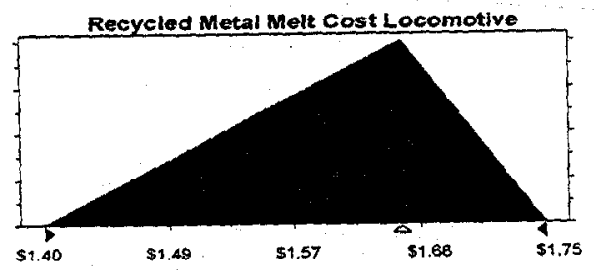


Uniform distribution with parameters: Minimum 0 Maximum 50

Mean value in simulation was 25

\section{Assumption: Cars Sent by CRO Locomotive}

Uniform distribution with parameters: Minimum 0 Maximum

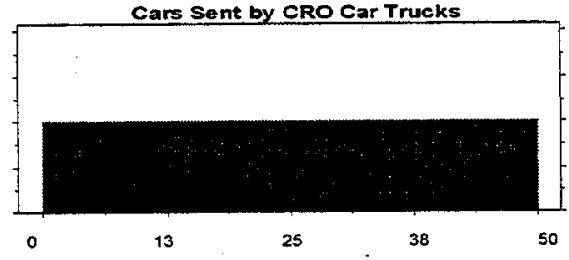

Cell: 136

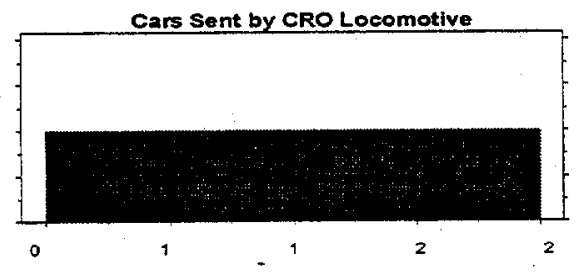

Cell: B39

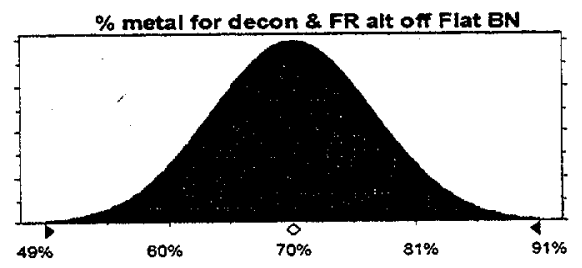

Cell: C39

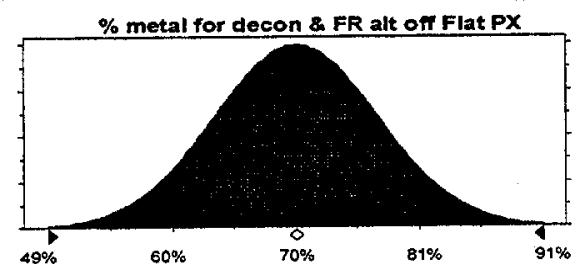

Selected range is from -Infinity to + Infinity

Mean value in simulation was $70 \%$

Mean

Standard Dev.

$70 \%$

$7 \%$

Selected range is from -Infinity to +Infinity Mean value in simulation was $70 \%$

Assumption: \% metal for decon \& FR alt off Flat PX

Normal distribution with parameters:
$70 \%$ $7 \%$

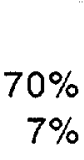

(1) 
Normal distribution with parameters:

Mean

$60 \%$

Standard Dev.

$6 \%$

Selected range is from -Infinity to + Infinity

Mean value in simulation was $60 \%$

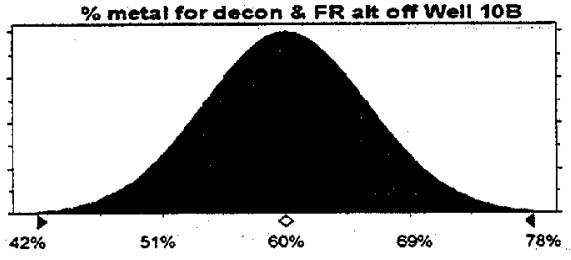

Cell: E39

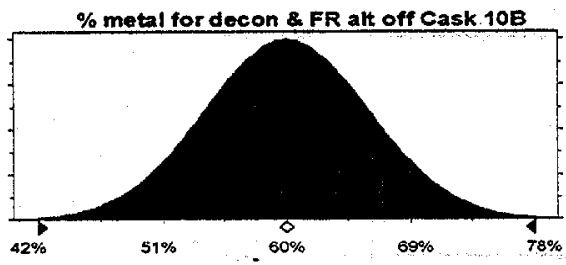

Cell: F39

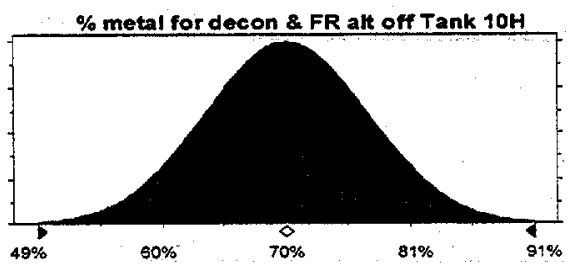

Cell: G39

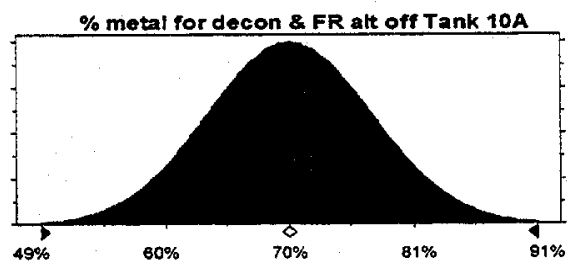

$81 \%$
Selected range is from -Infinity to + Infinity

Mean value in simulation was $70 \%$

$7 \%$

Selected range is from - Infinity to + Infinity

Mean value in simulation was $70 \%$

Normal distribution with parameters:

Mean

Standard Dev.

$70 \%$

$7 \%$
$70 \%$

$60 \%$

$6 \%$

Selected range is from -Infinity to +Infinity

Standard Dev. 
Normal distribution with parameters:

Mean

$70 \%$

Standard Dev.

Selected range is from -Infinity to + Infinity

Mean value in simulation was $70 \%$

Assumption: \% metal for decon \& FR alt off Locomotiv

Normal distribution with parameters:

Mean

Standard Dev.

$70 \%$

$7 \%$

Selected range is from -Infinity to + Infinity

Mean value in simulation was $70 \%$

Assumption: \% ret Metal for disp CRO option Flat BN

Triangular distribution with parameters:

Minimum

$5 \%$

Likeliest

$10 \%$

Maximum

$20 \%$

Selected range is from $5 \%$ to $20 \%$

Mean value in simulation was $12 \%$

\section{Assumption: Cars sent by CRO Flat BN}

Uniform distribution with parameters:

Minimum

Maximum

Mean value in simulation was 1

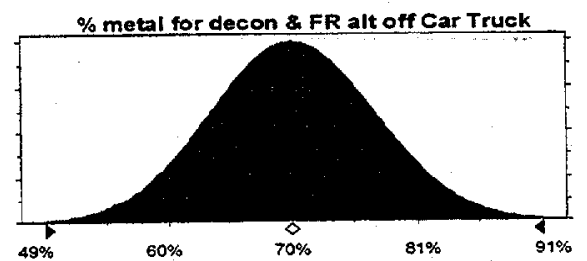

Cell: 139

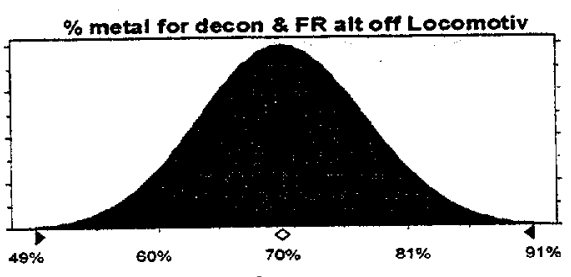

Cell: B46

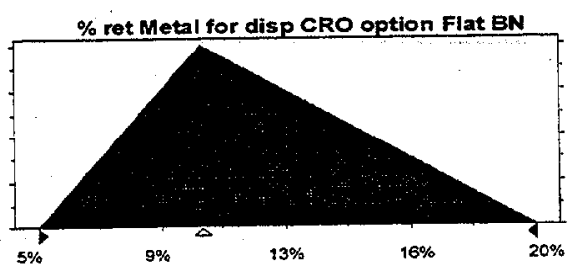

Cell: B36

Cars sent by CRO Flat BN

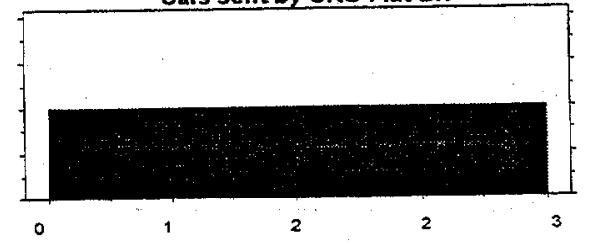


Assumption: Cars sent by CRO Flat PX

Cell: C36

Uniform distribution with parameters:

Minimum

Maximum

Mean value in simulation was 1

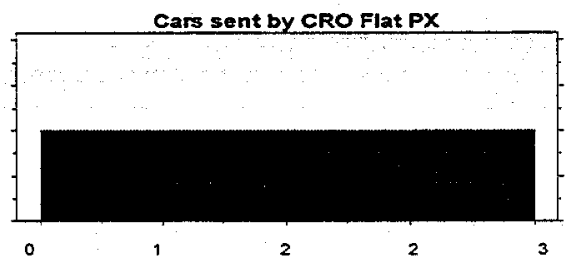

Assumption: \% ret Metal for disp CRO option Flat PX

Cell: C46

Triangular distribution with parameters:

Minimum

$5 \%$

Likeliest

$10 \%$

Maximum

$20 \%$

Selected range is from $5 \%$ to $20 \%$

Mean value in simulation was $12 \%$

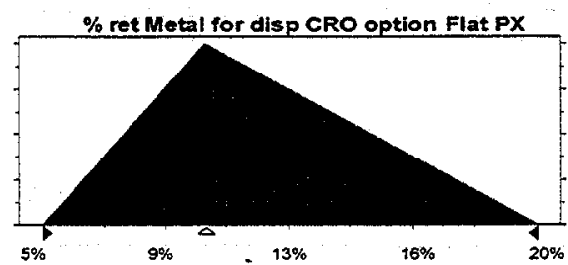

Assumption: $\%$ ret Metal for disp CRO option Well 10B

Cell: D46

Triangular distribution with parameters:

$\begin{array}{lr}\text { Minimum } & 5 \% \\ \text { Likeliest } & 10 \% \\ \text { Maximum } & 20 \%\end{array}$

Selected range is from $5 \%$ to $20 \%$

Mean value in simulation was $12 \%$

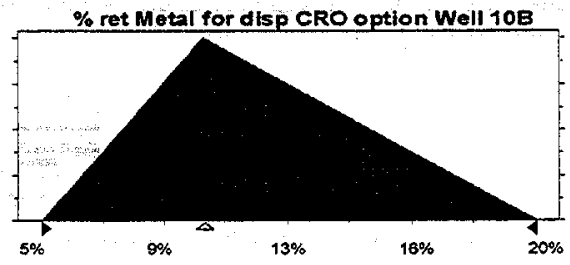

Assumption: \% ret Metal for disp CRO option Cask 10B

Cell: E46

Triangular distribution with parameters:

Minimum

$5 \%$

Likeliest

$10 \%$

Maximum

$20 \%$

Selected range is from $5 \%$ to $20 \%$

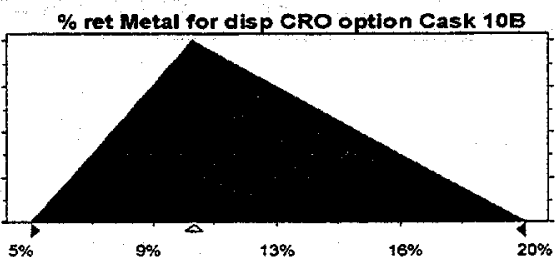

Mean value in simulation was $12 \%$ 
Triangular distribution with parameters:

$\begin{array}{lr}\text { Minimum } & 5 \% \\ \text { Likeliest } & 10 \% \\ \text { Maximum } & 20 \%\end{array}$

Maximum 20\%

Selected range is from $5 \%$ to $20 \%$

Mean value in simulation was $12 \%$

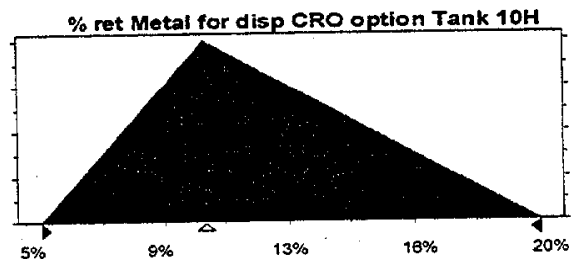

Assumption: \% ret Metal for disp CRO option Tank 10A

Cell: G46

Triangular distribution with parameters:

$\begin{array}{lr}\text { Minimum } & 5 \% \\ \text { Likeliest } & 10 \% \\ \text { Maximum } & 20 \%\end{array}$

Selected range is from $5 \%$ to $20 \%$

Mean value in simulation was $12 \%$

Assumption: \% ret Metal for disp CRO option Car Truc

Cell: $\mathrm{H} 46$

Triangular distribution with parameters:

$\begin{array}{lr}\text { Minimum } & 5 \% \\ \text { Likeliest } & 10 \% \\ \text { Maximum } & 20 \%\end{array}$

Selected range is from $5 \%$ to $20 \%$

Mean value in simulation was $12 \%$
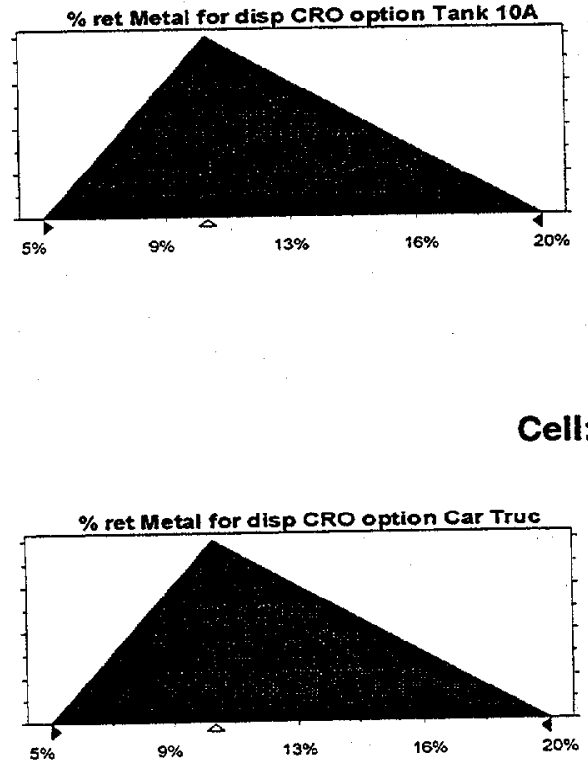

Assumption: \% ret Metal for disp CRO option Locomoti

Cell: 146

Triangular distribution with parameters:

Minimum

$5 \%$

Likeliest

$10 \%$

Maximum

$20 \%$

Selected range is from $5 \%$ to $20 \%$

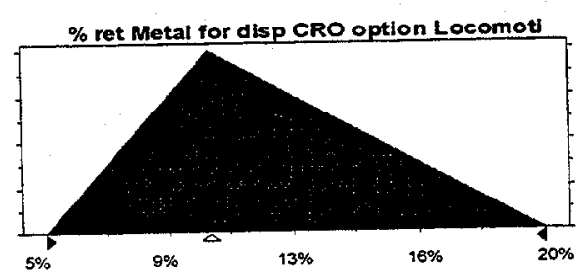

Mean value in simulation was $12 \%$ 
Assumption: Combo Cars sent to disposal on site Flat

Uniform distribution with parameters:

Minimum

0

Maximum

Mean value in simulation was 1

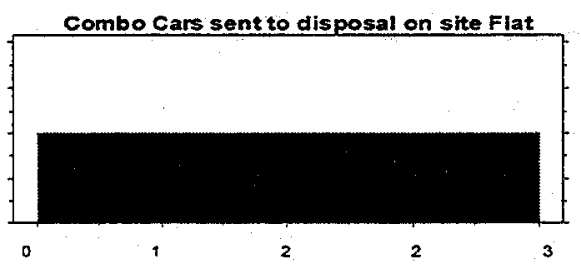

Assumption: Combo Cars sent to disposal on site Flat

Cell: $\mathbf{C 3 7}$

Uniform distribution with parameters:

Minimum

Maximum

Mean value in simulation was 1

Assumption: Combo Cars sent to disposal on site CT

Cell: H37

Uniform distribution with parameters:

Minimum

Maximum

Mean value in simulation was 25

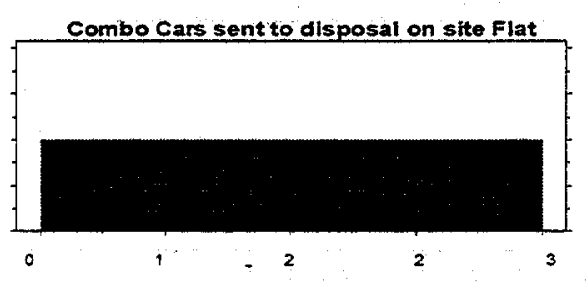

Assumption: Combo Cars sent to disposal on site Loco

Uniform distribution with parameters:

Minimum

0

Maximum

Mean value in simulation was 1

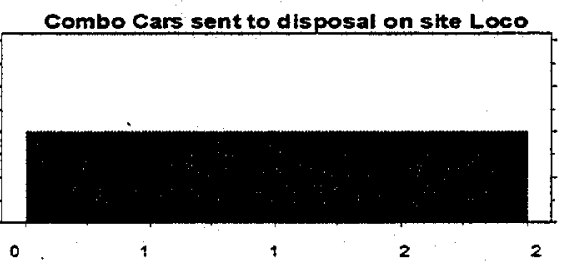


Uniform distribution with parameters: Minimum Maximum

Mean value in simulation was 0

Assumption: Cars sent by CRO Tank 10A

Uniform distribution with parameters: Minimum

Maximum

Mean value in simulation was 0

Assumption: Combo Cars sent to disposal on site Tank

Uniform distribution with parameters:

Minimum

Maximum

Mean value in simulation was 0

Assumption: Combo Cars sent to disposal on site Tank

Uniform distribution with parameters:

Minimum

Maximum

1

Mean value in simulation was 0

End of Assumptions

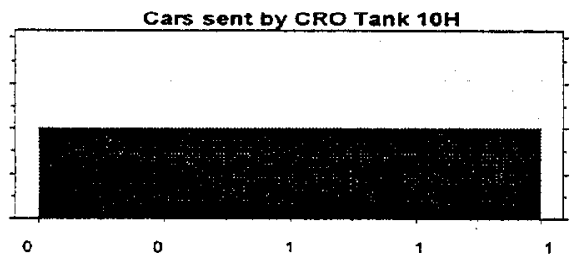

Cell: $\mathbf{G} 36$

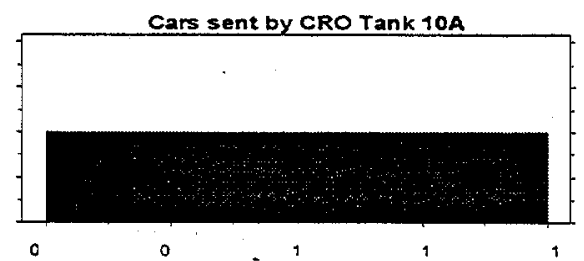

Cell: F37

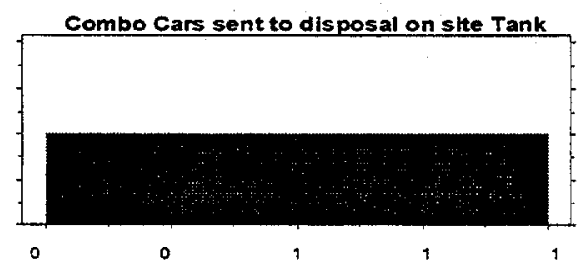

Cell: G37

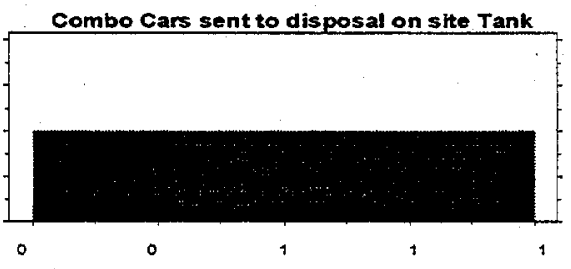




\section{Crystal Ball Report}

Simulation started on 10/21/99 at 9:08:13

Simulation stopped on 10/21/99 at 9:08:21

Forecast: Waste Vol Saved Cro Off-Site Vs Disposal

Cell: $\mathbf{G 3 6}$

Summary:

Certainty Level is $80.00 \%$

Certainty Range is from 1,767 to 1,948

Display Range is from 1,650 to 2,050

Entire Range is from 1,680 to 2,023

After 1,000 Trials, the Std. Error of the Mean is 2

Statistics:

Trials

$\underline{\text { Value }}$

Mean

1000

Median

1,856

Mode

1,856

Standard Deviation

Variance

Skewness

4,531

Kurtosis

0.01

Coeff. of Variability

2.41

Range Minimum

0.04

Range Maximum

1,680

Range Width

2,023

Mean Std. Error

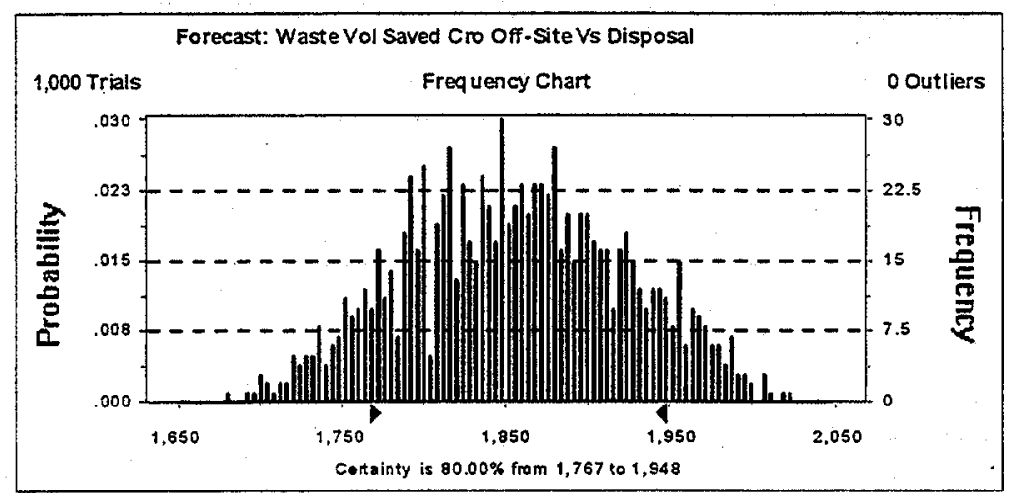


Forecast: Waste Vol Saved Cro Off-Site Vs Disposal (cont'd)

Cell: G36

Percentiles:

\begin{tabular}{r} 
Percentile \\
\hline $0 \%$ \\
$10 \%$ \\
$20 \%$ \\
$30 \%$ \\
$40 \%$ \\
$50 \%$ \\
$60 \%$ \\
$70 \%$ \\
$80 \%$ \\
$90 \%$ \\
$100 \%$
\end{tabular}

$\underline{\text { Value }}$

1,680

1,766

1,794

1,816

1,838

1,856

1,874

1,893

1,917

1,947

2,023

End of Forecast 


\section{Assumptions}

Assumption: Disposal 1A

Cell: B28

Uniform distribution with parameters:

Minimum

132,012

Maximum

145,213

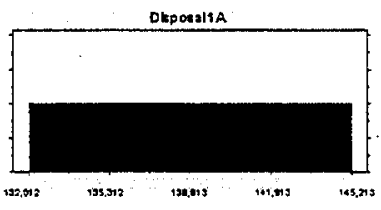

Mean value in simulation was 138,789

Assumption: MW

Cell: $\mathbf{C 2 8}$

Uniform distribution with parameters:

Minimum

4,728

Maximum

5,201

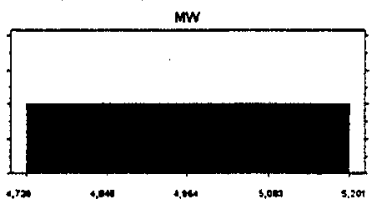

Mean value in simulation was 4,965

Assumption: Combination CRO \& Off--Site Vendor

Cell: B31

Uniform distribution with parameters:

Minimum

6,600

Maximum

26,402

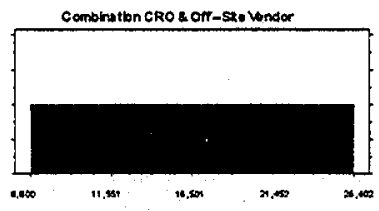

Mean value in simulation was 16,135

Assumption: C31

Cell: C31

Uniform distribution with parameters:

Minimum

Maximum

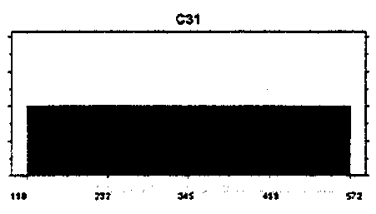

Mean value in simulation was 349

End of Assumptions 
8

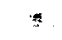

,

n 


\title{
INTERNAL DISTRIBUTION
}

\author{
1-30. K. L. Yuracko \\ 31. Laboratory Records-RC \\ 42. Central Research Library \\ 42-43. Office of Scientific and Technical Information
}




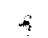

" 